UNIVERSIDADE DE SÃO PAULO

FACULDADE DE EDUCAÇÃO

CARLOS EDUARDO DAMIAN LEITE

A virtualidade na mediação simbólica e na linguagem sob o ponto de vista docente na aprendizagem

São Paulo

2011 


\section{A virtualidade na mediação simbólica e na linguagem sob o ponto de vista docente na aprendizagem}

Dissertação apresentada à Faculdade de Educação da Universidade de São Paulo, para a obtenção do título de Mestre em Educação.

Área de Concentração: Linguagem e Educação.

Orientador: Prof. ${ }^{\text {a }}$ Dr. ${ }^{a}$ Nilce da Silva.

São Paulo 
Autorizo a reprodução e divulgação total ou parcial deste trabalho, por qualquer meio convencional ou eletrônico, para fins de estudo e pesquisa, desde que citada a fonte.

Catalogação na Publicação

Serviço de Biblioteca e Documentação

Faculdade de Educação da Universidade de São Paulo

371.36 Leite, Carlos Eduardo Damian

L533v A virtualidade na mediação simbólica e na linguagem sob o ponto de vista docente na aprendizagem / Carlos Eduardo Damian Leite; orientação Nilce da Silva. São Paulo: s.n., 2011.

102 p.: il.

Dissertação (Mestrado - Programa de Pós-Graduação em Educação. Área de Concentração: Linguagem e Educação) - Faculdade de Educação da Universidade de São Paulo.

1. Novas tecnologias da comunicação - Educação 2. Educação - Recursos visuais 3. Criatividade 4. Linguagem I. Silva, Nilce da, orient. 
Nome: LEITE, Carlos Eduardo Damian.

Título: A virtualidade na mediação simbólica e na linguagem sob o ponto de vista docente na aprendizagem

Dissertação apresentada à Faculdade de Educação da Universidade de São Paulo, para a obtenção do título de Mestre em Educação.

Aprovado em:

\section{Banca Examinadora}

Prof. Dr. Instituição:

Julgamento: Assinatura:

Prof. Dr. Instituição:

Julgamento: Assinatura:

Prof. Dr. Instituição:

Julgamento: Assinatura: 
À minha querida Sofia, com amor e gratidão por todo o carinho, por toda a luta, compreensão e presença, ao longo da realização desta pesquisa, e de tantos outros eventos que ocorreram a ela paralelamente. 


\section{AGRADECIMENTOS}

Agradeço primeiramente a Deus, mestre espiritual e estrategista cósmico de todas as façanhas físicas e metafísicas, por ser um guia e uma fortaleza nos momentos de angústia e desesperança. Foram muitos os obstáculos encontrados e ultrapassados, e muitas as conquistas obtidas, para que o caminho fosse trilhado em um verdadeiro processo de aprendizagem. Não é significativo apenas o Mestrado em si, mas também todos os eventos que ocorreram antes da seleção de mestrandos, durante minha estadia em São Paulo, para estudar e trabalhar, tendo um primeiro e íntimo contato com a maior cidade do país, e nesta reta final, residindo em Ubatuba, no litoral norte, e concluindo mais uma etapa em minha formação acadêmica em meio às descobertas, conflitos e sabores da vida a dois.

Meu agradecimento especial é para a pessoa a quem dedico esta dissertação, minha amada e querida Sofia Lara Todão Szenczi, companheira de todas as horas, apoio, carinho e conforto para os momentos mais desesperadores. É também a base dialética de minha vida, que me faz pensar constantemente sobre quem sou, o que desejo, o que possuo e a que almejo, em todos os âmbitos. Muitas vezes é motivo de alguns contratempos, mas que fazem parte desta dinâmica da convivência, e como é prazeroso demonstrar meus sentimentos mesmo nestes instantes de abalos e incertezas. Agradeço também à sua família, que contribuiu e muito para que minha linda se tornasse a pessoa maravilhosa que é!

Agradeço e muito à minha orientadora, Prof. ${ }^{a}$ Nilce da Silva, por todos os momentos em que me aconselhou sobre minha atuação no Mestrado, por demonstrar total interesse para com o tema pesquisado e por toda a compreensão e paciência para com meus momentos de insegurança e de bloqueio criativo e textual - que, com toda certeza, não foram poucos! Agradeço também ao auxílio do Prof. Emerson de Pietri, que orientou a elaboração do questionário qualitativo utilizado, e também demonstrou muito interesse para com o tema de minha dissertação.

Obrigado também à minha família, em especial a minha avó materna Arlete. Sua fé, paciência e carinho ensinam-me a confiar mais em mim mesmo e no amanhã, e motivam-me a aprender cada vez mais, em todos os momentos de minha vida. 
$O$ historiador e o poeta não se distinguem um do outro pelo fato de o primeiro escrever em prosa e o segundo em verso. Diferem entre si, porque um escreveu o que aconteceu e o outro o que poderia ter acontecido. 
LEITE, C. E. D. A virtualidade na mediação simbólica e na linguagem sob o ponto de vista docente na aprendizagem. 2011. 102 f. Dissertação (Mestrado) - Faculdade de Educação, Universidade de São Paulo, São Paulo, 2011.

\section{RESUMO}

Na concepção docente, o virtual possui apenas uma face, reconhecível por meio do que é visto, elaborado e/ou modificado nas telas dos computadores e demais recursos digitais de tecnologia. Esta pesquisa teve como objeto a virtualidade em suas duas instâncias: a humana, que se faz presente nas projeções que integram o processo de imaginação e criação, em potência e ato; e a sua vertente nas novas tecnologias, em um ambiente digital, denominado virtual, por permitir a visualização e interação com as diversas possibilidades criativas do indivíduo. Teve como objetivos analisar a concepção contemporânea sobre o virtual, principalmente do ponto de vista docente, pesquisar sobre as duas formas pelas quais o virtual se faz presente nas realizações humanas e ,ainda, analisar, por meio de um estudo de caso, quais são as ideias que o professor possui em relação ao virtual e em seu uso em âmbito pedagógico. A hipótese deste trabalho se constitui na afirmação de que o virtual possui duas vertentes, ambas relevantes ao desenvolvimento humano - a inerente às capacidades mentais do homem e a que se manifesta por meio das tecnologias digitais. Como metodologia de pesquisa, realizou-se um estudo de caso, com abordagens quantitativa e qualitativa, cujos propósitos foram pesquisar conceitos específicos sobre o tema e realizar uma análise sobre o ponto de vista docente para com o virtual, em um determinado contexto: a Escola Municipal Governador Mário Covas Júnior, em Ubatuba, cidade localizada no litoral norte de São Paulo. Foram utilizados na coleta de dados um questionário quantitativo, para sondagem do uso docente das novas tecnologias, e outro com questões abertas, para que fossem coletadas as concepções dos professores da instituição sobre o virtual nas atividades escolares. Constatou-se que a ênfase do professor ainda está voltada para a presença do virtual em sua segunda instância, a das novas tecnologias. Por meio de uma explanação, que constituiu a intervenção do pesquisador no estudo de caso, outras concepções do virtual foram transmitidas, concluindo-se que a partir destas, pode ser inicialmente estimulada a compreensão do professor para com a virtualidade humana.

\section{PALAVRAS-CHAVE}

Virtualidade, simbólico, novas tecnologias, criatividade, linguagem. 
LEITE, C. E. D. The virtuality in symbolic mediation and language from the teaching point of view in learning. 2011. 102 f. Dissertação (Mestrado) - Faculdade de Educação, Universidade de São Paulo, São Paulo, 2011.

\begin{abstract}
In teaching concept, the virtual has only one face, recognizable by what is seen, written and / or modified on the screens of computers and other digital resources of technology. This research had as its object the virtuality in two instances: the human, which is present in the projections that cover the process of imagination and creation in power and act, and his part in the new technologies in a digital environment, called virtual allow for the visualization and interaction with various creative possibilities of the individual. Aimed to analyze the contemporary concept of the virtual, especially from the standpoint of teaching, research about the two ways in which the virtual is present in human achievement and also examine, through a case study, what are the ideas that the teacher has over the virtual connection and its use in teaching. The hypothesis of this thesis is the claim that the virtual is twofold, both relevant to human development - the inherent mental capacities of man and that manifests itself by means of digital technologies. As a research methodology, there was a case study with quantitative and qualitative approaches, whose purpose was to investigate specific concepts on the subject and do an analysis on the point of view toward virtual teacher in a certain context: the School Municipal Governor Mario Covas Junior in Ubatuba, Sao Paulo. Were used to collect the data, a quantitative questionnaire to survey the use of new teaching technologies, and other open questions, that would be collected from teachers' conceptions of the institution on the virtual school activities. It was found that the emphasis of the teacher is still focused on the virtual presence in your second instance, the new technologies. Through an explanation, which was the researcher's intervention in the case study, other concepts were transmitted from the virtual, concluding that from these may be initially stimulated understanding of the teacher toward the virtual human.
\end{abstract}

\title{
KEYWORDS
}

Virtuality, symbolic, new technologies, creativity, language. 
1.1 O Jogo como Base da Virtualidade Humana na Mediação Simbólica ........... 13

1.2 As Manifestações da Virtualidade em suas Diversidades e Complexidades .. $\quad 21$

1.3 A Percepção das Informações como Base da Virtualidade ............................. 26

1.4 A Inteligência Coletiva como Noosfera de Virtualidade ................................... 29

2. APLICAÇÃO PEDAGÓgICA DA VIRTUALIDAdE NAS NOVAS TECNOLOGIAS COMO INOVAÇÃO EDUCACIONAL

2.1 Do Cognitivo à Gestão do Conhecimento

2.2 A Função do Lúdico na Educação e o Ensino à Distância

2.3 O Professor e as Novas Tecnologias no Desenvolvimento do Saber .

2.4 O Virtual na Subjetivação dos Jogos Eletrônicos

2.5 Projeções para o Futuro da Educação no Brasil

CAPÍTULO II - A REALIDADE DO PONTO DE VISTA DOCENTE: ESTUDO DE CASO NA ESCOLA MUNICIPAL GOVERNADOR MÁRIO COVAS JÚNIOR

3. INTRODUÇÃO AO ESTUDO DE CASO

3.1 Definições de Estudo de Caso

3.2 Reflexões acerca das Ideologias de José Pacheco e a Escola da Ponte

3.3 A Idealização de uma Parceria Pedagógica: Escola da Ponte e E. M. Governador Mário Covas Júnior

4. O ESTUDO DE CASO: A ESCOLA MUNICIPAL GOVERNADOR MÁRIO COVAS JÚNIOR

4.1 Descrição da Escola Municipal Governador Mário Covas Júnior

4.2 Apresentação e Análise do Questionário de Dados Quantitativos

4.3 Apresentação e Análise do Questionário de Questões Abertas

APÊNDICE A 


\section{INTRODUÇÃO}

Esta dissertação foi dividida em dois capítulos, que repartem o texto em um primeiro momento, no qual se apresentou a definição de virtualidade, baseando-se nas concepções de Aristóteles (1979) e Pierre Lévy $(1993,1996)$, que conduzem à determinação de duas instâncias para a manifestação do virtual: a humana (baseada na imaginação e criatividade) e a tecnológica (presente nos recursos digitais). Diante da discussão destas concepções e a determinação do que vem a ser virtual, foi em um segundo momento analisada uma instituição escolar específica, como um estudo de caso, a fim de que fossem colhidos dados que comprovassem a importância de se trabalhar com a virtualidade nas duas instâncias citadas, em meio às realizações promovidas pelos docentes sujeitos da pesquisa.

O objeto de pesquisa é, portanto, a virtualidade em suas duas manifestações, sendo que os objetivos deste trabalho consistiram em analisar a concepção contemporânea sobre o virtual, principalmente do ponto de vista docente, já que aparentemente se mantém restrito ao ambiente virtual das novas tecnologias, e pesquisar sobre as duas formas pelas quais o virtual se faz presente nas realizações humanas - seja por manifestações exclusivamente mentais, a criatividade e a imaginação, ou mesmo pela extensão das mesmas, proporcionada pela realidade virtual -; e ainda analisar, por meio de um estudo de caso, como se efetivam as ideias que o professor possui para com as manifestações do virtual, e como as mesmas podem ser devidamente trabalhadas com seus alunos.

A tentativa de verificar as duas vertentes do virtual - a inerente às capacidades mentais do homem e a que se manifesta por meio das tecnologias digitais - constitui a hipótese deste trabalho. A hipótese foi baseada na premissa de que o professor deve reconhecer em seus alunos a importância do virtual não apenas com a utilização das novas tecnologias, mas também por meio das capacidades mentais de criação e imaginação. Assim, o docente seria capaz de desenvolver em seus alunos a verdadeira concepção de virtualidade. Em relação a este cenário, surge uma problematização para com o modo pelo qual os professores buscam estimular as capacidades de seus educandos: em meio a tantos recursos tecnológicos, a educação ainda é desenvolvida de forma padronizada, sem a devida exploração da criatividade e do autoaprendizado, acompanhado de um raciocínio crítico.

O questionamento advindo da problematização desta realidade foi: é possível modificar o ponto de vista docente sobre de que maneira a verdadeira virtualidade pode ser desenvolvida, como forma de complementação da mente humana para com as novas tecnologias? Com tal 
questão, buscou-se focar o problema pesquisado na falta de se utilizar um aprendizado multimídia, no qual o virtual, enquanto capacidade humana, corresponda à virtualização da realidade nas novas tecnologias e vice-versa.

Deste modo, a hipótese deste trabalho foi baseada em Lévy (1996) sobre o ambiente virtual enquanto extensão da imaginação cuja afirmação é de que a complementaridade seria fundamental na ação docente para o desenvolvimento da virtualidade de seus educandos. Se o processo de imaginar e criar antes se resumia à representação mental, transmitida apenas pela fala, agora o virtual é "materializado" em um local específico, graças às tecnologias digitais. Isto possibilita que a criatividade e imaginação, devidamente trabalhadas e geradas pelo domínio da linguagem, possam ter seus produtos representados de forma semelhante ou igual, como uma projeção mental do próprio autor, por meio do ambiente virtual.

Como metodologia de pesquisa empregada no estudo de caso desta dissertação, a fim de constatar-se em uma instituição escolar específica o desejo de se explorar contextos criativos nas atividades do cotidiano, e se estas teriam destaque, pelo menos, igual ao das demais realizações curriculares - incluindo o uso das novas tecnologias -, realizou-se um trabalho exploratório, com abordagem qualitativa, cujos propósitos foram adquirir familiaridade com o tema e desenvolvêlo sobre um determinado contexto. Este contexto foi abordado na Escola Municipal Governador Mário Covas Júnior, em Ubatuba, cidade localizada no litoral norte do estado de São Paulo.

A escolha da escola deve-se justamente à relação que possui com a inclusão digital de seus alunos, uma vez que é equipada com um dos melhores laboratórios de informática dentre as escolas de Ensino Fundamental I do município, segundo Projeto Político Pedagógico da instituição, do ano de 2009, e dados específicos da Secretaria Estadual de Educação. Por meio de dois questionários, sendo um deles uma sondagem quantitativa e o outro com questões abertas, foi avaliada com os professores a concepção que os mesmos possuem para com a virtualidade, tanto em suas funções como para com o processo de ensino-aprendizagem.

Ao fim do ano de 2010, a escola iniciou um contato com José Pacheco - idealizador do contexto pedagógico e sociocultural da Escola Básica Integrada Aves/São Tomé de Negrelos, conhecida popularmente como Escola da Ponte, em Portugal -, a fim de expandir as concepções de seus gestores e professores em relação às atividades que estimulem o lúdico de maneira efetiva, constituindo deste modo um passo fundamental para a compreensão do que vem a ser o desenvolvimento da virtualidade junto aos educandos.

O primeiro capítulo da dissertação apresenta teóricos, além de Aristóteles (1979) e Pierre Lévy $(1993,1996)$, que fundamentam outras questões relacionadas à virtualidade, tanto em suas 
manifestações - na mente humana e nas tecnologias digitais - como em sua função sociocultural. Dentre os autores que fundamentaram esta primeira parte da pesquisa, Aristóteles (1979) é colocado como o primeiro a reconhecer a capacidade virtual do ser humano, com concepções em torno dos vícios e virtudes, bem como desta ser uma ferramenta importante na visualização do indivíduo para com suas realizações futuras, isto é, suas potencialidades, o que poderia vir a ser.

Tais ideias sobre o potencial humano são explicitadas apenas no início, mas servem de base para todo o texto, inclusive quando se discute o potencial das novas tecnologias para a educação. Neste ponto, as ideias de Pierre Lévy $(1993,1996)$ vão ao encontro das de Aristóteles, pois o virtual humano estende-se para meios exteriores ao próprio homem, por meio do conhecimento divulgado, discutido e reelaborado pelas tecnologias digitais e pela Internet, inclusive materializando-se por meio do ambiente - ou realidade - virtual.

A finalidade desta pesquisa tem sido a de esclarecer a respeito da importância do virtual enquanto elemento presente na capacidade humana de planejar e antever as potencialidades de seus pensamentos e atitudes, tudo isso em plano mental, sem que seja necessariamente efetivado. O segundo capítulo vem reafirmar tais discussões com dados levantados na prática. A coleta de dados, realizada por meio da sondagem e do questionário qualitativo com os professores da E. M. Governador Mário Covas Júnior, demonstrou que as concepções sobre a virtualidade estão restritas ao que pode ser verificado no ambiente virtual, sem que seja considerada a capacidade mental, inerente ao ser humano, de criar e imaginar.

O que pôde ser averiguado, por meio das realizações desta pesquisa - que incluiu o levantamento das concepções teóricas sobre virtualidade, a aplicação do questionário com questões abertas e a explanação sobre o virtual ao corpo docente do estudo de caso -, e que será devidamente apontado e discutido no capítulo dois, é que o ponto de vista docente deve ser estimulado para reconhecer não apenas o potencial dos educandos em realizações diversificadas e multimídias, por meio das tecnologias digitais, mas também é fundamental que o professor desenvolva a virtualidade de seus alunos por meio da criatividade e imaginação, aliadas à compreensão e domínio da linguagem como meio de propagação de ideias. 


\section{CAPÍTULO I - CONSIDERAÇÕES SOBRE O VIRTUAL}

“Ao imergir no ambiente virtual, colocamos lá dentro a nossa representação. Um signo de nós mesmos. Tornamonos metáforas".

(Delmar Galisi, 2003).

"Imaginação é tudo, é a prévia das atrações futuras"

(Albert Einstein).

\section{ABORDAGEM TEÓRICA SOBRE A VIRTUALIDADE}

\subsection{O Jogo como Base da Virtualidade Humana na Mediação Simbólica}

por viver muitos anos dentro do mato moda ave o menino pegou um olhar de pássaro contraiu visão fontana. por forma que ele enxergava as coisas por igual como os pássaros enxergam. as coisas todas inominadas. água não era ainda a palavra água. pedra não era ainda a palavra pedra. e tal. as palavras eram livres de gramáticas e podiam ficar em qualquer posição. por forma que o menino podia inaugurar. podia dar às pedras costumes de flor. podia dar ao canto formato de sol. e, se quisesse caber em uma abelha, era só abrir a palavra abelha e entrar dentro dela. como se fosse infância da língua.

(Rupestre - Projeto Axial)

A pesquisa realizada na Escola Municipal Governador Mário Covas Júnior durante o ano de 2010, sobre a importância que a virtualidade possui para com a prática docente, procurou destacar como o professor pode explorar a criatividade em meio aos recursos pedagógicos do cotidiano. Tratou de analisar a virtualidade, sem que o foco de tal análise fosse voltado apenas ao 
termo "virtual", junto de seu significado em meio ao uso das novas tecnologias, mas sim à oposição que é determinada ao se contrapor o que é virtual em relação ao que é real.

Portanto, a virtualidade foi considerada neste trabalho uma oposição à realidade, destacando-se ainda as possibilidades do real ser complementado pelo virtual, e este de potencializar aquele, em meio ao contexto psicossocial e educacional. Por isto, discutir a virtualidade é um aspecto importante, em relação às possibilidades que se apresentam ao docente, quando este associa o poder de criação da mente humana às novas tecnologias. Tais possibilidades serão analisadas para com a Escola Municipal Mário Covas, paralelamente à adoção desta instituição em relação às concepções pertinentes à pedagogia adotada na Escola da Ponte.

A virtualidade, segundo Aristóteles (1979) e Lévy (1993, 1996), possui duas vertentes diferenciadas: uma pertencente às capacidades da mente humana, no que diz respeito à imaginação e criatividade, bem como a utilização destas no processo de mediação e representação simbólica do mundo. A segunda vertente diz respeito à sua manifestação por meio das novas tecnologias, que se faz verificável pelos sentidos e por isso mesmo pode ser considerada uma espécie de materialização da primeira, possibilitada pela chamada realidade ou ambiente - virtual.

Ambas as manifestações do virtual possuem relação com a realidade, sendo que a primeira, que se manifesta por meio da imaginação humana, diferencia-se da segunda, presente nos recursos cibernéticos (WIENER, 1971), já que esta possibilita a visualização em grupo do que antes era apenas individual. Assim sendo, as possibilidades de que sejam fomentadas mais discussões, relacionadas ao planejamento de algo que ainda não foi atualizado, aumentam à medida que mais pessoas podem ter uma noção prévia do que foi idealizado, por meio do ambiente virtual e, com isso, discorrerem juntas em torno das diversas e potenciais realizações.

Para que sejam consideradas e analisadas as atividades dos professores do $1 .^{\circ}$ ao $5 .^{\circ}$ ano da instituição analisada, correspondentes aos conteúdos gerais de linguagem (Língua Portuguesa), cálculo (Matemática) e conhecimento histórico (Histórico), espacial (Geografia) e científico (Ciências), serão a elas associadas as características e o verdadeiro potencial da virtualidade em relação à mente humana, nos âmbitos individual e coletivo. Deve-se primeiro considerar a formação da cultura humana a partir de elementos lúdicos, pertencentes à natureza do jogo, tais como o uso de regras específicas e determinadas, além do ato de interpretar o meio ambiente a partir de símbolos adotados por uma convenção social, gerando novos valores em um processo de re-significação. Tal afirmação é ressaltada, em meio ao estudo de caso em que se 
baseou esta dissertação, dentre as premissas e valores destacados nas concepções pedagógicas da instituição analisada.

$\mathrm{Na}$ medida em que este trabalho abordou a virtualidade efetivada pela imaginação humana, e esta, por sua vez, forma-se por meio de aspectos socioculturais, como a linguagem e o simbólico, fez-se mister o uso da obra de L. S. Vygotsky (2001), pois o autor aponta como características de seu terceiro pressuposto, o sociointeracionista ${ }^{1}$, a adoção do simbólico na interpretação da realidade e na apreensão de informações, capacidade humana possível apenas graças à plasticidade do cérebro (propriedade que lhe permite a adaptação em relação ao meio e ao conhecimento constantemente apreendido e inovado).

A partir do momento em que tais interpretações simbólicas são reunidas e utilizadas como um conjunto de combinações, surge a linguagem, dentro de um sistema linguístico específico, de acordo com particularidades de cunho sociocultural. Tal colocação ganha importância, inclusive, quando a linguagem é valorizada pelo professor sujeito deste trabalho, como elemento base do desenvolvimento do educando, considerando-se aqui os dados coletados por meio do questionário aplicado aos docentes da instituição de estudo de caso, conforme relato do segundo capítulo.

Dentro da concepção de Saussure (ORLANDI, 1999), a linguagem se basearia em aspectos distintos na relação simbólica entre homem e mundo, denominados de acordo com os aspectos analisados no desenvolvimento deste processo. Diante das questões apontadas, o foco pode ser voltado para o que vem a ser considerado a dicotomia principal do autor: o significado (objeto a ser nomeado) e o significante (denominação simbólica dada ao objeto), que compõem os chamados signos linguísticos.

Tal conceito auxilia na compreensão do processo de nominação dos objetos e a tradução da realidade em símbolos. São variados e complexos os elementos que geram e complementam a cultura humana, desde as descobertas primitivas sobre os objetos, seres e fenômenos do mundo até a contemporânea era da informação. Elementos em comum podem ser identificados entre o desenvolvimento da cultura humana e a apreensão das informações, mesmo com tantas diferenças encontradas nas sociedades ao longo dos séculos, analisando-se suas realizações políticas, econômicas e socioculturais.

A interpretação humana do mundo por meio dos símbolos, junto da criatividade e imaginação, efetiva um ciclo psicossocial na mente humana, enquanto manifestação das

\footnotetext{
${ }^{1} \mathrm{O}$ primeiro pressuposto de Vygotsky seria o inatismo, pelo qual o biológico limita e determina o desenvolvimento, e o segundo o ambientalismo, que desconsidera a base biológica na relação humana com o ambiente (2001).
} 
capacidades físicas e mentais dos seres humanos de forma lúdica, que possibilita a identificação, apreensão e representação de ideias e conceitos de um mesmo modo atemporal para os seres humanos. Segundo Vygotsky (2001), o ciclo psicossocial se inicia pela observação, o primeiro contato com o objeto, ser ou fenômeno analisado, seguido ou não de uma experimentação, um teste, na tentativa de se descobrir uma reação ou mesmo função do que é estudado.

Ainda segundo o mesmo autor (2001), a partir das características observadas e das experiências obtidas, as informações apreendidas no mundo, em objetos, seres e fenômenos da natureza, são adaptadas para a representação simbólica, por meio da qual o que é estudado ganha uma denominação específica, para que sejam reconhecidos pelos demais seres humanos. Com os conteúdos simbólicos agrupados e organizados, surge a linguagem, com a qual o homem pode apreender e transmitir informações sobre ele mesmo, sobre outros e sobre seu meio, de maneira diferenciada.

Por meio deste processo de apreensão de informações, é desenvolvida uma capacidade inerente aos seres humanos, que será inclusive o objeto desta pesquisa: a virtualidade, com foco no modo pelo qual ela é elemento inerente ao processo de mediação simbólica do mundo e de apreensão das informações.

Segundo Aristóteles (1979), o ser humano desenvolve a capacidade de ser virtual à medida que lida com as representações simbólicas, exclusivamente em um plano mental, utilizando-se de uma ludicidade com suas próprias crenças, ideias e valores, na criação de concepções que, não necessariamente, existem no mundo com o qual realiza contato diário. Ou seja, por meio da virtualização, a experiência humana com um objeto, ser ou fenômeno, ou ainda com conceitos relacionados aos mesmos, não precisa sequer existir naturalmente, para que seja efetivada, ou mesmo, aceita como algo possível ou indubitável.

Sabe-se que um dos principais objetivos da educação é estimular o desenvolvimento pleno do aluno, nos âmbitos pessoal, intelectual e psicossocial. Dentre os elementos pertencentes a este desenvolvimento seria, segundo a premissa de Aristóteles (1979), o virtual. A partir destas considerações, propõe-se como objeto de estudo desta dissertação a virtualidade, com foco no modo pelo qual ela se faz presente no processo de apreensão, interpretação e representação do mundo, bem como do processo de ensino aprendizagem dos indivíduos, seguido de uma abordagem específica, relacionada ao ponto de vista docente sobre a virtualidade de seus alunos, em meio ao processo de ensino e aprendizagem.

A virtualidade está presente não apenas na imaginação e criatividade, enquanto elementos gerados na mente e fidedignos apenas à representação da mesma, como também nas 
possibilidades que as novas tecnologias oferecem para o desenvolvimento do indivíduo, tanto no mundo real como no digital. Cabe ao professor entender que os estímulos devem ser variados, para que a compreensão da natureza humana entre em equilíbrio com a valorização das tecnologias digitais para a transmissão e questionamento de saberes.

Segundo Lévy (1993), quando a palavra virtual - que inclusive se torna um "lugar comum", vista sua utilização constante - é empregada no meio educacional, logo seus profissionais a relacionam com o ambiente virtual, inerente à utilização das novas tecnologias e à apreensão de informações por meio de textos e recursos desenvolvidos por quem se utiliza da rede mundial de redes de computadores. Esquecem-se, portanto, do significado primeiro a que o virtual está relacionado, ignorando assim as possibilidades educacionais a partir do reconhecimento e aprimoramento, por parte dos alunos, da própria criatividade e imaginação como recursos virtuais de aprendizado e desenvolvimento intelectual e pessoal.

Da união de um objeto a um nome (ou do significante a um significado) surge o símbolo e o signo linguístico - representação mental e /ou gráfica do real, junto da sonoridade que o equivale -, que além de traduzirem a realidade na cultura humana, por meio da linguagem, permitem a intervenção humana por meio do jogo, para a reinvenção dos significados, a partir de novos olhares sobre o significante (VYGOTSKY, 2001).

Conforme se constatou durante a coleta de dados e a análise da instituição em questão, tal concepção de mediação simbólica faz-se fundamental para que o profissional docente perceba e compreenda como a virtualidade está presente em suas realizações e de seus educandos, por meio das atividades desenvolvidas e que podem vir a ser aplicadas no cotidiano escolar. No caso desta dissertação, discorre-se aqui especificamente das questões criativas que envolvem as atividades dos professores da instituição analisada, inclusive quando são considerados os elementos adotados a partir da pedagogia promovida pela Escola da Ponte.

Tal parâmetro realizado entre o lúdico e a linguagem talvez traga a interpretação incorreta de que o jogo surge como elemento $d a$ cultura humana, quando na verdade o mais adequado é que se discuta, em relação ao ser humano, sobre a presença do lúdico na sua atividade cultural. Ou seja, na medida em que este trabalho abordou o modo como o simbólico e a virtualidade se reúnem de forma lúdica, em meio à imaginação humana, criando formas variadas de representação e interação da realidade, recorreu-se a um clássico da área: J. Huizinga.

Segundo Huizinga (2000), o jogo se faz presente em diversos contextos culturais, inclusive no que diz respeito às culturas anteriores à humana, como em ações específicas do reino animal, tais como a "dança" promovida por abelhas e disputas reais - pela liderança do 
grupo ou por comida, feita por animais adultos - ou encenadas - no caso das brincadeiras feitas por filhotes.

De acordo com Huizinga (2000), faz-se importante salientar características importantes do lúdico, que podem ser observadas neste último exemplo de jogo, a encenação de uma disputa dentre os animais. Há todo um conjunto de regras que se impõe aos participantes ou jogadores pois não há jogo se não há a concordância entre as partes -, assim como é fundamental que haja o envolvimento - já que o processo lúdico somente possui continuidade caso aqueles que jogam mantiverem-se concentrados em suas ações - como também a diversão -, fator que gera o envolvimento de maneira espontânea, tendo como fator complementar o prazer, a satisfação de jogar. Para Huizinga (2000), esta seria a fonte da existência do jogo e motivação da realização lúdica pelo ambiente como um todo.

No âmbito da mente humana, pode-se afirmar, segundo a compreensão do lúdico por parte de Huizinga (2000), que a interpretação e representação do mundo por meio do simbólico se efetiva como que em um clima de jogo, ou ainda, de brincadeira. Joga-se - ou brinca-se, mentalmente - com objetos, seres, fenômenos e significados, para que nessa dinâmica seja gerada e formalizada a linguagem, com todo um conjunto de palavras que a integram, diferenciadas a partir de um determinado contexto cultural, e utilizadas devido a uma mesma necessidade: a de se transmitir informações, de um modo inteligível, único e eficaz.

Se para Huizinga (2000) a diversão é um fator emocional, que satisfaz o jogador e o mantém como centro das realizações lúdicas, motivando-o inclusive a jogar novamente e dar continuidade ao processo entre a ludicidade como causa, e o prazer como consequência, para Csikszentmihalyi (1999) o resultado é na verdade o que ele denomina como "fluxo": um fator psicossocial mantém envolvido e concentrado aquele que joga, como se o mesmo estivesse em uma busca por novos significados e potencialidades para com o próprio e seu meio.

Em meio às diversas realizações do contexto atual, o ser humano se envolve em atividades lúdicas variadas. O indivíduo deixa-se, em suas ações e pensamentos, envolver por elementos próprios da experiência lúdica, mas que o influenciam de maneira única, devido às questões socioculturais que o envolvem desde o nascimento. Segundo Csikszentmihalyi (1999), o ato de jogar é caracterizado pela transformação do tempo - a percepção cronológica modificase de acordo com o envolvimento - uma tarefa desafiadora que requeira habilidade específica, mescla entre ação e consciência, objetivos claros e recompensas imediatas, ausência do senso de perda de controle sobre a situação, com concentração exclusiva na tarefa realizada. 
Dentro da concepção de jogo pode-se considerar a presença da virtualidade, a partir da potencialidade humana e dos atos decorrentes desta. Para Aristóteles (1979), os objetos, seres e fenômenos existem e efetivam sua existência no mundo em potência e ato. Algo é ou está em potência quando sua situação se resume em um "vir-a-ser", como uma semente é ou está uma árvore, considerando-se tal estado potencialmente. Algo que é ou está em ato já está atualizado/realizado, como uma árvore é a atualização ou realização de uma semente em ato. É interessante notar que todos os elementos existentes, mesmo em ato, também o são em potência; pois uma árvore - uma semente em ato -, também é uma folha de papel ou uma mesa em potência.

A importância desta afirmação fica clara no desenvolvimento do capítulo dois, conforme são analisadas as concepções docentes de potência e ato, a fim de que fosse analisada a virtualidade no processo de ensino e aprendizagem, bem como a ideia dos professores da referida escola, a partir dos dados coletados na instituição de estudo de caso desta pesquisa. Questões estas de suma importância para esta pesquisa, pois a mesma abordou a necessidade do estímulo criativo voltado aos alunos, e a maneira como pode ser realizado de modo constante, a fim de que o educando crie possibilidades de análise de seu próprio ambiente.

Aristóteles (1979) identifica o ato sem qualquer potencialidade, existente como totalmente em ato, com a concepção de "Ato Puro", comparado pelo filósofo com a idéia do que vem a ser o Bem. Esse Ato não é nada em potência, nem é a realização de potência alguma. Ele é sempre igual a si mesmo, e não é um antecedente de coisa alguma. Desse conceito Tomás de Aquino derivou sua noção de Deus, em que Ele seria "Ato Puro". Um ser em potência só pode tornar-se um ser em ato, mediante algum movimento. O movimento vai sempre da potência ao ato, da privação à posse. É por isso que o movimento pode ser definido como ato virtual de um ser enquanto está em potência. $\mathrm{O}$ ato é, portanto, a realização da potência, e essa realização pode ocorrer por meio da ação, gerada pela potência ativa, e perfeição, gerada pela potência passiva.

Todos estes conceitos demonstram que a noção de virtualidade possui complexidade e valoração anteriores às tecnologias digitais, podendo-se considerar que o virtual não existiria, ou ao menos não seria passível de realização, se não fossem as potencialidades mentais humanas, fazendo do objeto de pesquisa deste trabalho a virtualidade, com foco no modo pelo qual ela se faz presente no processo de apreensão, interpretação e representação do mundo, bem como do processo de ensino aprendizagem dos indivíduos, seguido de uma abordagem específica, direcionada ao ponto de vista docente sobre a virtualidade de seus alunos, em meio ao processo de ensino e aprendizagem. 
Pelo ato de imaginar e criar em sua mente símbolos, representações para si mesmo e para o mundo, o ser humano é capaz de se projetar no tempo e espaço, garantindo sua efetivação enquanto ser virtual, a partir de pensamentos que podem se tornar ações, a partir da potência que pode vir a ser ato. Estes pensamentos também foram destacados na intervenção do autor para com o estudo de caso em questão. A partir destas considerações, pôde-se constatar nesta pesquisa que a relação humana com o universo simbólico - que no contexto desta investigação foi considerado para a manifestação da virtualidade em sua primeira instância - se realiza dentro de questões que envolvem todo um contexto do jogo, enquanto fenômeno sociocultural. São utilizadas, afinal, pelo ser humano, regras específicas no ato de interpretação de seu meio, relacionando-se os objetos a suas aparências e funções primárias, com isso criando diversas vezes os nomes e funções adjacentes.

Com isso, o mundo no contexto do homem é povoado pelo simbólico, gerando e renovando a cada redescoberta deste sobre aquele, toda a base de significantes e significados dos diversos sistemas linguísticos, combinados com sua imaginação e criatividade para a geração de elementos primordiais em sua cultura. De acordo com Eliade (1991), o pensamento simbólico pode ser considerado como algo consubstancial ao homem, devido à sua importância diante da existência e evolução psicossocial e cultural dele, precedendo a linguagem e a razão discursiva. "O símbolo revela certos aspectos da realidade - os mais profundos - que desafia qualquer outro meio de conhecimento" (ELIADE, 1991, p. 08).

Os símbolos trariam, em uma ação independente do tempo e espaço, as marcas de pensamentos e interpretações anteriores, refletindo-se no modo de pensar do homem contemporâneo, juntando-se às suas atribuições de mundo para a manutenção de uma realidade psíquica - tendo nas mitologias a representação mais significativa deste processo. A partir da ideia de aluno enquanto ser simbólico, a concepção de virtualidade sob o ponto de vista docente torna-se mais claro, à proporção que o professor compreende que ambos podem unir imagem e ação nas atividades que permeiam o processo de ensino e aprendizagem, tal como observado na coleta de dados, focando-se a importância da criatividade em meio ao uso dos recursos tecnológicos, para que o educando venha a ser estimulado em sua imaginação e capacidade de interagir com o ambiente de maneira lúdica.

Tal necessidade destacou-se nas concepções pedagógicas que a escola visa a adotar, a partir das discussões fomentadas por José Pacheco em ocasiões diversas (vide segundo capítulo). Tendo constatado que a virtualidade manifesta-se na mente humana, por meio da imaginação, e que o uso do universo simbólico faz com que seja alimentada de maneira diversa, por meio da 
criatividade, e que ainda o que existe em potencial pode ser agora demonstrado por meio das novas tecnologias, antes de se tornar realidade, há de se tratar das contribuições das manifestações do virtual para com os aspectos socioculturais da sociedade.

\subsection{As Manifestações da Virtualidade em suas Diversidades e Complexidades}

A virtualidade, segundo Aristóteles (1979) destaca-se como elemento presente na cultura humana, muito antes das novas tecnologias digitais, de acordo com os preceitos teóricos analisados até este ponto. O virtual deve ser, principalmente, compreendido enquanto elemento inerente ao ser humano, como recurso gerado por sua mente, a partir da criatividade e imaginação, ambas sendo utilizadas dentro dos significados que são elaborados a partir da interpretação simbólica do homem para com seu meio. Para tanto, faz-se necessário não apenas analisar o modo como o simbólico passa a fazer parte da cultura humana, inclusive no processo de criação e desenvolvimento da linguagem, como também compreender o modo como o cognitivo opera em meio a este processo de produção e assimilação de informações sobre o mundo.

$\mathrm{Na}$ manifestação da virtualidade em relação à vertente humana, foi analisada anteriormente a relação lúdica que o homem estabelece com o mundo, por meio da criatividade e imaginação, desenvolvendo a representação simbólica para assimilar e compreender a função de objetos e características de seres e fenômenos. Dentre as manifestações do simbólico na cultura humana, destacam-se a linguagem, com suas especificidades culturais, e outras manifestações específicas, como a mitologia e o ritual.

Em relação à cultura humana, não há manifestação mais coerente entre o lúdico e o simbólico do que as mitologias e os rituais oriundos destas. Ainda com a dessacralização do ser humano contemporâneo - que inclui a perda de ritos fundamentais e os conteúdos pertinentes à vida espiritual - as matrizes da imaginação não foram rompidas, tampouco o interesse por mitos e símbolos, que podem integrar um possível retorno à espiritualidade humana, recompondo aspectos essenciais a ela. A pesquisa vem ao encontro deste interesse humano latente por explorar as possibilidades acerca do simbólico, o que no contexto educacional, voltado para a instituição analisada como o estudo de caso em que se baseou esta dissertação, pôde apresentar elementos pertinentes às realizações dos professores sujeitos desta análise. 
Para uma realização plena da compreensão dos elementos que caracterizam a apreensão de informações por meio do virtual, deve-se considerar este elemento como de base lúdica, ou seja, formado por características que possuem base no jogo. O lúdico apresenta-se como um fenômeno base para com a cultura dos animais e dos homens: o jogo caracteriza todos os elementos a elas pertencentes. Portanto, como destaca Huizinga (2000), é importante utilizar-se o artigo "da" ao invés de "na”, pois este não é um elemento pertencente, mas formador da cultura humana.

Segundo o mesmo autor, o jogo seria anterior e superior à cultura, porém não se reduz a um simples instinto: "O jogo é fato mais antigo que a cultura, pois esta, mesmo em suas definições menos rigorosas, pressupõe sempre a sociedade humana (...)". (2000, p. 03) Os animais possuem atividades lúdicas anteriores às dos homens, mas reduzidas pela momentaneidade, algo produzido para saciar uma necessidade finita, o que caracterizam suas atividades em geral.

Pode-se considerar a cultura humana, como na colocação de Schaff:

(...) como a totalidade dos produtos materiais e espirituais do homem em um período determinado e em uma determinada nação (cultura nacional) ou, no sentido mais amplo, abarcando a totalidade do gênero humano (cultura universal), ou enfim no sentido de uma parte isolada da humanidade em escala supranacional (...) (1993, p. 72).

Apesar do lúdico na cultura dos animais ser anterior, há de se considerar a maior complexidade do jogo nas atividades humanas, graças às propriedades exclusivas do cérebro humano. Nele se destacam a plasticidade - qualidade do que é plástico, que pode ser moldado pela ação de elementos externos - e a mediação simbólica - modo pelo qual é mediada a relação do homem com o mundo (2001).

Morin faz considerações relevantes no que diz respeito ao chamado "circuito cérebro/mente/cultura":

O homem somente se realiza plenamente como ser pela cultura e na cultura. Não há cultura sem cérebro humano (...) mas não há mente, isto é, capacidade de consciência e pensamento, sem cultura. A mente humana é uma criação que emerge e se afirma na relação cérebro-cultura. Com o surgimento da mente, ela intervém no funcionamento cerebral e retroage sobre ele. Há, portanto, uma tríade em circuito entre cérebro/mente/cultura, em que cada um dos termos é necessário ao outro. A mente é o surgimento do cérebro que suscita a cultura, que não existiria sem o cérebro (2001, p. 52-53). 
Ao longo do desenvolvimento individual e de sua espécie, o ser humano tem se mostrado capaz de moldar seu cérebro de acordo com novas funções, criadas ao longo de sua história. O órgão, portanto, mostra-se não como um sistema de funções fixas e imutáveis, mas como um "sistema aberto", de uma plasticidade essencial, dadas as possibilidades de realização da mente humana. (VYGOTSKY, 2001, p. 24)

A característica da plasticidade demonstra ser fundamental para que a natureza ganhe um segundo significado na mente humana, a partir dos símbolos. Sua compreensão também ganha valor, para que se possa compreender as possibilidades que o corpo docente da instituição analisada possui, ao aplicar a premissa da virtualidade em suas realizações. $\mathrm{O}$ sistema aberto pelo qual se caracteriza o cérebro permite uma flexibilidade, tanto no que diz respeito à quantidade como à qualidade, assim como o tipo de conhecimento que se assimila. Para o processo que se refere ao reconhecimento e à efetivação de sua virtualidade, de acordo com os preceitos aristotélicos do homem virtuoso (ARISTÓTELES, 1979), esta capacidade de criar e inovar sempre é essencial.

Dentre as realizações do homem perante o mundo, tem-se a adaptação do cérebro humano para com a mediação simbólica, dentro do já analisado terceiro pressuposto vygotskiano, para se compreender o fundamento sócio-histórico do funcionamento psicológico: “a relação do homem com o mundo não é uma relação direta, mas uma relação mediada, sendo os sistemas simbólicos os intermediários entre o sujeito e o mundo" (VYGOTSKY, 2001, p. 24).

Partindo disto, Vygotsky classifica os mediadores em instrumentos e signos, sendo a partir destes dois artifícios construída a relação do ser humano com seu ambiente de maneira lúdica: em um processo de caráter histórico-cultural, o homem utiliza o jogo tanto para fabricar elementos que se interponham entre ele e o trabalho, "ampliando as possibilidades de transformação da natureza" (2001, p. 30), quanto para criar representações mentais dos objetos do mundo real.

A manifestação lúdica entre os seres vivos apresenta-se como um fenômeno com um fim em si mesmo, distanciado da vida cotidiana, possuindo tempo e espaço previamente determinados, com normas a serem obedecidas, dentro da maior seriedade. Nem por isso um jogo precisa necessariamente ser sério: o divertimento é uma das características principais dele, tornando-o interessante, prazeroso.

Vale salientar que o jogo em si não gera o vício: este é gerado pelas emoções projetadas nele pelos jogadores. As atividades lúdicas estão além dos valores morais de bem e mal, justo e injusto. Além do mais, a liberdade se apresenta como inerente à diversão. Afinal, qualquer jogo 
que seja realizado de maneira forçada deixa imediatamente de proporcionar prazer. Assim, outra característica fundamental do jogo é "o fato de ser livre, de ser ele próprio liberdade." (HUIZINGA, 2000, p. 04)

A diversão é essencial não só para que o jogo mantenha-se fiel ao seu conceito original, mas para que sua função nas atividades da cultura humana possa surtir os efeitos desejados, incluindo o de ferramenta de aprendizado. Vygotsky, cujo conceito de faz-de-conta corresponde ao de jogo simbólico estudado por Piaget (2003), afirma que:

(...) numa situação imaginária como a da brincadeira de 'faz-de-conta', (...) a criança é levada a agir num mundo imaginário, (...) onde a situação é definida pelo significado estabelecido pela brincadeira e não pelos elementos reais concretamente presentes (...). $\mathrm{O}$ que na vida real é natural e passa despercebido, na brincadeira torna-se regra e contribui para que a criança entenda o universo particular dos diversos papéis que desempenha. No brinquedo a criança comporta-se de forma mais avançada do que nas atividades da vida real e também aprende a separar objeto e significado. (VYGOTSKY, 2001, p. 32)

Como dito anteriormente, o jogo possui tempo e espaço próprios, além de ser inerente à liberdade e à diversão. Contra a argumentação de que crianças e animais não possuem a consciência de que estão jogando, de que são levados pelo instinto ou pela necessidade de desenvolver as faculdades físicas e seletivas, Huizinga aponta que:

(...) o termo 'instinto' levanta uma incógnita e (...) a pressuposição inicial da utilidade do jogo constitui uma petição de princípio. As crianças e os animais brincam porque gostam de brincar, e é precisamente em tal fato que reside sua liberdade (2000, p. 10).

Portanto, o jogo vai muito além de uma necessidade de simular as atividades do cotidiano para o aprendizado, ou um modo de ocupar os momentos de ócio. A finalidade a que obedece é "exterior aos interesses materiais imediatos e à satisfação individual das necessidades biológicas" (HUIZINGA, 2000, p. 12). Por isso, mesmo possuindo o elemento tensão ligado ao divertimento, o jogo não possui uma função de descarga das energias em excesso. Na verdade, em sua "qualidade de atividade sagrada, o jogo naturalmente contribui para a prosperidade do grupo social, mas de outro modo e através de meios totalmente diferentes (...)” (idem).

O jogo possui seu começo e seu fim, e é nesse tempo reservado que se transmite sua importância aos jogadores. Mas, "mesmo depois de o jogo ter chegado ao fim, ele permanece como uma criação nova do espírito, um tesouro a ser conservado pela memória. É transmitido, 
torna-se tradição" (HUIZINGA, 2000, p. 12-13). O jogo e o virtual podem ser considerados inerentes e complementares entre si, pois ambos caracterizam-se por meio de um elemento específico, que permite serem desenvolvidos de acordo com o limite da plasticidade cerebral, o que por sua vez exige que o cérebro esteja em constante movimento de adaptação.

A virtualidade, especificamente, conduz o homem neste processo a não apenas elaborar novos significados para o mundo que o cerca, a partir dos símbolos, mas também a jogar, a brincar com os mesmos, empregando-os de maneira diferente em relação a objetos, seres e fenômenos variados, em momentos inusitados, de acordo com a própria criatividade. Diante do valor que possuem o jogo e a criação nas realizações humanas, torna-se primordial a compreensão destes elementos, assim como a função dos mesmos no cotidiano escolar, conforme se constatou na coleta de dados.

As práticas simbólicas acabam por gerar todo um significado do mundo para o ser humano (VYGOTSKY, 2001), que a partir deles exerce sua produção de conhecimento sobre o mundo, utilizando-se da imaginação e criatividade, obtendo criações das mais diversas nas áreas da linguagem, do cálculo, de sua historicidade e espacialidade, bem como do domínio científico - o que inclui as tecnologias pelas quais as ações humanas são aperfeiçoadas e o progresso sociocultural obtido (LÉVY, 1993). Eis, portanto, a função do jogo na cultura humana, e a virtualidade como modo exclusivo do homem exercer sua ludicidade.

À medida que o homem gera sua linguagem e com ela determina os significados que o mundo possui, em diferentes contextos histórico-culturais, faz-se mister esta compreensão para que fosse analisado o contexto específico dos educadores da escola Mário Covas. Os professores desta instituição, tomada como estudo de caso desta dissertação, atuam com crianças do $1 .^{\circ}$ ao $5^{\circ}$ ano. Nestes períodos escolares, além do estímulo da identidade e autonomia dos educandos (FREIRE, 2002), os conteúdos a eles ministrados apresentam possibilidades diferentes, desde que seja considerado o processo que conduz o ser humano à exploração de sua virtualidade, principalmente, no que diz respeito ao estudo contínuo de sua linguagem.

Deste modo, tratar-se-á a seguir de como o ser humano apreende informações, destacando-se as características lúdicas do processo, e também como a virtualidade serve de base para que os conteúdos sejam manipulados e organizados, conforme a subjetividade dos sujeitos que as processam. Assim sendo, tais concepções vão ao encontro das discussões acerca da prática escolar analisada a partir do estudo de caso desta dissertação, para que se compreenda a importância da criatividade no processo de ensino e aprendizagem. 
Tal ação será fundamental para que se compreenda o modo pelo qual os docentes podem interagir com seus educandos, promovendo para com os mesmos a curiosidade e, a partir dela a criatividade, quando na formulação de respostas é necessário que se construa uma opinião, baseada nos conteúdos pré-assimilados. Também será verificado se, após a iniciativa de adotar a ideologia da Escola da Ponte, tais práticas se efetivaram como estímulo ao virtual dos educandos.

\subsection{A Percepção das Informações como Base da Virtualidade}

Após a discussão inicial sobre a virtualidade como processo mental, que ocorre quando o ser humano assimila o mundo por meio do simbólico e que, a partir deste, cria a linguagem formada por um conjunto de códigos e regras específicos, de acordo com o contexto histórico e sociocultural -, verificou-se também que ele tem a possibilidade de exercer no virtual uma criatividade ilimitada, por meio da capacidade de planejar as próprias ações ou o próprio discurso, antes que o mesmo se torne real/atual. Sendo assim, cabe neste momento a análise de como as informações são percebidas e apreendidas pelo ser humano, na compreensão inicial deste processo da virtualidade, para que se possa discutir os dados coletados em campo.

A abordagem de Vygotsky sobre a percepção está centrada no fato desta, ao longo do desenvolvimento humano, tornar-se cada vez mais complexa, ao distanciar-se das determinações fisiológicas dos órgãos sensoriais sem excluir de vez as possibilidades dos órgãos físicos (2001, p. 73). Processos psicológicos superiores e a mediação simbólica seriam os pressupostos iniciais para a explicação desse fenômeno essencialmente cultural, apresentados como elementos norteadores, inclusive, das concepções pedagógicas da instituição analisada.

Neste sentido, a apreensão de informações possui o simbólico como base, e a virtualidade como uma capacidade inerente à mente humana, que norteia o processo de criação, e a partir do mesmo se efetiva a realização do que foi pensado. O sistema sensorial humano define, com suas próprias limitações, as características da percepção de informações do indivíduo. Através da internalização da linguagem, dos conceitos e dos significados desenvolvidos culturalmente, a percepção deixa de ser uma relação direta entre o homem e o meio, passando a ser mediada pelos conteúdos culturais.

Este ciclo de apreender e processar o mundo por meio de códigos específicos, de acordo com a sociedade e sua cultura, pode ser compreendido na prática docente como a forma pela qual 
se pode estimular o pensamento criativo por parte do aluno, desde que seja respeitada sua individualidade. Diante da análise das atividades promovidas pelos professores da instituição de estudo de caso, serão consideradas estas premissas.

A Teoria da Gestalt, em suas análises estruturais, desenvolveu conceitos para definir o modo como o ser humano capta, apreende idéias e imagens (MÜLLER-GRANZOTTO, 2007). A essência da teoria é transmitida por meio de seis premissas básicas, na tentativa de expor o processo pelo qual a informação é apreendida. Pode-se entender, a partir do processo de apreensão, o processo de devolução dos dados, o feedback - que por sua vez depende da complexidade dos dados iniciais e da quantidade informacional devidamente apreendida e compreendida.

Se for considerada a atuação docente, e em específico as realizações dos professores da Escola Municipal Mário Covas, também serão discutidas a importância do devido retorno dos alunos em relação aos conteúdos transmitidos, e se puderam expressar sua subjetividade em meio às atividades escolares. As premissas da Gestalt também são fundamentais na compreensão do corpo docente da aplicação do virtual nas atividades propostas aos alunos, bem como nas próprias realizações, de acordo com a análise da instituição escolhida como estudo de caso desta dissertação.

As seis premissas básicas da Gestalt são a semelhança (ou "similaridade"), a proximidade, a boa continuidade, a pregnância, a clausura (ou "fechamento"), a experiência passada. A semelhança define que os objetos similares tendem a se agrupar. A similaridade pode acontecer na cor dos objetos, na textura e na sensação de massa dos elementos. Quanto à proximidade, os elementos são agrupados de acordo com a distância a que se encontram uns dos outros. Logicamente, elementos que estão mais perto de outros numa região tendem a ser percebidos como um grupo, mais do que se estiverem distante de seus similares (MÜLLERGRANZOTTO, 2007, p. 12).

A boa continuidade está relacionada à coincidência de direções, ou alinhamento, das formas dispostas. Isso facilita a compreensão e os elementos harmônicos tendem a produzir um conjunto harmônico. A pregnância aponta que as formas tendem a ser percebidas em seu caráter mais simples, a exemplo de uma espada e um escudo, que podem ser retratados por meio de uma reta e um círculo. É o princípio da simplificação natural da percepção. Quanto mais simples, mais facilmente será assimilada: desta forma, a parte mais facilmente compreendida em um desenho é a mais regular, que requer menos simplificação. 
A clausura é o princípio de que a boa forma se completa, se fecha sobre si mesma, formando uma figura delimitada. O conceito de clausura relaciona-se ao fechamento visual, como se um objeto incompleto fosse visualmente completado. Ocorre geralmente quando o desenho do elemento sugere alguma extensão lógica. O conceito de boa continuidade está ligado ao alinhamento, pois dois elementos alinhados passam a impressão de estarem relacionados (MÜLLER-GRANZOTTO, 2007, p. 14).

A experiência passada, que via nas associações o processo fundamental da percepção da forma, relaciona-se com o chamado pensamento pré-Gestaltico. A associação é imprescindível, pois certas formas só podem ser compreendidas se já são conhecidas, ou se houver a consciência prévia de sua existência. Da mesma forma, a experiência passada favorece a compreensão metonímica: ao ser visualizada uma parte de um elemento, este pode ser reproduzido na memória em sua forma completa (idem).

Em meio a tais premissas da Teoria da Gestalt, considera-se que a virtualidade permite também a manipulação de todos os conteúdos armazenados na mente humana, seja no reconhecimento de objetos, seres e fenômenos, por exemplo, seja pela semelhança, por pregnância ou por experiências passadas. O profissional docente tem a possibilidade de estimular tal capacidade, reconhecendo o valor que o subjetivo, por meio da imaginação, possui neste processo, deixando que a criança haja com criatividade mostrando, sobre aquilo que lhe é proposto, uma solução que se utilize de sua percepção individual sobre seu ambiente.

Diante dos elementos da percepção, pode-se perceber que o contato do homem com seu mundo, além de ser mediado pela própria cultura simbólica, não se dá por meio de atributos físicos isolados, mas em termos de objetos, eventos e situações rotulados pela linguagem. A atenção se torna voluntária e conseqüência da percepção à medida que, ao longo do desenvolvimento, o ser humano passa a ser capaz de dirigi-la, voluntariamente, para elementos do ambiente que ele tenha definido como relevantes; afirmação esta que se faz clara, diante da seleção que é constantemente realizada no processo de ensino e aprendizagem.

A relevância dos objetos da ação voluntária, de acordo com Vygotsky, está relacionada à atividade desenvolvida e ao seu significado, "sendo construída ao longo do desenvolvimento do indivíduo em interação com o meio em que vive” (2001, p. 75). A seleção das informações, portanto, é feita de acordo com a relevância individual e o contexto cultural de cada ser, buscando para tanto o melhor meio de se obter os dados que lhe dizem respeito.

Assim sendo, cabe ao professor a possibilidade de selecionar conteúdos que sejam relevantes à individualidade do aluno, bem como ao contexto histórico e sociocultural do grupo 
em sua totalidade, promovendo deste modo, a assimilação do simbólico. O que é fundamental para que, com base no virtual, as discussões e demais atividades pedagógicas recebam respostas dentre as mais variadas possíveis, e que neste processo haja a busca natural por aquilo que, na realidade, possa parecer improvável, mas que na virtualidade seja totalmente plausível.

Considerando-se tais ações criativas, e o papel do professor em estar preparado para as devidas orientações (o docente deve estar atento para não desestimular o aluno em suas realizações, classificando o que é possível apenas no real como verdade a ser aceita sem questionamentos), serão apresentadas a seguir as concepções acerca da Inteligência Coletiva, que se faz presente quando vários conceitos são apresentados e discutidos, sem qualquer discriminação, formando uma esfera paralela à realidade, cuja manipulação depende, de forma relevante, do virtual enquanto capacidade humana.

\subsection{A Inteligência Coletiva como Noosfera de Virtualidade}

No sentido de se discutir o processo de assimilação dos conteúdos pela mente humana, foram apresentadas as seis premissas da Teoria da Gestalt, que tendem a mostrar como o indivíduo apreende, internaliza e exterioriza suas concepções em relação ao mundo ao seu redor. Tudo isso baseado no contexto simbólico - com regras específicas que tendem a formar a linguagem de um grupo - cuja manipulação depende da virtualidade, que permite a manipulação sem regras, contudo, com criatividade, ludicidade e subjetividade, das informações assimiladas. Assim sendo, cabe analisar como tais informações são armazenadas pela sociedade, a fim de que possam ser consultadas ou mesmo modificadas, para gerar novos conhecimentos e, desse modo, é gerada a Inteligência Coletiva.

A inteligência consiste na reunião e tratamento de informações para apoiar um processo de tomada de decisões (MASSAD, 2004). Analisando-se a presença do virtual em elementos da criação humana que envolve, exclusivamente, a capacidade mental, logo se pode concluir que a virtualidade é premissa para a existência da inteligência humana. Esta, por sua vez, como algo intangível, também se apresenta como virtual, isto é, presente nas realizações humanas enquanto potência, que gera atos concretos por meio da ação física dos homens. Tal afirmação possui grande importância, diante dos dados coletados que se referem à formação do indivíduo, de acordo com as constatações pertinentes ao estudo de caso. 
De acordo com a Teoria dos Jogos, as informações são trocadas entre o homem e seu meio ambiente por meio do espírito lúdico, envolvendo cooperação e competição.

A cooperação e, mais particularmente, a troca de idéias, a cooperação intelectual, é algo importante para o desenvolvimento cultural e social. A Internet é uma das ferramentas para esse desenvolvimento e é por isso que ela tem, em todo o mundo, um tal sucesso (LÉVY; MASSAD, 2004).

Portanto, têm-se para as duas modalidades de jogo denominações de Inteligência condizentes: as Inteligências Competitiva e Cooperativa, ambas formando, em conjunto, a chamada Inteligência Coletiva. Segundo Lévy, a Inteligência Coletiva compreende algo além de uma reunião do aprendizado de cada indivíduo, ela utiliza-se ainda de um jogo para se desenvolver a partir de tais aprendizagens:

\begin{abstract}
A Inteligência Coletiva não é um tema puramente cognitivo. Só pode existir desenvolvimento da Inteligência Coletiva se houver uma cooperação competitiva ou competição cooperativa. Trata-se de um jogo cooperativo, já que se acumulam conhecimentos, há um progresso do saber etc. Mas isso só é um processo cooperativo e plenamente cooperativo porque também é competitivo. Se não houvesse a liberdade de propor teorias opostas àquelas que são admitidas, evidentemente o progresso nos conhecimentos seria muito menor (LÉVY; MASSAD, 2004).
\end{abstract}

A formação da Inteligência Coletiva envolve outros elementos lúdicos, pois para jogar com a competição - que envolve o progresso das informações a partir da discordância de ideias já admitidas - e com a cooperação - sem que esta seja realizada de maneira forçada -, esta modalidade de Inteligência utiliza-se da liberdade (aspecto competição) e do vínculo social, da amizade (aspecto cooperação). Cabe ao docente, principalmente se for considerado o professor da instituição de estudo de caso, enquanto sujeito desta pesquisa, refletir a respeito de estimular em seus alunos também a ideia da cooperação. Afinal, se a Inteligência Coletiva depende da reunião de ideias e opiniões geradas a partir da virtualidade de cada pessoa na sociedade, não é conveniente que neste processo se pense em competição.

A face transcendental da Inteligência Coletiva está relacionada a uma teoria de Theillard de Chardin, que considera a evolução humana a partir de aspectos culturais e espirituais. Duas energias fazem parte do mundo físico, a radial (de essência física) e a tangencial (de essência divina, vinda de dentro do ser humano), sendo na última, encontrados três níveis: pré-vida, em relação aos seres inanimados; vida, para os seres vivos e consciência, pertencente ao plano humano (LEMOS, 2005). 
A consciência corresponde ao aparecimento do ser humano, formando desde então, através do pensamento reflexivo, várias camadas sobrepostas em uma espécie de rede invisível, a qual Chardin chama Noosfera. Sua faceta eletrônica viria com a constante interação humana com o virtual, desenvolvendo-se na pós-modernidade, a partir da cibercultura. A Inteligência Coletiva interage de forma inovadora com ciberespaço e seu conteúdo, colocando-o junto desta camada invisível de consciência, tornando a realidade virtual algo presente não só nos momentos de conexão com a "rede das redes", mas de presença constante e expansão planetária enquanto consciência coletiva (LEMOS, 2005).

A expansão do ciberespaço é colocada por Lévy como a descoberta de um quarto território humano. Se a terra era espaço do mito e do rito (ligando o homem ao cosmos), o território era o espaço do trabalho (início da atividade agrícola e dos primeiros Estados) e o mercado do trabalho e da velocidade (com as descobertas marítimas até a globalização dos mercados), o ciberespaço torna-se um espaço do saber, interligando-se às outras etapas da evolução como camadas comunicantes (LÉVY; MASSAD, 2004).

O espaço do saber é caracterizado não só pela expansão das mídias modernas de comunicação e pela modernização dos transportes, como também por uma economia caracterizada pela expansão das trocas e pela abolição de limites geográficos. Tal espaço geraria uma nova espécie de Inteligência Coletiva, “distribuída em todas as direções, valorizada sem cessar, coordenada em tempo real, e que chega a uma valorização e mobilização efetiva de competências". Assim se apresenta o jogo da Inteligência Coletiva diante da cibercultura (LÉVY; MASSAD, 2004).

A partir destes conteúdos, cabe analisar a importância da Inteligência Coletiva como forma de agrupar aquilo que vem a ser produzido pela virtualidade de cada ser humano. A Inteligência Coletiva apresenta-se, portanto, como união das competências humanas e tecnológicas, no que diz respeito ao uso da virtualidade para geração de ideias que contribuam não apenas com a assimilação, como também com a produção de novos conhecimentos, contribuindo-se deste modo com o desenvolvimento do virtual, a partir da ação conjunta de suas duas vertentes na formação dos educandos de maneira inovadora, conforme concepções abordadas pela instituição de estudo de caso e apresentadas a seus profissionais docentes. 


\title{
2. APLICAÇÃO PEDAGÓgICA DA VIRTUALIDADE NAS NOVAS TECNOLOGIAS COMO INOVAÇÃO EDUCACIONAL
}

\author{
"A realidade virtual corrompe, a realidade absoluta
}

corrompe absolutamente”.

(Roy Ascott, 1999)

\subsection{Do Cognitivo à Gestão do Conhecimento}

Até este ponto, a dissertação apresentou o modo como a virtualidade se faz presente enquanto capacidade mental humana, aliada à imaginação, à criatividade, ao simbólico e à linguagem. Também foi considerado o processo que envolve a assimilação, análise e devolutiva das informações, e o papel do virtual ao longo de tais realizações, contribuindo assim para a subjetividade do indivíduo, bem como para a compreensão que este vem a ter de seu contexto histórico e sociocultural.

Direcionando-se esta pesquisa para a contemporaneidade, faz-se mister analisar o virtual como elemento presente nas tecnologias de informação e comunicação - chamadas também de TICs, novas tecnologias, tecnologias de silício ou, simplesmente, tecnologias digitais (LÉVY, 1993; 1996) -, inclusive se for considerada sua manifestação nestes recursos como uma extensão da virtualidade que é base da imaginação humana (MCLUHAN, 1996). Assim sendo, seguem a essas considerações anteriores a discussão sobre o virtual nas novas tecnologias, bem como o uso das mesmas no aprendizado, com foco para as realizações da instituição analisada como estudo de caso desta pesquisa.

Diante do desenvolvimento de novos recursos de aprendizagem, a partir da evolução das novas tecnologias de comunicação e do desenvolvimento da cibercultura, surgem questões referentes a modos mais eficazes de educar, tendo como base a busca pela criticidade e formação do cidadão. Na questão da apreensão e desenvolvimento do saber, do senso comum às discussões acadêmicas, as mudanças aceleradas sentidas atualmente, em todas as áreas do conhecimento e da produção, são decorrentes de uma revolução tecnológica.

Adianta-se que tal afirmação se fez clara na coleta de dados, diante da ênfase, ou mesmo entusiasmo, apresentados pelos professores para com as novas tecnologias e com a virtualidade 
presente em seus recursos. Por isso seu destaque enquanto criação do virtual em sua primeira instância, a humana, em meio à intervenção direta do profissional docente na instituição de estudo de caso, por meio de suas realizações pedagógicas.

Segundo Schaff (1993), a primeira revolução pode ser situada entre o final do século XVIII e início do século XIX, quando se substituiu a força física do homem pela energia das máquinas. Hoje se assiste à segunda revolução, caracterizada pela ampliação das capacidades intelectuais do homem pela tecnologia. Esta revolução realiza transformações econômicas, sociais, políticas e culturais numa denominada sociedade informática:

(...) a sociedade informática escreverá uma nova página na história da humanidade, pois dará um grande passo no sentido da materialização do velho ideal dos grandes humanistas, a saber, o do homem universal, e universal em dois sentidos: no de sua formação global, que lhe permitirá fugir do estreito caminho da especialização unilateral, que é hoje a norma, e no de se libertar do enclausuramento numa cultura nacional, para converter-se em cidadão do mundo no melhor sentido do termo (SCHAFF, 1993, p. 71).

Lévy (1993) afirma que o universal não é o planetário, ou seja, não totaliza mais pelo sentido: ele conecta pelo contato, pela interação geral. "As fronteiras são as ruínas, ainda de pé, de um mundo em revolução. (...) O verdadeiro destino do homem é ser um planetário, participando ativamente da inteligência coletiva de sua espécie” (p. 33). Nesta sociedade, a educação permanente será um imperativo tal como o é a escola obrigatória, surgindo assim um novo tipo de homem: o homo studiosus:

(...) este homo studiosus seria a realização de um dos mais velhos sonhos humanistas, o homo universalis. O homem universal, ou aquele que está munido de uma instrução completa e em condições de mudar de profissão e ,portanto, também de posição no interior da organização social do trabalho (...) (LÉVY, 1993, p. 33-34).

Ambos os autores, respeitadas as diferenças, caracterizam o homem como ser social, fruto de uma comunidade que provoca efeitos no pensamento e no agir deste pela linguagem fruto de sua relação lúdica para com o meio ambiente -, pelo sistema de valores, pelas relações sociais. Ambos veem a tecnologia contribuindo para o aumento e a modificação das capacidades cognitivas do homem. A partir destas afirmações, torna-se claro o porquê de se analisar, em relação aos professores da instituição de caso, a necessidade de que estes profissionais desenvolvam os elementos referentes à virtualidade humana, como forma, inclusive, de garantir realizações realmente inovadoras, voltadas ao virtual apresentado por meio das novas 
tecnologias.

Há de se considerar, mais uma vez, a complexidade lúdica da apreensão humana de conhecimento, graças às propriedades exclusivas do cérebro do homem. Lévy (1993) reporta-se à velocidade de surgimento e renovação de saberes e à mudança da relação atual com o saber, pois a tecnologia favoreceria e favorece novas formas de acesso à informação e novos estilos de raciocínio e de conhecimento:

(...) o ciberespaço suporta tecnologias intelectuais que amplificam, exteriorizam e modificam numerosas funções cognitivas humanas: memória (banco de dados, hiperdocumentos, arquivos digitais de todos os tipos), imaginação (simulações), percepção (sensores digitais, telepresença, realidades virtuais), raciocínios (inteligência artificial, modelização de fenômenos complexos) (p.157).

A partir da afirmação de Lévy (1993) destaca-se a origem dos recursos tecnológicos a partir das capacidades humanas. Ocorre o mesmo com a virtualidade, que pode ser desenvolvida com a utilização das tecnologias digitais, sem que sejam ignoradas ou menosprezadas as criações advindas da imaginação e da criatividade. É este o ponto de vista que o docente deve possuir - e foi explanado durante a intervenção do pesquisador, de acordo com o respectivo relato - para o devido desenvolvimento do virtual no educando.

O impacto das novas tecnologias na informática e comunicação afeta todo o universo social, criando novas dinâmicas em que o conhecimento vai se tornando gradualmente central. As mudanças técnicas desta revolução são simples: as formas de comunicação não são novas, tampouco misteriosas. Em relação às decisões e apreensões no meio virtual, como bem afirma Lévy (1993),

a cultura digital é a cultura dos filtros, da seleção, das sugestões e dos comentários. Os mecanismos de busca de última geração, os agentes inteligentes e as comunidades virtuais seriam estratégias que visam poupar os usuários do martírio da opção entre uma miríade de possibilidades. No confronto com o excesso, nasce a percepção de que as escolhas se orientam de modo muito mais complexo do que uma decisão simples e objetiva entre uma coisa ou outra (p. 34).

Considerando-se os elementos até aqui discutidos, cabe apontar o destaque que as novas tecnologias possuem, de um modo geral, no inconsciente dos professores, pois originalmente eles apresentam, conforme demonstram os dados da coleta de dados realizada no estudo de caso, a ideia dos recursos digitais como fontes ilimitadas de aprendizado ou mesmo criatividade. Um 
dos elementos que estimula tal noção é a flexibilidade que o virtual apresenta também no contexto das tecnologias digitais.

Na verdade, o princípio da virtualidade nos âmbitos humano e cibernético é a mesma, uma vez que os recursos tecnológicos possibilitam uma agilidade e, de certo modo, uma simplicidade no processo de armazenamento e transmissão de conteúdos, bem como permitem a visualização em grupo - por meio de imagens ou mesmo hologramas (LÉVY, 1996), produzidos em softwares específicos e exibidos em monitores convencionais ou de LCD/plasma - do que antes era contemplado apenas individualmente, na mente daquele (a) que houvesse imaginado um objeto, ser ou fenômeno, antes que o mesmo se tornasse real/atual, ou que não houvesse sequer existido.

Essa associação de conceitos relacionados ao virtual, entre a capacidade criativa do ser humano e a possibilidade de compartilhar uma visualização não-real/atual de sua criação, por meio dos recursos computacionais, vem a ser primordial para a compreensão de quais elementos devem ser estimulados no processo de ensino e aprendizagem, principalmente, voltado à virtualidade do educando.

O acervo de conhecimentos da humanidade passou para uma base que é infinitamente pequena, tornando-se um verdadeiro fluido, de maleabilidade ilimitada. O sistema digital permitiu a rápida convergência de todos os instrumentos que geram, transmitem e recebem informações: “(...) este conjunto de atividades agigantou-se de maneira fenomenal, garantindo um papel absoluto nas atividades em geral” (DOWBOR, 2001, p. 22).

A Internet é simplesmente o sistema de suporte organizado à comunicação planetária e, por si somente, é o meio em que são produzidas e armazenadas as informações pertinentes à Inteligência Coletiva. Parte do indivíduo, com base nas orientações educacionais, tornar esse processo do saber em rede válido para a autoconstrução do conhecimento e de suas atitudes enquanto cidadão. "Quando o conhecimento torna-se um elemento-chave de transformação social, a própria importância da educação muda qualitativamente. Deixa de ser um complemento e passa a adquirir novo posicionamento no processo" (DOWBOR, 2001, p. 24). Com essa concepção de Dowbor, torna-se clara a importância da Inteligência Coletiva em relação à transformação real da sociedade a partir do conhecimento, destacando-se neste ponto a importância das ideias criativas, e o papel da virtualidade no desenvolvimento dos saberes discentes.

As transformações estão caminhando a uma sinergia da comunicação, informação e formação, criando uma realidade nova. Exigindo, inclusive, a reflexão para que se evite o reforço 
das desigualdades, repensando de forma mais dinâmica e com novos enfoques a questão do universo de conhecimentos gerados, no reconhecimento de que, mesmo em uma área especializada, a apreensão de informações torna-se praticamente impossível.

A partir de algumas constatações desta pesquisa, a serem apresentadas posteriormente, no relato do estudo de caso, verificou-se que se faz necessário trabalhar com as tecnologias na educação de maneira séria, sem ilusões, pois tanto podem servir para a elitização e o aprofundamento das contradições sociais como para a democratização do conhecimento, e esta deve ser uma das preocupações docentes, voltadas à formação do indivíduo e à utilização de saberes que estejam voltados à inovação.

Dowbor (2001) confirma tal necessidade, ao afirmar que “é vital disponibilizar amplas redes de comunicação para transformar a educação num processo interativo de enriquecimento mútuo, de escolas de qualquer parte do mundo" (p. 72). Explica-se, portanto, as possibilidades de se trabalhar com o ensino à distância, que não se resume a uma prática autodidata ou que apenas serve para otimizar o tempo do aluno.

A importância deste módulo educacional está na conexão de estudantes, pois hoje não se pode mais buscar soluções isoladas na Educação, na Comunicação, mas em diversos espaços culturais. O conjunto das atividades humanas tornou-se intensivo em conhecimento - fato reconhecido, inclusive, em meio às opiniões colhidas por meio do questionário utilizado nesta pesquisa - e quanto mais competências forem utilizadas, tanto na educação à distância como na presencial, mais possibilidades terá o professor de desenvolver habilidades específicas em seus alunos, incluindo a virtualidade.

As considerações relacionadas à educação à distância oferecem premissas para que se analise o uso complementar das novas tecnologias, o que é realidade na instituição analisada no estudo de caso, pois mesmo que um ambiente virtual de aprendizagem não seja foco nas realizações do Ensino Fundamental da Escola Mário Covas, o modo como o docente lida com as novas tecnologias é praticamente o mesmo. Isto é, em um contexto educacional, a tendência é que ou as tecnologias digitais sejam desconsideradas, em meio aos conteúdos curriculares ou, de maneira totalmente inversa, sejam supervalorizadas enquanto fonte de informações, sendo então incluídas em diversas atividades pedagógicas.

O virtual ganha, portanto, destaque enquanto elemento mental, que possibilita ao ser humano utilizar-se da imaginação para elencar inúmeras possibilidades para uma única realização, as quais podem ainda ser aplicadas a partir de outras capacidades mentais e físicas, tais como a concentração e os movimentos, por exemplo. 
Tais concepções foram consideradas na análise direcionada à instituição de estudo de caso, tendo sido complementada pela ideia de que "a virtualização pode ser definida como o movimento inverso da atualização" (LÉVY, 1996, p. 17). Ao projetar sua imagem virtual, portanto, o indivíduo tenta sempre colocar não sua imagem atual, tampouco uma de suas personas, mas cria uma nova imagem, idealizada a partir do que ele pode vir a ser (JUNG, 1998).

A ideia de uma projeção de si mesmo no mundo virtual das novas tecnologias possibilita ao aluno trabalhar com o planejamento, feito de forma anterior às realizações escolares, bem como as criações que venha desenvolver paralelamente. Tal liberdade para promover a composição por meio do imaginário, com o auxílio da visualização permitida pelo ambiente virtual dos recursos digitais, com certeza, vem a ser uma prática proveitosa, principalmente no caso da Escola Municipal Mário Covas, que tem pretensões de seguir as ideologias da Escola da Ponte.

“A virtualização não é uma desrealização, mas uma mutação de identidade, um deslocamento do centro de gravidade ontológico do objeto considerado" (LÉVY, 1996, p. 18). Ou seja, assim como a semente é virtualmente uma árvore e um pensamento é atualizado no discurso, o homem refaz-se a cada imagem projetada a partir da mudança para o virtual.

A partir desta afirmação de Lévy é possível compreender a importância de reconhecer a capacidade humana de projetar-se mentalmente em seu próprio futuro. A proposição docente de que o aluno mentalize suas ideias antes de colocá-las em prática - apresentada no relato elaborado a partir da instituição de estudo de caso - é a maneira mais simples de fazer com que ele reconheça a sua própria virtualidade.

O contato mais comum e constante do homem contemporâneo com a realidade virtual sem dúvida é a rede mundial de redes de computadores, mais conhecida por Internet. Sua origem, segundo Nicola (2004), foi um projeto de 1969 do Departamento de Defesa (DOD) dos Estados Unidos: a Arpanet, uma rede inicial de computadores que utilizava o mesmo protocolo de interconexão (TCP/IP) que fez surgir a Internet. O sistema de redes tornou-se tão complexo que é possível utilizar o termo ciberespaço, ou ainda cibersociedade (2004, p. 25).

O termo ciberespaço, criado pelo ciberpunk William Gibson em seu livro Neuromancer, pode ser considerado "como um conjunto de computadores interligados, um computador hipertextual, disperso, vivo, fervilhante, inacabado" (NICOLA, 2004, p. 26). Tal sentença só confirma a inconstância inerente do virtual: ele nunca será algo pronto, acabado. Portanto, tudo o que for por ele composto, terá também, uma estrutura de constantes modificações, aliando-se à 
afirmação de Cardoso, para quem "o ciberespaço é uma espécie de corredor de passagem, um hiperterminal planetário onde toda a informação circula, um 'não-lugar'” (In NICOLA, 2004, p. 26).

A partir do momento em que se admite o ciberespaço como componente principal no jogo da Inteligência Coletiva, devem ser avaliadas as significações sociais, em relação a este novo meio de propagação de informações, bem como o fenômeno de descentralização das mesmas - proposições apresentadas em meio à intervenção do pesquisador voltada ao corpo docente de seu estudo de caso. Discussões e propostas podem ser colocadas tanto para a melhoria da realidade virtual como também para utilizar exemplos bem variados (e geograficamente afastados) para se resolver um problema no mundo real.

Outra questão que foi considerada na análise do estudo de caso foi a intervenção do aluno durante as aulas, para que as ideias pudessem, desse modo, ser estimuladas pelo professor, de forma dinâmica e orientada, seguindo mais uma vez os preceitos citados por José Pacheco (2000). Afinal, propor discussões é uma atividade da cibersociedade, exercida com todo direito pelo cibercidadão. Por esse e outros motivos, a cibercultura é considerada uma expansão da realidade, colaborando com a quarta camada de inteligência com uma realidade ampliada,

(...) talvez seja esta a maior das vocações da realidade virtual: a simulação de movimentos, de ações, de sensações. (...) Num ambiente simulado, podemos fazer qualquer coisa sem correr os riscos que haveria se tivéssemos interagindo no real. (...) A animação de imagens em tempo real torna-se uma atividade lúdica e estética. A evolução, a transformação e a metamorfose de imagens transformam em metáforas da vida as suas representações. $\mathrm{O}$ crescimento, a expansão, a mudança e a metamorfose simulam um tipo de pensamento icônico. O prazer encontra-se na comparação entre aquilo que se imaginou e o que vemos nascer (PLAZA In GALISI, 2003, p. 38).

Do contato virtual dos chats, como em um baile de máscaras contemporâneo, aos jogos em três dimensões, em um tele-transporte para dentro dos cenários e da evolução de enredos e personagens, pode-se extrair a idéia de que o virtual e a realidade parecem reproduzir a sucessão de imagens refletidas por dois espelhos, um à frente do outro, com um corpo ou ambiente entre eles, num incessante processo de projeções, de criações contínuas de simulacros que não nos permitem mais saber em que estágio da cadeia reprodutiva cada imagem se encontra.

Desenvolver a virtualidade, portanto, vai além de reconhecer a capacidade de projetar-se no futuro por meio de diversas possibilidades mentais de ação e criação, pois é imperativo entender que existe uma linha tênue que distingue o que é fruto exclusivo da imaginação em 
relação ao que pode ser realizado de algum modo, mesmo que inédito - questões também apresentadas na intervenção do pesquisador para com os professores da escola de estudo de caso.

\subsection{A Função do Lúdico na Educação e o Ensino à Distância}

Conforme discutido no item anterior, a virtualidade promove não apenas a exploração ilimitada da criatividade e imaginação humanas como também possibilita o armazenamento e transmissão destes conteúdos gerados, por meio da visualização e do planejamento em relação ao que foi imaginado, antes mesmo que se torne real/atual. No contexto nacional, o uso das novas tecnologias, aliado ao processo de ensino e aprendizagem, tem como ícone o ensino (ou educação) à distância, e em relação a esta, cabem algumas considerações, principalmente para que seja determinado se os recursos tecnológicos são bem empregados, sem que se tornem o foco principal deste módulo de aprendizagem.

Não há pretensões de se desenvolver neste texto a ideia da educação à distância (EAD) como um modo totalmente eficaz de ensinar, ou ainda como a solução para conduzir todos os homens à sua formação educacional plena. Apenas se deseja considerar o modo pelo qual a EAD, por se utilizar de um ambiente com características virtuais - que permite ao usuário a visualização das inúmeras possibilidades que deseja aplicar a uma só realização, tal como o próprio computador -, pode proporcionar o aprendizado de maneira ainda mais produtiva, desde que aliado à virtualidade do educando devidamente desenvolvida.

Fenômenos como a planetarização de Lévy, a universalização de Schaff ou a globalização descrevem um fenômeno que se relaciona com a transformação do espaço e do tempo. Um fenômeno também relacionado com o surgimento de novos meios de comunicação e de transporte em escala planetária. A diversão confunde-se com a aprendizagem, e novas formas de aprender parecem caber dentro dessa idéia de educação-entretenimento.

A entrada do computador na sala de aula, principalmente no final da última década, trouxe questões que dizem respeito não só ao uso do computador como, principalmente, sobre o uso de outras tecnologias. Tomada em seu sentido mais geral, pode-se dizer que tecnologia é o conjunto ordenado de todos os recursos empregados na produção e comercialização de bens e serviços; no caso da educação, recursos que podem contribuir para sua eficácia, ou seja, que podem possibilitar maior aprendizagem dos alunos. Tentar-se-á comprovar tal afirmação ao 
longo da pesquisa, de forma devidamente apresentada na discussão até este instante, e também posteriormente, nesta dissertação.

Segundo Lévy (1993), a tecnologia é produzida dentro de uma cultura e a qual acaba condicionada por aquela, no sentido de que, a partir da existência de uma dada técnica, a sociedade que a possui acaba por não mais viver sem ela, pelas possibilidades que se abrem com essa tecnologia. Se hoje existe na sociedade a presença de computadores - tecnologia presente em quase todos os âmbitos da nossa vida - essa condicionaria a escola, que faz parte da sociedade.

Uma tecnologia não é boa nem má, mas depende do uso que se faz dela, do contexto em que se insere. A questão é definir qual é utilizável na educação. Mais até, é essencial a convicção de que seu uso deva ser acompanhado da reflexão sobre a mesma. Determinar a importância desta ou daquela tecnologia, em termos de ajudar o aluno na construção do conhecimento, tem sido uma preocupação recorrente de muitos educadores. Na atualidade, a presença da informática na educação é importante, é inevitável, dado que o computador tornou-se objeto sociocultural integrante do cotidiano das pessoas:

O saber-fluxo, o trabalho-transação de conhecimento, as novas tecnologias da inteligência individual e coletiva mudam profundamente os dados do problema da educação e da formação. O que é preciso aprender não pode mais ser planejado nem precisamente definido com antecedência. Os percursos e perfis de competências são todos singulares e podem cada vez menos ser canalizados em programas ou cursos válidos para todos. Devemos construir novos modelos do espaço do conhecimento. No lugar de uma representação em escalas lineares e paralelas, em pirâmides estruturadas em 'níveis', organizadas pela noção de pré-requisitos e convergindo para saberes 'superiores', a partir de agora devemos preferir a imagem de espaços de conhecimentos emergentes, abertos, contínuos, em fluxo, não lineares, se reorganizando de acordo com os objetivos ou os contextos, nos quais cada um ocupa uma posição singular e evolutiva (LÉVY, 1993, p. 158).

A capacidade multimídia que a Internet possui permite uma interação, de certa forma divertida, em relação ao saber, incluindo a questão do "faz-de-conta" propiciada, por exemplo, pelos jogos eletrônicos online e/ou pedagógicos. A diversão é essencial não só para que a apreensão virtual de conhecimentos mantenha-se fiel ao seu conceito original, mas para que sua função nas atividades da cultura humana possa surtir os efeitos desejados, incluindo o de ferramenta de aprendizado. Essa união da cultura com a transmissão de informações é, inclusive, um dos pontos centrais da discussão deste capítulo e foi devidamente especificada na discussão a respeito dos jogos eletrônicos. 
Através da tecnologia, portanto, não é somente estabelecida uma relação de instrução por meio da percepção audiovisual. O caráter plástico - tal como o cérebro humano - e lúdico que o ambiente virtual possui, permite que o educando projete-se, de certo modo, em uma exploração simultânea de duas realidades, apreendendo informações, de modo crítico, com as duas experiências. Tal afirmação também foi alvo de discussões na intervenção do pesquisador em relação ao estudo de caso da presente pesquisa, e pode ser comprovada por Lévy (1996):

\begin{abstract}
A palavra 'virtual' pode ser entendida em ao menos três sentidos: o primeiro, técnico, ligado à informática, um segundo corrente e um terceiro filosófico. (...) no uso corrente, a palavra virtual é muitas vezes empregada para significar a irrealidade - enquanto a "realidade" pressupõe uma efetivação material, uma presença tangível. Em geral, acredita-se que uma coisa deva ser real ou virtual, que ela não pode, portanto, possuir as duas qualidades ao mesmo tempo. Contudo, a rigor, em filosofia o virtual não se opõe ao real mas sim ao atual: virtualidade e atualidade são apenas dois modos diferentes da realidade. Se a produção da árvore está na essência do grão, então a virtualidade da árvore é bastante real (sem que seja, ainda, atual) (p. 29).
\end{abstract}

O virtual, portanto, existe sem estar presente. Desse modo, não se refere ao ambiente virtual como oposto ao presencial no sentido de existência real, mas como um ambiente diferente, que pressupõe relações reais entre as pessoas e, assim, entre professores e alunos. Dificuldades e facilidades que um professor encontra na sala de aula presencial também poderão ser encontradas por na EAD; as qualidades necessárias a um professor presencial, provavelmente, serão necessárias à distância e assim por diante.

A diferença está no ambiente e na forma de ensinar, e não na função da educação ou no processo de ensino e aprendizagem, e esse é o ponto central quando se considera o processo de ensino e aprendizagem neste módulo educacional - questão também apresentada na análise da instituição de estudo de caso.

A Internet vem se consubstanciando como um ambiente de comunicação, de relacionamento. A ideia principal é de que a Internet não seja uma rede de redes de computadores, mas de pessoas interconectadas. Pessoas dos mais diferentes lugares, das mais diversas profissões, que se comunicam, não por estarem próximas, mas por partilharem interesses, ideias, tornando, de certo modo, real a projeção, antes, exclusiva da mente, pela virtualidade humana. Pessoas que buscam informação, mas que também têm conhecimentos e os socializam, colaboram entre si, compartilham propostas e recursos, aprendem juntas. A este respeito, Lévy (1996) cria a idéia da inteligência coletiva que se produz no ciberespaço: 
O ciberespaço, dispositivo de comunicação interativo e comunitário, apresenta-se justamente como um dos instrumentos privilegiados da inteligência coletiva. (...) Os pesquisadores e estudantes do mundo inteiro trocam idéias, artigos, imagens, experiências ou observações (...). O especialista de uma tecnologia ajuda um novato enquanto um outro especialista o inicia, por sua vez, em um campo no qual ele tem menos conhecimentos (...) (p. 31).

O impacto que isso pode trazer à educação diz respeito a novas formas de ensinar e de aprender, pois tira da escola o controle sobre a aprendizagem das pessoas (FREIRE, 2002). O ensino, que antes era domínio exclusivo da escola, ocorre fora dela, já que na interação via rede, muitos podem ensinar e também podem aprender com quem interagem. Entretanto, ainda que a rede de computadores possibilite o desenvolvimento da inteligência coletiva e provoque mudanças nas formas de construção de conhecimento, há de alertar-se para o outro lado desse fenômeno: a exclusão daqueles que não fazem parte do ciberespaço:

\begin{abstract}
Devido a seu aspecto participativo, socializante, descompartimentalizante, emancipador, a inteligência coletiva proposta pela cibercultura constitui um dos melhores remédios para o ritmo desestabilizante, por vezes excludente, da mutação técnica. Mas, neste mesmo movimento, a inteligência coletiva trabalha ativamente para a aceleração dessa mutação. Em grego arcaico, a palavra "pharmakon" (que originou "pharmacie", em francês) significa ao mesmo tempo veneno e remédio. Novo pharmakon, a inteligência coletiva que favorece a cibercultura é ao mesmo tempo um veneno para aqueles que dela não participam (...) e um remédio para aqueles que mergulham em seus turbilhões e conseguem controlar a própria deriva no meio de suas correntes (LÉVY, 1996, p. 33).
\end{abstract}

Não obstante, não basta a "alfabetização digital": é necessário criar condições para desenvolver nos alunos uma autonomia intelectual, que lhes permita selecionar e escolher o que o mundo virtual pode lhes oferecer de melhor. A proliferação de cursos à distância dos mais variados assuntos e formatos, ainda que a qualidade de muitos possa ser questionável, e a busca por melhoria de desempenho e formação para competir no mercado de trabalho, chama a atenção dos educadores para a necessidade de repensar o papel da escola e o papel do professor e sua ressignificação como profissional.

O interesse de um número cada vez maior de pessoas por participar de um curso a distância revela, entre outros aspectos, que a busca por construir novos conhecimentos e desenvolver novas habilidades está sendo compatibilizada com a administração do próprio tempo. A tecnologia hoje disponível tem de servir para a otimização desse tempo: com a utilização da informática na educação, com a disseminação do uso da Internet, transforma-se a idéia inicial da educação à distância, como reprodução tecnológica da aula tradicional, em espaço virtual de construção de conhecimento. 
O Ambiente Virtual de Aprendizagem (AVA) é uma ferramenta pedagógica que alia a educação à distância com a praticidade da conexão à Internet, possibilitando ao aluno do módulo EAD consultar o material paralelo ao Guia de Estudos (textos, links e/ou reportagens enviados pelos professores), realizar suas atividades, contatar colegas, tutor (es) e professor (es) e ainda participar de um fórum de debates. Sua importância como ferramenta pedagógica é a maior dentre os recursos utilizados, já que o aluno EAD desenvolve a maior parte de seu curso neste ambiente, seja consultando os materiais de leitura ou realizando as atividades propostas para a semana. Portanto, praticidade e eficácia devem ser prioridades durante sua utilização.

A educação à distância permite que o ensino superior possa ser oferecido a diversas localidades do país, principalmente em regiões onde há carência de instituições adequadas para o propósito. Com este sistema, o aluno tem a flexibilidade de horário de estudo, de forma que seja adequado à sua disponibilidade e localidade, já que é possível acessar o ambiente virtual de estudo de qualquer computador com conexão à Internet.

Esta modalidade de aprendizado estimula a autonomia de cada aluno, fazendo-o participar das aulas em caráter pró-ativo, onde ele busca o conhecimento e obtém completo suporte pedagógico da Universidade, por um investimento acessível, desde que sejam estimuladas capacidades que dizem respeito à virtualidade enquanto capacidade humana - objeto de discussão de todo o primeiro capítulo, analisado nas realizações da instituição de estudo de caso da presente pesquisa. Destaca-se ainda o fato de que a EAD é o sistema de aprendizagem que mais cresce no país.

Em 2005, havia 82 cursos de graduação à distância credenciados no Brasil e mais de 109 mil alunos matriculados, segundo o Anuário Brasileiro Estatístico de Educação Aberta e à Distância de 2006 (UMESP, 2007). O mercado de trabalho começa a reconhecer o valor que a EAD proporciona aos novos profissionais, formados por um sistema que inibe a atitude passiva e capacita trabalhadores com perfis de pró-atividade. Observam-se empresas que tanto acreditam como também usufruem da EAD como método de treinamento para a capacitação de seus colaboradores.

Conforme determinado pelo Decreto 5.622 de 19/12/2005, os cursos superiores à distância têm a mesma validade de um curso presencial (ASSOCIAÇÃO, 2009). Por ser apenas outra modalidade de oferecimento não há diferenças entre os diplomas emitidos para os cursos EAD. Além disso, o Decreto 5.622 regulamentou a equivalência irrestrita entre diplomas presenciais e a distância, o que conferem a eles validade em todo o território nacional. 
O que antes, portanto, poderia ser um aprendizado solitário, individual, pode transformarse em algo que pertença à Inteligência Coletiva, característica de uma comunidade virtual de aprendizagem colaborativa, criando uma nova concepção de apreensão de conhecimento. Uma escola na qual alunos e professores podem cooperar uns com os outros, para que todos avancem. Caem as fronteiras das salas de aulas e os limites de determinação de horário. Busca-se o desenvolvimento da autonomia intelectual do aluno. Selecionam-se conteúdos que melhor atendam às necessidades de uma comunidade virtual que está em constante processo de aprendizagem.

Mudanças aceleradas transformam o mundo, tornando as verdades cada vez mais provisórias. Ideias estas que podem, inclusive, serem aplicadas do mesmo modo no ensino presencial, por meio de atividades que proponham aos alunos a quebra de antigos paradigmas escolares - conforme questões analisadas em relação ao corpo docente da escola de estudo de caso.

Retornando o foco em relação à educação à distância, podem ser consideradas outras propostas de mudanças. O aluno, a quem tradicionalmente cabia receber a informação e processá-la, fica no mundo virtual diante do desafio da auto-aprendizagem, da administração do tempo, da autodisciplina, da comunicação mediada pelo computador. Sua participação não se restringe mais a estar presente (fisicamente) numa sala de aula, mas exige, efetivamente, sua interferência, sua manifestação, sua comunicação. Se a escola falha ao lhe solicitar uma postura mais ativa, de discutir, analisar, problematizar, no mundo on-line ele é chamado a esse tipo de atuação, e vice-versa.

Quebra-se assim a crença de que, com as novas tecnologias, o professor teria sua extinção certa e inevitável, aplicando-se um pensamento de Paulo Freire sobre o valor eterno de ensinar: "Quanto mais penso sobre a prática educativa, reconhecendo a responsabilidade que ela exige de nós, tanto mais me convenço do dever nosso de lutar no sentido de que ela seja realmente respeitada" (2002, p. 107).

Segundo Freire (2002), o educando possui, enfim, a possibilidade de trabalhar à sua maneira os conhecimentos apreendidos, tanto quanto uma postura mais crítica e ativa diante de tão inovador aprendizado. Coloca-se, neste aspecto, a postura docente atual na importância de destacar atividades que estimulem a pesquisa discente, por meio de orientação adequada, já que este também é um modo pelo qual se estimula a virtualidade no ambiente escolar, conforme concepções relatadas até este ponto, bem como informações coletadas sobre a instituição neste estudo de caso. 
A partir das afirmações relacionadas ao modo pelo qual o educando apreende, processa e assimila as informações, será discutido a seguir o modo com que as novas tecnologias integram as atividades docentes, bem como a transmissão e discussão de conteúdos, de modo a desenvolver com os alunos possibilidades tão diversificadas quanto as que eles possam gerar, por meio da imaginação e criatividade. Esta relação dos recursos digitais com as propostas feitas pelo professor aos seus alunos também foram analisadas no estudo de caso, cabendo, portanto, apresentar quais elementos são os mais relevantes neste processo de ensino e aprendizagem, a partir dos dados coletados na Escola Municipal Mário Covas.

\subsection{O Professor e as Novas Tecnologias no Desenvolvimento do Saber}

Para que pudesse ser compreendido o profissional docente que se apresentava na referida escola de ensino municipal, recorreu-se a Lévy (1993), que afirma que em meio ao desenvolvimento da sociedade em rede, a escola enquanto instituição aprendente deve buscar compreender a importância do ser professor, pois o mesmo tem a possibilidade de assumir o papel de orientador de seus educandos, em relação aos dados apreendidos em meio às novas tecnologias, auxiliando o processamento de informações pelos alunos para o uso cotidiano.

Além disso, suas funções devem abranger características inovadoras, como suscitar a autonomia no educando, trabalhando sua criticidade por meio de conteúdos interdisciplinares, desenvolvidos concomitantemente. A autonomia e a visão crítica, segundo Freire (2002), detectadas como necessidades dos educandos, inclusive na coleta de dados da presente dissertação, podem ser colocadas como prioridade na atuação dos professores e no ambiente escolar, para que sejam valorizadas devidamente por discentes e docentes no ensino superior.

Ainda visando à compreensão do professor da Escola Municipal Mário Covas, analisa-se a possibilidade deste profissional de fomentar a autonomia e a visão crítica, segundo as concepções de Dowbor (2001). Para este autor, a atuação do professor, em meio à era da informação, conta com novos obstáculos, que reclamam a adesão de novos paradigmas educacionais. As novas maneiras de aprender e ensinar não seriam verdadeiramente possíveis, tampouco viáveis, sem a colaboração das novas tecnologias de informação e comunicação.

Também não se pode concluir que bastam as teorias mais avançadas da informação e da comunicação para estar tudo resolvido em relação à aquisição de conhecimento e visão crítica voltadas às informações apreendidas. Pelo contrário, os grandes desafios colocam-se, segundo 
Freire (2002), ao nível dos conteúdos e das dinâmicas de interação e colaboração entre os diferentes atores, sem condicionar ou diminuir a sua própria autonomia.

Para análise das atuações docentes, envolvendo a referida instituição de estudo de caso, considerou-se o acesso dos alunos aos conteúdos disseminados nas novas tecnologias, sem a devida análise, em relação aos conteúdos e a velocidade com que são apreendidos, pois não basta ter as, cada vez mais disponíveis e rápidas, "auto-estradas" da informação e da comunicação. Isso é, sem dúvida, um avanço excelente, mas não é menos importante tudo o que circula por essas "auto-estradas" cada vez mais freqüentadas, entupidas, congestionadas.

A preocupação em campo deu-se no sentido de que, se não for resolvido rapidamente o problema da qualidade dos conteúdos nas "auto-estradas", muitas tornar-se-ão simplesmente “intransitáveis" e "altamente poluídas” (NICOLA, 2004, p. 36). Tal questão destaca a atuação do professor enquanto orientador do educando, em meio das vias lotadas de conteúdos, visando a sanar o problema da ansiedade informacional por meio de aulas que desenvolvam a análise crítica destas informações, conforme foi discutido durante a explanação do pesquisador para com o corpo docente da instituição de estudo de caso.

Segundo Lemos (2004) seleção e qualidade dos conteúdos já são o grande desafio do presente e serão, com certeza, de um modo mais decisivo no futuro. Por isso, as capacidades e competências a serem desenvolvidas e adquiridas pelos alunos, sejam elas mais básicas ou específicas, não poderão passar ao lado desta realidade. A revolução do texto eletrônico leva à desmaterialização da obra e às suas diferentes materializações, que possuem identidades específicas. Essa também é uma característica da virtualidade: permitir que as produções humanas, inclusive relacionadas à linguagem, sejam reimaginadas e reestruturadas, de acordo com a criatividade do indivíduo, um dos elementos fundamentais, inclusive a ser considerado em relação aos dados coletados na instituição de estudo de caso.

Recorreu-se a Chartier para analisar o docente da Escola Municipal Mário Covas, e o modo como as diferentes opiniões e os diversos contextos dos alunos são por ele trabalhados; a concepção do autor reside em que "a obra não é jamais a mesma quando inscrita em formas distintas; ela carrega a cada vez, um outro significado" (2000, p. 71). Embora a tendência atual seja a de considerar que o estoque textual pode ser distribuído por diferentes fluxos, ele sugere uma inversão na maneira de pensar, partindo das variadas modalidades de difusão, para então abordar o tipo de estoque adequado para um mesmo texto. Da afirmação do mesmo autor, podese considerar alguns dados coletados que revelam a presença da virtualidade nas práticas do professor em relação às suas aulas, bem como os diversos significados que uma mesma aula ou 
simples explicação pode proporcionar a cada aluno - questão apresentada na intervenção realizada pelo pesquisador no estudo de caso desta pesquisa.

A partir das questões teóricas discutidas, com foco voltado à instituição de estudo de caso, até o presente momento nesta pesquisa, segundo a literatura estudada sobre a virtualidade e o processo de apreensão do conhecimento, pode-se considerar que não basta focar exclusivamente as novas capacidades e competências que devem ser adquiridas. É preciso que, ao nível das políticas, organização, gestão curricular e institucional, sejam criadas condições para que essas capacidades e competências se realizem. Certamente, tais premissas serão conhecidas em breve, e espera-se que o resultado não seja, mais uma vez, decepcionante e venha confirmar desatenção e inoperância crônicas na educação. Por conseguinte, segundo Lévy (1993), não basta no âmbito educacional falar de choques ou de planos tecnológicos para justificar mais gastos e gerar mais empregos - embora, em sociedades mais desenvolvidas, tenha-se verificado o efeito contrário.

Também foram adotadas as concepções de Miranda (1997), para que a atuação docente na instituição de estudo de caso pudesse ser verificada, inclusive em relação à necessidade de que as novas tecnologias de informação e comunicação sejam postas ao serviço de novos conteúdos, novos conhecimentos e novas aprendizagens, que ajudem não apenas a transformar ou transmutar os processos, mas que o sucesso de todos os seus atores melhorem-nos significativamente, quer do ponto quantitativo e/ou qualitativo.

Tais pensamentos, de acordo com Lévy (1996) deverão transmitir à sociedade uma nova concepção, servida por uma nova atitude por parte dos docentes e dos discentes, que só será possível com uma nova formação dos principais atores, com base num novo conhecimento (ou ciberconhecimento), numa nova aprendizagem (ou ciberaprendizagem), à luz de uma outra visão da realidade que não é possível esconder mais, face aos enormes avanços da ciência e tecnologia.

Segundo Dowbor (2001) - a partir de ideias complementares as de Lévy (1996) -, esta nova concepção de mundo não poderá, de forma alguma, estar ausente das novas modalidades de aprendizagem e ensino, deverá, pelo contrário, formatar a ação dos atuantes do processo. Conforme dados coletados e a discussão realizada durante a intervenção do pesquisador com o corpo docente do estudo de caso, mostra-se cada vez mais frequente a preocupação destes profissionais em relação à utilização de recursos cada vez mais inovadores, que contribuam de maneiras diferenciadas e diversificadas, voltadas ao processo de ensino e aprendizagem. Tais questões também foram consideradas no estudo de caso realizado, a partir do momento em que também se reconhece a importância de estímulo à criatividade e imaginação, já que sem estas 
capacidades humanas, o uso dos recursos tecnológicos em âmbito pedagógico perdem totalmente o sentido.

A nova realidade impõe novas modalidades de aprender e ensinar, obrigando a rever e alterar atitudes (FREIRE, 2002). Este parece um fato incontroverso, pois para isso os próprios sistemas de formação e a sua organização, gestão, realização e avaliação terão que realizar uma revolução nas concepções, atitudes, conteúdos, processos, modos de trabalho, espaços e tempos escolares. O foco então se volta para a importância de analisar o ensejo, por parte do corpo docente da instituição de estudo de caso, para que tal revolução seja efetivada, ainda mais na atual empreitada de aplicarem-se os ideais da Escola da Ponte.

As discussões apresentadas também foram baseadas em Dowbor (2001), na análise da posição do professor na referida instituição de estudo de caso, voltada ao seu plano de aulas, bem como o modo com que os conteúdos são por ele expostos. Em relação às concepções do autor, é possível ao profissional docente questionar se faz sentido hoje, por exemplo, a organização tradicional de sua atuação em aulas teóricas, teórico-práticas, práticas e/ou laboratoriais, com a rigidez dos métodos conhecidos. O que acontece, devido a uma cultura propagada desde a escola base, é que os alunos frequentam as aulas porque são obrigados, e cada vez pensam que as teorias servem para muito pouco.

Para que fosse analisada a maneira com a qual o professor da instituição deste estudo de caso organiza os conteúdos a serem ministrados bem como o ambiente a ser utilizado, recorre-se a Miranda (1997). A autora aponta que o trabalho, nos diferentes espaços disciplinares, terá que ser "organizado, gerido, realizado e avaliado de formas bem diferentes, quer nas aulas teóricas ou práticas" (MIRANDA, 1997, p. 34). Não basta que, no contexto curricular das escolas em âmbito nacional, algumas aulas sejam obrigatórias e outras não, mas que todas sejam lugares de trabalho e aprendizagem ativa, produtiva, colaborativa, responsável e autônoma (FREIRE, 2002)

Contudo, também é necessário que os alunos já venham habituados a um ethos autônomo e responsável. Segundo Miranda (1997), há experiências inovadoras e criativas que já são desenvolvidas, em que a dificuldade de realização é grande, pois ainda são pequenas ilhas no meio de um imenso oceano em que as rotinas vão, na grande maioria dos casos, no sentido contrário, o que torna o trabalho muito difícil e compromete substancialmente os próprios resultados. A implantação de novas experiências, a partir da coleta de dados descrita no terceiro capítulo, foi alvo da explanação realizada pelo pesquisador no estudo de caso, à medida que o 
desenvolvimento da virtualidade enquanto capacidade humana sugere realizações criativas, ousadas, inovadoras e até mesmo revolucionárias.

Baseou-se esta discussão também em Masetto (1998), para que o profissional docente da instituição de estudo de caso seja compreendido, assim como as alternativas que lhe são possíveis, na alteração da situação de monotonia no âmbito educacional. O autor aponta que, para corrigi-la, é possível a formação de novas equipes de professores, além de uma nova forma de agrupar alunos nas turmas ou cursos, com o apoio e colaboração efetivos dos órgãos de gestão da instituição, no sentido de mudar, transformar ou mesmo transmutar os seus modos de funcionar e trabalhar.

Por isso, os objetivos e conteúdos programáticos, no interior dos diferentes espaços disciplinares do plano de estudo, bem como os processos de organização, gestão, realização e avaliação, junto da utilização dos diversos contextos discentes e, sobretudo, a mobilização dos sujeitos, assumem um papel determinante neste processo de modificação. Na análise referente ao estudo de caso, tais elementos também foram considerados, inclusive, se os ideais da Escola Municipal Mário Covas, de acordo com os da Escola da Ponte, permitem aos educandos assimilarem o saber enquanto agentes mobilizadores do processo de ensino e aprendizagem.

Mencionou-se ainda Masetto (1998), para a compreensão da possibilidade de mudança no modo como os conteúdos são transmitidos pelas novas tecnologias; pois se esta mudança não se verificar em relação a estes fatores, tudo ficará na mesma, não obstante os esforços que se tenham despendido. Efetivamente, esta transformação ou transmutação, cada vez mais urgente a uma verdadeira mudança, verificando-se, inclusive, na instituição de estudo de caso, a necessidade de que tais mudanças ocorram, já que a mesma deseja adotar os métodos da Escola da Ponte. É também uma construção pessoal e social de conhecimento, em que é preciso atender a uma nova epistemologia que possibilite a criação de novos paradigmas, ao nível das concepções e das atitudes susceptíveis de consolidar uma nova cultura de escola, bem como uma maneira distinta de trabalhar as questões da aprendizagem, do ensino e do desenvolvimento de todos e de cada um dos seus atores.

$\mathrm{Na}$ análise da atuação dos professores da Escola Municipal Mário Covas, percebeu-se que mudanças sutis podem trazer grandes produções, e que uma nova cultura pode se originar do retorno à valorização das capacidades de criar e imaginar (VYGOTSKY, 2001). Esta nova cultura terá de ser mais eficaz do que a cultura tradicional, de contrário, não valeria a pena o esforço e o eventual incômodo ou desconforto. Em toda e qualquer transformação, porém, um objetivo que não pode nunca ser perdido de vista é a melhoria do sistema, no sentido de um 
maior e melhor sucesso de todos os seus atores e, designadamente, os docentes e discentes aprendentes.

Na intenção da instituição de estudo de caso em adotar as ideias da Escola da Ponte acompanhada de modo constante, em eventos específicos como a palestra do Prof. José Pacheco, assim como em análise do Projeto Político Pedagógico -, este modo de pensar sobre a união entre a virtualidade e as práticas pedagógicas faz-se fundamental, ainda mais considerado que isso estimula a criatividade das duas partes, ansiosas pelo saber (PACHECO, 2000). No Brasil, como em outros muitos lugares do planeta, existem experiências docentes e aprendentes que são verdadeiras construções pessoais e sociais ou de aprender e ensinar (MASETTO, 1998). Há elevado número de experiências de grande qualidade, realizadas ou em curso, nas diferentes escolas brasileiras que são verdadeiras construções pessoais e sociais de saberes, de conhecimento, de aprendizagens, de vida.

Mencionou-se também Dowbor (2001), para que seja estabelecida uma relação entre a virtualidade, estimulada pela educação, como forma de orientar a produção econômica e sociocultural de nosso país; pois o Brasil tem enormes capacidades, potencialidades e competências para transformar as instituições de ensino em verdadeiras comunidades aprendentes, que conduzam ao desenvolvimento de todos os seus atores e contribuam para o progresso efetivo da sociedade.

Surgem como inovações de esperança à instituição escolar como um todo, a ideia do ensino, da docência e da aprendizagem e dos processos de formação, investigação e inovação como uma grande construção pessoal e social, em que o conhecimento, a afetividade e a vontade assumem um papel determinante. Tal ideia será, inclusive, mencionada dentre o relato da coleta de dados, a partir do segundo capítulo; mas diante da falta de atividades que estimulem as capacidades criativas, deixa-se de se trabalhar com a virtualidade inerente ao educando, principalmente nos anos iniciais do Ensino Fundamental.

O envolvimento da pessoa humana como um todo no processo individual e coletivo da virtualidade é inerente ao desenvolvimento do saber, assim como a existência das políticas, das ideologias e dos contextos. Também a participação das escolas como comunidades aprendentes através de realizações mais partilhadas, criativas, eficazes, colaborativas, responsáveis e autônomas; o acesso aos meios e, designadamente, às novas tecnologias da informação e comunicação, de uma maneira mais inteligente e espontânea: 
Nenhuma formação docente verdadeira pode fazer-se alheada, de um lado, do exercício da criticidade que implica a promoção da curiosidade ingênua à curiosidade epistemológica, e do outro, sem o reconhecimento do valor das emoções, da sensibilidade, da afetividade, da intuição ou adivinhação. Conhecer não é, de fato, adivinhar, mas tem algo que ver, de vez em quando, com adivinhar, com intuir. $\mathrm{O}$ importante, não resta dúvida, é não pararmos satisfeitos ao nível das intuições, mas submetê-las à análise metodicamente rigorosa de nossa curiosidade epistemológica (FREIRE, 2002, p. 51).

Baseou-se em Lévy (1993), na busca por compreender como as informações obtidas por meio das novas tecnologias podem se tornar conhecimento, e o papel docente na orientação deste processo, dentro e fora da sala de aula, inclusive no que se refere à atuação dos professores da referida instituição de estudo de caso. Há a necessidade de adquirir outra visão da realidade e do mundo com base no ciberconhecimento, que possibilite a ciberaprendizagem, uma nova cultura que esteja voltada para a escola como local de produção de saber - conforme discutido durante explanação realizada pelo pesquisador no estudo de caso - e outras formas de ser, de estar, de agir e de comportar-se, além de todo este processo de conhecer, aprender e ensinar como verdadeira construção pessoal e social de conhecimento, de experiência, de ação e de vida.

Diante destas questões, fez-se relevante apontar as características existentes na instituição deste estudo de caso que permitem realizações voltadas ao uso das novas tecnologias, bem como o aprendizado realizado de modo eficaz, condizente com as experiências práticas dos alunos. Com a discussão sobre a presença da virtualidade, encontrada no ambiente apresentado pelas novas tecnologias, assim como o estímulo à criatividade que pode ser desenvolvido em âmbito pedagógico, faz-se mister também desenvolver uma discussão sobre como o virtual destaca-se no cotidiano discente.

O perfil do professor da Escola Municipal Mário Covas será detalhado no capítulo seguinte. Contudo, cabe apontar aqui algumas questões referentes ao modo como o docente da referida instituição de estudo de caso reconhece o virtual em meio a sua atuação: de acordo com os dados coletados, de um modo geral, os professores baseiam-se apenas na virtualidade apresentada pelas novas tecnologias. Ou seja, algo "pronto", que venha a precisar de pouca ou nenhuma intervenção para que se analise e compreenda em suas potencialidades, limitando-se aos jogos eletrônicos de caráter pedagógicos, ou mesmo softwares com alta qualidade gráfica, mas sem qualquer estímulo específico à criatividade e à imaginação (ASSIS, 2007).

Voltado para esta discussão, o foco a seguir estará voltado para os jogos eletrônicos, o processo de subjetivação que os caracteriza, e o modo pelo qual apresentam um universo 
totalmente novo, em sintonia com a imaginação infanto-juvenil, mas que podem ser estimulados de maneira a superar as expectativas dos educandos para com o fantástico e o criativo.

\subsection{O Virtual na Subjetivação dos Jogos Eletrônicos}

Para a devida compreensão das possibilidades docentes junto ao uso dos jogos eletrônicos como recurso ou mesmo base de discussões de saberes diversos, recorreu-se a Assis (2007) e Tenório (1998). De acordo com os autores, as concepções analisadas até o presente momento e as questões discutidas anteriormente - sobre a virtualidade e suas manifestações nas novas tecnologias -, será desenvolvido neste subtítulo um foco para com os jogos eletrônicos e os elementos que o caracterizam enquanto jogo, enquanto nova tecnologia, enquanto manifestação do virtual e fonte de ciberconhecimento, de acordo com concepções pedagógicas constatadas no estudo de caso.

Esta versatilidade de conteúdos reflete-se, inclusive, no comportamento humano, que se modifica à medida que as novas tecnologias são utilizadas para a divulgação de ideias e valores, fazendo com que, no ambiente virtual, seja projetada uma imagem idealizada, que é diferente da real por não exibir todas as características da pessoa, mas apenas as que ela deseja mostrar. Os jogos eletrônicos possuem presença marcante na vida dos educandos, em casa ou mesmo em lojas especializadas em games. Portanto, constatar as características do virtual neste meio, junto dos conteúdos nele desenvolvidos, é relevante para esta pesquisa, na medida em que os jogos eletrônicos também podem, de algum modo, contribuir para com o aprendizado, por meio da virtualidade que os mesmos apresentam.

A compreensão do modo como o ser humano visualiza a si mesmo e ao próprio ambiente, e sua compreensão por parte do profissional docente - principalmente na instituição de estudo de caso - envolve a análise da projeção de valores, que formam no virtual, uma imagem que o indivíduo idealiza e também faz parte do conceito de "sociedade do espetáculo": conceito movido pela aparência e pela crença de que um objeto ou ser que aparenta ser bom, seja bom (DEBORD, 2010). Como em um grande baile de máscaras, as pessoas não assumem a própria identidade, muitas vezes porque entram em um esquema de jogo, e utilizam-se da possibilidade de não serem vistas (a não ser que desejem, por meio de acessórios específicos para PCs, como a webcam), para "brincarem” em salas de bate-papo, sites de relacionamentos ou mesmo pessoais, adquirindo uma identidade que não é a delas, mas idealizada a partir do que gostariam de ser. 
Segundo Assis (2007), outras pessoas, em uma ação oposta a esse simples jogo, realizam tal projeção de valores e ideias por insegurança, ou mesmo por não aceitarem quem de fato são na vida real (ou atual). Neste caso, há o risco das TICs tornarem-se um verdadeiro refúgio para as mesmas, inclusive se for considerada a possibilidade de se levar para onde forem os recursos móveis da tecnologia digital. O destaque nesta questão da projeção do indivíduo em um ambiente virtual, utilizando-se de características e valores diferenciados, encontra-se nos videogames e seus jogos eletrônicos.

Utilizando-se da tecnologia digital e dos elementos virtuais, os jogos eletrônicos atuais oferecem a quem os joga, ambientes de interação e personagens complexos, para que o meio esteja pronto para ser apenas o condutor de um processo contínuo de responder aos estímulos que tal tipo de entretenimento realiza. Pode-se dizer que o videogame é um recurso que oferece a virtualidade em um nível máximo de possibilidades, limitando-se à criatividade do jogador ou às tecnologias utilizadas em sua fabricação (MENDES, 2007).

De acordo com a ideia de que as informações veiculadas pelas novas tecnologias devem ser discutidas e analisadas de maneira minuciosa, a fim de que contribuam para o processo de ensino e aprendizagem, também se deve considerar, segundo Tenório (1998), que pela possibilidade de se publicarem informações em grandes quantidades nas páginas virtuais dos sítios da Internet, muitas vezes esta ação é feita sem qualquer preocupação voltada ao método científico, ou mesmo sem ser verificada a autoria dos conteúdos. Com essa veiculação de dados sem normas ou critérios, devem ser analisadas, com muita atenção, as fontes para a realização de novas pesquisas, ou mesmo para uma consulta por curiosidade, pois nem tudo pode ser considerado como proveitoso para o processo de aprendizagem - afirmação discutida em meio à explanação realizada pelo pesquisador na escola deste estudo de caso.

É fundamental considerar neste ponto que, diante das afirmações anteriores, bem como com as constatações obtidas com a coleta de dados, de que a utilização das novas tecnologias, sem uma criteriosa avaliação dos conteúdos, por meio delas consultados, vem a ser não uma ferramenta de ensino e pesquisa, mas um obstáculo sedutor para deixar de considerar e reconhecer o que seja realmente científico e aproveitável para o seu aprendizado.

No processo de coleta de dados foi analisada a posição que usualmente os professores da Escola Municipal Mário Covas assumem, diante da necessidade em se trabalhar com o pensamento crítico, de que é fundamental incentivar em seus alunos a atitude de selecionar as informações, sem acreditar em tudo o que é divulgado nos sites, como também se reservando no direito de garantir a sua privacidade e segurança (assim como de quem o cerca), evitando, por 
exemplo, a divulgação exagerada de dados pessoais (e verídicos) nas páginas virtuais de relacionamento. Segundo Lévy (1993), o uso indevido dos recursos digitais conduz à banalização destes e da virtualidade em si, já que a apreensão de informações acaba sendo deturpada, sem que lhe seja dirigido um olhar crítico ou vinculada qualquer função voltada à aprendizagem, ficando a criatividade e imaginação dos alunos também comprometida.

As mídias que fazem parte das Tecnologias de Informação e Comunicação (TICs) podem complementar a atividade pedagógica, garantindo, por meio da ludicidade, que os conteúdos a serem aprendidos sejam desenvolvidos de maneira eficaz e inovadora. Entretido pelos recursos que as TICs oferecem, juntamente da própria realidade virtual, os conteúdos vistos em sala de aula ganham novos atrativos para quem aprende, sendo, de certa forma, enriquecedor poder contar com as novas tecnologias, para complementar atividades antes realizadas apenas pela linguagem oral ou escrita (TENÓRIO, 1998).

A estimulação de vários sentidos, ao mesmo tempo, é garantida nas tecnologias digitais, devido à capacidade multimídia que possuem. Os computadores e outros meios tecnológicos proporcionam a integração entre visão (imagens virtuais transmitidas pelo monitor de vídeo do PC), audição (sons e músicas executados e transmitidos pelas saídas de áudio, como as caixas acústicas), tato (contato existente com o PC pelo toque com os periféricos, como teclado, mouse, joystick e touchpad), além das imaginações (de quem elaborou o jogo e do jogador) e criatividade, estimuladas pelos recursos variados do próprio ambiente virtual (ASSIS, 2007).

Todos estes elementos, se forem devidamente considerados, podem ser estimulados de forma complementar ao aprendizado usual, sempre com foco voltado ao estímulo da criatividade e imaginação, de forma autônoma. Os jogos eletrônicos, portanto, podem ser considerados recursos pedagógicos eficazes, se o professor souber inserí-los em sala, em sintonia com os conteúdos a serem transmitidos ao longo do ano letivo. Possibilidade esta que veio a ser considerada pelos profissionais docentes da referida instituição de estudo de caso, de acordo com os dados coletados nesta parte específica da pesquisa.

A aquisição de informação deve ter o propósito de discussão de teorias e geração de um conhecimento realmente relevante em relação à geração que acompanha a "sociedade da informação" (NICOLA, 2004). Os conteúdos do ambiente virtual, portanto, devem ser selecionados e avaliados com critérios mais rígidos, como o método científico ou mesmo julgando-se a importância que um determinado assunto possui, em um momento específico. Torna-se valioso para o aluno, a partir deste processo, aprender pelo interesse em questionar e compreender um mesmo tema de diversas formas. 
Baseou-se em Assis (2007) para a compreensão de como os jogos eletrônicos se relacionam com o aprendizado do educando, já que envolve o contexto extraclasse do aprendizado, bem como a virtualidade, enquanto meio de entretenimento que gera um ambiente e enredo específicos, que estimulam a imaginação e a criatividade, mas não por completo. Os jogos eletrônicos, por se destacarem nesta questão do envolvimento pela ludicidade, podem também ser considerados recursos com fins pedagógicos, ao incluírem temas relevantes para o jogador de maneiras variadas, auxiliando na apreensão de conteúdos que colaboram com o desenvolvimento do saber.

Pode-se, por exemplo, segundo Lévy (1996), aprender História com um jogo eletrônico que o envolva em meio a diversos períodos, com contextos sociais e culturais próprios de cada tempo. Sentindo-se envolvido pelo contexto lúdico do virtual, o aluno volta a utilizar-se da interpretação por meio dos símbolos, re-significando o ambiente a sua volta, porém, desta vez, com diferentes e inúmeras possibilidades de interagir, e pela interação, aprender. A capacidade que o jogo eletrônico possui em subjetivação é extrema, pois o jogador é colocado em uma posição responsável pelas ações, decisões e consequências das mesmas em relação ao personagem principal, que está em seu comando (MENDES, 2006).

A ideia de o professor trazer esse meio para a sala de aula, de um modo criativo, pode muito bem ser uma proposta aceitável para atividades a serem realizadas pelos professores da Escola Municipal Mário Covas, considerando-se, inclusive, o ensejo da instituição de estudo de caso em adotar os princípios da Escola da Ponte. A virtualidade também se faz presente no jogo eletrônico, de uma maneira bilateral, pois a imaginação do jogador o auxilia na exploração de um mundo também imaginário (ASSIS, 2007). O aprendizado pode ser, em âmbito escolar, estimulado neste sentido, promovendo-se a virtualidade nas instâncias humana e tecnológica para que os conteúdos possam ser devidamente explorados pelos alunos, garantindo-se também que a subjetividade influencie-os à assimilação pessoal de tudo o que é apresentado.

Esse mesmo envolvimento pode conduzir ao que se denomina vício, que no caso do videogame vem a ser a necessidade de explorar de maneira exagerada pelo jogador, numa substituição das necessidades reais - fisiológicas, mentais e psicossociais - pelas virtuais, transmitidas por meio de um ambiente que, sequer, precise ser gerado pela primeira virtualidade: basta que o jogador mergulhe no que já que foi imaginado por outrem, limitando-se a explorar o virtual em sua segunda instância, a tecnológica. Nesta proposta de análise por parte do profissional docente, destaca-se que as informações apreendidas por meio dos jogos eletrônicos 
também trazem elementos que podem contribuir para com o aprendizado, a partir do ambiente virtual específico que é apresentado ao jogador neste meio de entretenimento.

Segundo Tenório (1998), no que diz respeito, portanto, à atitude de pais e educadores para com o jogo eletrônico, refere-se à utilização moderada dos mesmos, conjugada à vertente educacional que tal recurso pode vir a apresentar. Como discutido anteriormente - e conforme apresentado na explanação do pesquisador ao corpo docente da instituição de estudo de caso, conforme relatado no segundo capítulo - conteúdos curriculares podem ser trabalhados no formato do jogo eletrônico, constituindo-o como meio complementar às aulas.

Conforme discussão realizada na dissertação até este ponto, é relevante apontar que o professor em suas aulas tem a possibilidade de, por exemplo, estimular outras formas de interagir com o aprendizado, principalmente a leitura. Esta, em oposição à criatividade pronta dos videogames, mostra-se riquíssima no desenvolvimento da virtualidade humana, pois ao leitor é oferecido apenas um roteiro, para que os diversos elementos nele presentes sejam, então, gerados como em um ambiente virtual na imaginação. Assim sendo, no próximo item desta pesquisa serão destacadas, de modo sintetizado, as possibilidades futuras para o ensino, oriundas das realizações em conjunto dos profissionais da educação e da aplicabilidade das novas tecnologias, em meio às diversas realizações que são cabíveis também à instituição de estudo de caso.

\subsection{Projeções para o Futuro da Educação no Brasil}

De acordo com os dados coletados, a Escola Municipal Mário Covas, diante da possibilidade de adoção das práticas e filosofia da Escola da Ponte, voltadas às suas realizações, possui uma gama variada de oportunidades para a ação pedagógica, junto às novas tecnologias como também em relação ao contexto de seus educandos junto à virtualidade - tanto a que é presente nos recursos digitais de comunicação e entretenimento, como a que se utilizam constantemente, inclusive para tornarem-se integrantes da realidade apresentada por tais meios, já que cada realidade possui necessidades específicas, mas todas contam com o princípio educacional, em seus vários módulos. A educação junto às novas tecnologias situa-se, sem dúvida, na chamada "terceira onda", que inclui os fenômenos próprios da cibercultura e da sociedade do conhecimento: 
que seus ancestrais faziam há centenas de anos, produzindo só o necessário para sobreviver. O Brasil da segunda onda é visto em São Paulo e em várias outras regiões do país, com grande urbanização, muitas indústrias, engarrafamentos e poluição. E também é possível encontrar no Brasil, de uma forma ainda incipiente, uma parte da sociedade que já vive a terceira onda. São pessoas que estão na internet, usam computadores de forma rotineira e têm empregos que exigem um conhecimento cada vez mais sofisticado. O Brasil é um país heterogêneo, cultural e racialmente, e hoje também comporta três estruturas econômicas diferentes (TOFFLER apud GOMES, 2007, p. 03).

A sentença de Toffler (GOMES, 2007) revela que a complexidade brasileira, no âmbito educacional, pode e deve ser trabalhada de modo diversificado, respeitando-se a heterogeneidade inerente ao processo histórico e cultural de formação do país, afirmação reconhecida inclusive na análise dos dados coletados, conforme conteúdo apresentado no segundo capítulo. A informação, pela sua quantidade e complexidade de utilizações, tem de ser reorganizada por quem a procura, trabalhada por quem deseja transformá-la em conhecimento e interpretada como uma competência, algo que auxilie no desenvolvimento da capacidade criativa do indivíduo. E se a capacidade reflexiva é inata no ser humano, esta necessita de contextos que favoreçam o seu desenvolvimento, como "contextos de liberdade e de responsabilidade, vencendo inércias com vontade e persistência" (ALARCÃO, 2003, p. 13).

A ideia desta pesquisa de desenvolver uma discussão sobre a virtualidade promoveu, de forma inerente, a importância de desenvolver-se, na atuação docente da instituição de estudo de caso, atividades que contribuam para o desenvolvimento do educando, voltadas a elementos que se relacionem a esta capacidade humana - hoje modificada e ampliada nas novas tecnologias. Os jogos eletrônicos, desde que não sejam consumidos de forma banal, são passíveis de uma análise, fomentada pelo professor, em relação ao contexto que tal meio de entretenimento promove junto à virtualidade do aluno.

A educação à distância também promove estes contextos, a partir do momento em que o educando possui uma liberdade que é paralela à responsabilidade, utilizando-se de seu tempo de maneira singular, mas coordenando-o diante da vontade de aprender e desenvolver-se intelectualmente. A ideia principal, portanto, reside no fato de que a educação à distância pode ser utilizada também como complemento das aulas usuais. Questão essa que é considerada pelos professores da referida escola de estudo de caso, como forma de, em acordo com as ideias da Escola da Ponte, elaborar atividades que utilizem em conjunto as novas tecnologias e o aprendizado efetivo: 
É um saber-fazer sólido, teórico e prático, inteligente e criativo que permite ao profissional agir em contextos instáveis, indeterminados e complexos, caracterizados por zonas de indefinição que de cada situação fazem uma novidade a exigir uma reflexão e uma atenção dialogante com a própria realidade que lhe fala (ALARCÃO, 2003, p. 27).

Perante a multiplicidade de sentidos que possui o aprendizado, diante da chamada "era do conhecimento" (LÉVY, 1993; 1996), faz-se necessário ao professor que estabeleça a apreensão de informações - com sua consequente transformação em competências - como escolha legítima do aluno, sem exigências curriculares imutáveis, trabalhando-se a concepção de educação de acordo com o comportamento da sociedade. A sociedade que, afinal, também possui a missão de educar, derrubando a errônea cobrança exclusiva em relação à escola, já que esta é uma das instituições responsáveis dentre a família, a municipalidade e a comunidade em geral, que colaboram com a formação do ser humano.

As questões apresentadas no primeiro capítulo desta dissertação refletem uma discussão teórica relevante sobre a virtualidade, no sentido de que se apresentam concepções sobre como o ser humano utilizou-a em suas capacidades mentais para a elaboração da linguagem, por meio da mediação simbólica do mundo. Do mesmo modo, a assimilação de conteúdos segue o mesmo processo, com participação efetiva do virtual, ainda mais se considerando o seu uso por meio das novas tecnologias.

Ao longo da primeira parte deste primeiro capítulo, foi analisada a importância da mediação simbólica para com a geração de significados, e a utilização dos mesmos para com a assimilação do conhecimento foram discutidas. O emprego ideal da virtualidade no contexto educacional, principalmente na escola analisada como estudo de caso nesta pesquisa, é a união dos recursos tecnológicos - a exemplo dos softwares, jogos eletrônicos e ambientes virtuais de aprendizagem, cenário da educação à distância - com o estímulo da criatividade, com base na imaginação, em meio às realizações pedagógicas. Estes procedimentos serão os considerados no segundo capítulo, em meio à instituição de estudo de caso, a Escola Municipal Mário Covas, em meio à aplicação das idealizações e realizações da Escola da Ponte. 


\title{
CAPÍTULO II - A REALIDADE DO PONTO DE VISTA DOCENTE: ESTUDO DE CASO NA ESCOLA MUNICIPAL GOVERNADOR MÁRIO COVAS JÚNIOR
}

\author{
“É vital disponibilizar amplas redes de comunicação \\ para transformar a educação num processo \\ interativo de enriquecimento mútuo”.
}

(Ladislau Dowbor, 2001).

\section{INTRODUÇÃO AO ESTUDO DE CASO}

Como metodologia de pesquisa, realizou-se um estudo de caso, cujo propósito foi analisar o contexto de uma instituição pública de ensino, em suas ideologias e realizações cotidianas, relatando-as nesta parte específica da dissertação.

A instituição pública selecionada foi a Escola Municipal Governador Mário Covas Júnior, situada no município de Ubatuba, litoral norte de São Paulo. A escolha da instituição foi devido a existência de um laboratório de informática que disponibiliza recursos mais que suficientes para a realização de uma alfabetização digital, além de ser uma das escolas do município que visa a aderir às ideologias da Escola da Ponte, propagadas por José Pacheco.

\subsection{Definições de Estudo de Caso}

Consideraram-se as teorias de Malinowski (1976) em relação à Etnografia, para que fosse confirmada a importância de se realizar um estudo de caso. De acordo com o autor, deve-se buscar estudar o diferente em seus próprios meios e encará-lo segundo a lógica da sua própria visão cultural de mundo, sem deixar que a visão subjetiva do pesquisador venha a "contaminar" os dados e relatos coletados das observações para com outrem. Segundo o autor, deve-se ter um respeito ao outro em seus próprios termos, definido por ele como o ato de:

(...) permitir distinguir claramente, de um lado, os resultados da observação direta e das declarações e interpretações nativas e, de outro, as inferências do autor, baseadas em seu próprio bom-senso e intuição psicológica. (...) Na etnografia, é frequentemente imensa a distância entre 
a apresentação final dos resultados da pesquisa e o material bruto das informações coletadas pelo pesquisador através de suas próprias observações (...) (MALINOWSKI, 1976, p. 22-23).

Um estudo de caso pode ser definido como um meio de análise da realidade social, possibilitando ao pesquisador "organizar dados sociais preservando o caráter unitário do objeto social estudado" (DUARTE; BARROS, 2006, p. 216). Fez-se necessário, portanto, que após a discussão aprofundada das possibilidades educacionais, diante da exploração do virtual em todos os seus aspectos relevantes, fosse considerada a possibilidade de escolha de uma instituição como estudo de caso, para a avaliação da importância que a educação possui em sua filosofia, além da devida análise voltada aos recursos didáticos e tecnológicos que costumam ser empregados em suas aulas. Portanto, preserva-se o que será investigado como um todo, apreendendo-se deste as informações detalhadas para o devido complemento da pesquisa científica.

Para a devida coleta de dados, a fim de que se apreendesse a totalidade de uma situação, Bruyne, Herman e Schoutheete sugerem o uso de técnicas de coleta de informações igualmente variadas e refinadas, como observação participante - método específico de coleta, em que entrevistador e grupo pesquisado realizam uma troca aprofundada de informações -, entrevistas de caráter sociométrico - que tem como objetivo investigar e mensurar as relações interpessoais - entrevistas de caráter etnográfico -, que diz respeito aos aspectos sócio-culturais de um grupo social (DUARTE; BARROS, 2006, p. 216).

Quanto à tipologia, o estudo de caso pode ter um intento de exploração na descoberta de problemáticas novas e na renovação de perspectivas existentes; outros são essencialmente descritivos, tomando a forma de uma monografia, na descrição da complexidade de um caso concreto sem a pretensão de obter o geral; como também há outros que perseguem um objetivo prático e utilitário, na tentativa de estabelecer um diagnóstico de uma organização ou realizar sua avaliação (DUARTE; BARROS, 2006, p. 217).

Quanto às suas quatro características essenciais, o estudo de caso pode centrar-se em uma situação, acontecimento, programa ou fenômeno particular, sendo uma via de análise prática de problemas da vida real, constituindo isto o particularismo; seu resultado é a descrição detalhada de um assunto submetido à indagação, sendo esta a descrição; ajuda ainda a compreender àquilo que submete à análise, compreendendo novas visões, interpretações e perspectivas, caracterizando a explicação; por fim, a maioria dos estudos de caso utiliza o raciocínio indutivo 
em suas análises, segundo o qual os princípios emergem dos dados particulares, sendo esta por sua vez a indução (DUARTE; BARROS, 2006).

Os registros referentes ao estudo de caso foram feitos por meio de um diário de campo, no qual se procurou registrar as atividades relacionadas ao estímulo da criatividade e da imaginação dos educandos, principalmente se fosse utilizado como complemento o computador, para que fossem consideradas todas as realizações pedagógicas em que estivesse presente o virtual.

Estes dados coletados foram somados aos obtidos por meio de questionários quantitativos e qualitativos; respectivamente, foram os recursos de sondagem sobre o uso das novas tecnologias e as questões dissertativas sobre a ideia docente sobre a virtualidade, além da consideração sobre o ensejo da instituição em adotar as ideias da Escola da Ponte.

Por ora, cabe então classificar o estudo de caso referente a esta pesquisa, quanto a sua tipologia, como a de uma análise que persegue um objetivo prático: o de verificar o modo como a virtualidade é estimulada nas atividades pedagógicas, tanto nas atividades com o uso de computadores como em outras elaboradas pelos docentes, por meio da análise de uma instituição responsável pela educação em âmbito municipal.

O foco foi direcionado à instituição analisada em função da elaboração de uma descrição detalhada, para que ela pudesse ser compreendida sob novas perspectivas, tendo seus princípios confirmados em relação aos preceitos particulares da Escola da Ponte e colocando sua posição epistemológica e metodológica, diante dos aspectos discutidos anteriormente em relação ao papel da virtualidade no âmbito pedagógico.

\subsection{Reflexões acerca das Ideologias de José Pacheco e a Escola da Ponte}

A E. B. I. Aves / São Tomé de Negrelos, popularmente referida apenas como Escola da Ponte, é uma instituição pública de ensino, localizada em Vila das Aves, no Distrito do Porto, em Portugal. É uma Escola Básica Integrada, encontrando-se seus alunos inscritos formalmente por anos de escolaridade - do $1 .^{\circ}, 2 .^{\circ}$ e $3 .^{\circ}$ Ciclos do Ensino Básico -, ainda que esta divisão administrativa não se reflita nem no seu Projeto Educativo, nem no seu trabalho quotidiano.

Embora a faixa etária dos alunos compreenda aproximadamente dos cinco aos dezesseis anos de idade, devido à sua filosofia de educação inclusiva possui, no entanto, alguns alunos 
mais velhos. Atualmente conta com cerca de cento e oitenta alunos e vinte e nove orientadores educativos (ESCOLA, 2010).

A instituição surgiu na década de 1970, do desejo de se fazer uma escola que respeitasse as diferenças individuais dos alunos. Em 1976, as respostas a algumas interrogações deram origem a profundas mudanças na organização da escola, na relação entre ela, instituição, e os encarregados de educação dos alunos - o que se refere geralmente, mas não exclusivamente aos pais - e nas relações estabelecidas com diferentes parceiros locais.

A escola encontra-se numa área aberta. Os alunos formam grupos heterogêneos, não estando classificados, agrupados ou distribuídos por turmas nem por anos de escolaridade que, na prática, não existem. Não há salas de aula, mas sim espaços de trabalho, onde não existem lugares fixos. Essa subdivisão foi substituída, com vantagens, pelo trabalho em grupo heterogêneo de alunos. Do mesmo modo, não há um professor encarregado de uma turma ou orientador de um grupo; em vez disso, todos os alunos trabalham com todos os orientadores educativos (ESCOLA, 2010).

A escola está organizada por três núcleos: iniciação, consolidação e aprofundamento. Os orientadores estão organizados por dimensões artística, identitária, linguística, lógico-matemática e naturalista:

Definição dos Direitos e Deveres - a cada ano, os alunos decidem democraticamente, na Assembleia de Escola, os direitos e deveres que consideram fundamentais para aquele ano.

Assembleia de Escola - atividade que reúne todos os alunos e professores, na qual são discutidas, analisadas e votadas medidas para problemas na escola, de forma democrática, solidária, respeitando as regras e visando ao bem comum.

Comissão de Ajuda - é formada por quatro alunos nomeados para resolver os problemas mais graves colocados na Assembleia. Dois desses alunos são escolhidos pelos membros da mesa da Assembleia Geral e outros dois pelos professores. As decisões dessa Comissão se guiam pelos direitos e deveres definidos pelos alunos, que se comprometeram a respeitar o estabelecido. 
Debate - tem caráter mais informal que as Assembleias e acontece todos os dias excetuando-se os dias de Assembleia Geral -, possuindo duração de trinta minutos. Destina-se à discussão sobre o que se fez durante o dia de trabalho, através de jogos de perguntas e respostas. É nessa ocasião que são preparadas as Assembleias.

Biblioteca - ocupa o espaço comum, da área aberta da Escola, e serve como espaço de encontro e de pesquisa.

Caixinha dos Segredos - local destinado ao desabafo das crianças, que ali depositam seus segredos, que muitas vezes revelam as razões da chamada indisciplina.

Caixinha dos Textos Inventados - local sempre disponível a receber as criações textuais imaginativas dos pequenos.

Eu Já Sei - faz parte do objetivo de desenvolver a autonomia dos alunos, partindo do processo de autoavaliação. A criança então escreve seu nome numa lista, informando o que já considera que aprendeu e está pronta para ser avaliada por um professor. Só então essa avaliação processa-se.

Eu Preciso de Ajuda - a criança é estimulada a buscar todas as fontes possíveis de informação que estão ao seu alcance antes de pedir ajuda. Esgotando suas possibilidades, o aluno pode escrever seu nome numa das listas dispostas em diversos locais da escola. Posteriormente, um professor organiza pequenos grupos de estudo para esclarecer o assunto com quem tem dúvidas.

Professor Tutor - o professor tutor acompanha de perto um grupo de oito a onze alunos, os quais monitora o trabalho individualmente e faz reuniões sistemáticas uma vez por semana, mantendo também um contato estreito com os encarregados de educação. 
Grupos de responsabilidade - cada aluno e a maioria dos orientadores educativos são responsáveis por algum aspecto do funcionamento da escola. Os grupos reúnem-se uma vez por semana para resolver alguns assuntos e elaborarem propostas para decisão em Assembleia. Algumas das responsabilidades atribuídas aos grupos são: Assembleia e Comissão de Ajuda; Terrário Jardim; Clube dos Limpinhos; Refeitório; Arrumação e Material Comum; Direitos e Deveres; Biblioteca; Jornal; Correio e Visitas na Ponte; Jogos de Mesa; Computadores e Música; Desporto Escolar; Recreio Bom; Murais, Mapas de Presença e Datas de Aniversário (ESCOLA, 2010)

Resumidamente, são esses os elementos que caracterizam a Escola da Ponte, em suas concepções pedagógicas e, principalmente, na forma como a relação entre professores tutores e alunos é construída. O estímulo à virtualidade destaca-se no rompimento de paradigmas institucionais, que vão desde a formação de grupos heterogêneos à forma como todas as realizações passam pela análise dos alunos - dentre os debates, assembleias, autoavaliações e grupos de responsabilidade -, fazendo com que eles sejam agentes não apenas do processo de ensino e aprendizagem, mas de toda a parte operacional da escola.

Dessa forma, o virtual ganha espaço, na medida em que novos desafios são propostos aos discentes, a criatividade e a imaginação são colocadas para agir, em prol de novas concepções, ou mesmo na reflexão de questões do cotidiano. Assim sendo, as capacidades relevantes ao desenvolvimento do saber individual efetivam-se por meio das ações e discussões feitas em meio ao coletivo, complementando-se a tais ensinamentos a ideia de igualdade e uma ética voltada aos princípios pertinentes ao grupo. Além disso, há atividades programadas com computadores, o que permite também o acesso ao virtual enquanto manifestação visual das realizações humanas, por meio das tecnologias digitais.

Segundo Pacheco (2000), a responsabilidade aliada à criatividade é um dos recursos mais eficazes para se lidar com as dificuldades de adaptação dos alunos, inclusive, com o problema da indisciplina. Uma observação concernente ao objeto desta pesquisa seria a de que, com a virtualidade sendo desenvolvida de forma inerente à criatividade e reflexão dos alunos, a Escola da Ponte demonstrou (e demonstra) a maneira ideal para com o aprendizado eficaz, realizado de acordo com o contexto de seus alunos, envolvendo não os conteúdos prontos e a transmissão injustificada dos mesmos, mas sim, a proposta de que tudo pode ser dinâmico, acompanhando o ritmo com que a mente humana decifra novos códigos e descobre novas informações. 
A fim de que se realizasse uma análise conjunta da Escola da Ponte em relação à Escola Municipal Mário Covas, ainda mais depois de considerada a parceria pedagógica entre as duas instituições, o tópico a seguir comparou-as, apresentando as propostas realizadas pelo Prof. José Pacheco à Direção e Coordenação da escola deste estudo de caso, destacando o modo como a virtualidade pode ser estimulada em relação ao corpo discente desta.

Como complemento, foi transcrita a entrevista concedida por Pacheco ao autor desta pesquisa e às gestoras da E. M. Mário Covas, com a apresentação da instituição e de outros elementos específicos, conforme descrição realizada neste subtítulo, além de outros detalhes que foram registrados a seguir.

\subsection{A Idealização de uma Parceria Pedagógica: Escola da Ponte e E. M. Governador Mário Covas Júnior}

Após uma breve apresentação dos elementos que envolveram o pensar e o agir na Escola da Ponte, incluindo o destaque dado ao modo com que o aluno é estimulado em sua criatividade e reflexão crítica, a partir deste ponto será discutido o modo com que a Escola Municipal Mário Covas pretende adotar as concepções pedagógicas de José Pacheco, abrangendo diversos momentos relacionados à aprendizagem. Para iniciar, foram apresentadas perguntas feitas ao Prof. Pacheco em visita à instituição deste estudo de caso (vide Apêndice A), como forma de destacar as características da escola e mostrar o que pôde (e o que será) aplicado da Escola da Ponte na E. M. Mário Covas, principalmente enquanto forma de estímulo à virtualidade:

Segundo o Prof. Pacheco, na Escola da Ponte não há séries, ciclos, turmas, anos, manuais, testes e aulas. Os alunos agrupam-se de acordo com os interesses comuns para desenvolver projetos de pesquisa. Há também os estudos individuais, que são depois compartilhados com os colegas. Os estudantes podem recorrer a qualquer professor tutor para solicitar suas respostas. Se estes não conseguem responder, os estudantes são então encaminhados a um especialista. Não há salas de aula, e sim lugares onde cada aluno procura pessoas, ferramentas e soluções, testa seus conhecimentos e convive com os outros. São chamados de espaços educativos. Hoje, eles estão designados por área. Na humanística estuda-se História e Geografia; no pavilhão das ciências fica o material sobre Matemática; e o central abriga a Educação Artística e a Tecnológica. 
O sonho do Prof. Pacheco, com relação à arquitetura da Ponte, é um prédio com outro conceito de espaço. Uma maquete feita por doze arquitetos, ex-alunos que conhecem a proposta da escola, é a base deste sonho. Seu projeto inclui uma área que chama de "Centro da Descoberta", onde compartilharão o que souberem. Há também pequenos nichos hexagonais, destinados aos pequenos grupos e às tarefas individuais. Estão previstas ainda amplas avenidas e alguns cursos d'água, onde se possa mergulhar os pés para conversar, além de um lugar para cochilar. As novas tecnologias da informação devem estar espalhadas por todos os lados, para serem democraticamente utilizadas pela comunidade - havendo neste ponto a confirmação de que a virtualidade da criação e do uso das TICs realmente são focos de atuação da Ponte.

Os professores da Ponte têm a mesma formação que os de outras instituições. O diferencial é que sentem uma inquietação quanto à educação e admitem existir outras lógicas. A escola é a única no país que pode escolher o corpo docente. Os candidatos aparecem geralmente como visitantes e perguntam o que é preciso para dar aulas lá. O Prof. Pacheco pede apenas para deixarem o nome. No fim de cada ano são feitos os contatos, sendo que atualmente a instituição conta com vinte e sete profissionais, cada um com suas especializações. Há profissionais que estiveram sozinhos em sala durante anos e quando chegam à Escola da Ponte constatam que sua formação e experiência para nada servem. De cada dez que entram, um não aguenta. Outros desertam e regressam depois.

Contudo, mesmo os professores antigos também necessitam de adaptação. Há dois anos a Ponte recebe muitas crianças e professores novos, não familiarizados com a proposta da instituição. Apenas a quinta parte do corpo docente já estava lá quando isso aconteceu, quando passaram a conviver com mestres que sabiam dar aula e estudantes que sabiam fazer cópias. Foi necessário dar dois ou três passos para trás para que depois caminhassem todos juntos.

Os alunos da Ponte têm entre cinco e dezessete anos. Cerca de cinquenta (um quarto do total) chegaram extremamente violentos, com diagnósticos psiquiátricos e psicológicos. As instituições de inserção social que acolhem crianças e jovens órfãos os encaminham para as escolas públicas. Normalmente eles acabam isolados no fundo da classe e, posteriormente, são encaminhados para a Escola da Ponte. No primeiro dia, segundo o Prof. Pacheco, "chegam dando pontapés, gritando, insultando, atirando pedras. Algum tempo depois desistem de ser maus e admitem uma das duas hipóteses: ser bom ou ser bom”.

Em relação à adaptação ao método da Ponte, há crianças e jovens que chegam e não sabem o que é trabalhar em grupo. Não conhecem a liberdade, e sim, a permissividade. Não sabem o que é solidariedade, somente a competitividade. São ótimos, mas ainda não têm a 
cultura cultivada pela instituição. Quando se deparam com a possibilidade de definir as regras de convivência, que serão seguidas por todos, ou não decidem nada ou o fazem de forma pouco ponderada. Só para citar um exemplo, o professor disse que receberam um garoto de quinze anos, agressor do próprio professor, deixando-o em estado de coma, e o mesmo aluno teria de colaborar com a elaboração de um sistema de direitos e deveres.

Em 1976, havia na Ponte três educadores e noventa estudantes. Em vez de cada docente adotar uma turma de trinta, foram todos reunidos. O objetivo deles era promover a autonomia e a solidariedade. Antes disso, porém, os pais foram chamados, o projeto foi explicado e eles foram questionados sobre o que pensavam sobre o assunto. Eles apoiaram e defendem o modelo até hoje. Participam de todas as decisões e também defendem a escola perante o governo. Portanto, se o governo discordar de tudo aquilo que é feito pela Escola da Ponte, defronta-se com este obstáculo: os pais. Eles são a garantia de que o projeto vai continuar.

Há uma grande resistência na aceitação do modelo, o qual é baseado em três grandes valores: a liberdade, a responsabilidade e a solidariedade. Algumas pessoas consideram que todos precisam ser iguais e que ninguém tem direito a pensamento e ação divergentes. Há quem rejeite a proposta por preconceito, mas a diferença é que nenhum trabalho é colocado em cheque pelos profissionais da Ponte. Consideram que quem os ataca faz isso porque não foi aluno deles e não aprendeu a respeitar o ponto de vista alheio.

Acreditam que um projeto como a Escola da Ponte só é viável quando todos reconhecem os objetivos comuns e se conhecem. Isso não significa apenas saber o nome, e sim ter intimidade, como em uma família. É nesse ponto que o projeto se distingue. O viver em uma escola é um sentimento de cumplicidade, de amor fraterno. Todos que visitam a Ponte dizem que ficam impressionados com o olhar das pessoas que ali estão, com o afeto e a palavra terna que trocam entre si.

A ideia de modelos não é defendida pelo Prof. Pacheco, sendo que para ele a Escola da Ponte fez o que as outras devem e podem fazer, que é produzir sínteses e não se engajar em um único padrão. "Não inventamos nada. Estamos em um ponto de redundância teórica. Há muitas correntes e quem quer fazer diferente tem de ter mais interrogações do que certezas", disse o professor. Segundo ele, a Escola da Ponte não é duplicável e não há, felizmente, clonagem de projetos educacionais. No caso da Escola Municipal Mário Covas, a ideia de adotar ideias e práticas pedagógicas da Ponte não deve ser considerada cópia de uma instituição exemplar, mas antes uma troca de ideias, em busca da formação de um aluno criativo, reflexivo e crítico. 
O Prof. José Pacheco considera-se como um intermediário, sem chamar a atenção para méritos em relação à Escola da Ponte. Vai se afastar dentro de um ano e depois quer continuar “desassossegando os espíritos, em lugares onde há gente generosa, que só precisa de um louco com a noção da prática”, segundo o próprio. “Agora, ninguém pode dizer que uma experiência como a da Escola da Ponte não aconteceu, porque ela existe e provamos que é possível”, completou ao fim da entrevista o Prof. Pacheco.

A partir das declarações feitas pelo Prof. José Pacheco, podem ser complementadas as questões do subtítulo anterior, a respeito da Escola da Ponte possuir um método que estimula os elementos voltados à virtualidade do aluno, bem como sua autonomia e participação no processo de desenvolvimento de seu aprendizado. Interessante notar as observações feitas pelo idealizador da Ponte, no que diz respeito às dificuldades dos educandos ao entrarem na instituição, deles trabalharem em grupo e realizar decisões que irão orientar a todos os alunos, durante pelo menos aquele ano letivo.

Isso se coloca como um exemplo do que ocorre quando os alunos são disciplinados - ou melhor dizendo, doutrinados - em meio à pedagogia tradicional: a capacidade virtual perde sua força em meio à normas previamente apresentadas, cuja aceitação acaba sendo algo colocado como a única escolha por parte de todos os envolvidos no processo de ensino e aprendizagem.

Na adoção destes elementos pedagógicos revolucionários, advindos da Escola da Ponte, a Escola Municipal Governador Mário Covas Júnior terá como obrigação transformar diversas concepções em relação à gestão e currículo aplicados até então na referida instituição. Afinal, a estrutura da escola, até a coleta de dados e a conclusão desta pesquisa, estava ainda pautada pelo tradicionalismo, com as turmas divididas em classes, do $1 .^{\circ}$ ao $5 .^{\circ}$ ano, com poucas iniciativas voltadas à interdisciplinaridade - faltando para com esta questão, inclusive, orientações da própria coordenação, no que diz respeito ao modo como a integração entre disciplinas poderia ser fomentada.

A indisciplina, principalmente, ainda é tratada como um problema cuja responsabilidade é colocada exclusivamente como sendo do professor, pois ainda existe a crença, de um modo geral, de que esse deve possuir o controle total da classe, supervisionando, inclusive, as atitudes individuais dos alunos, a todo instante - quando na verdade, a aula se dá como um processo, em que o discente possui sua responsabilidade, bem como os elementos externos, que a influenciam de maneira significativa (FREIRE, 2002). 
Como também afirmou o Prof. José Pacheco, em sua entrevista para o autor desta pesquisa, junto das gestoras da Escola Municipal Mário Covas, a Escola da Ponte não pode nem é possível de ser copiada, pois foi um caso pioneiro, realizado de acordo com necessidades e um contexto específico. O mérito de Pacheco e de todos os professores que participaram e participam do projeto pedagógico adotado pela Ponte está nesse quesito, de que o contexto da Vila das Aves foi e é considerado, e tudo o que era e o que vem a ser necessário para que os educandos da referida comunidade sejam agentes do próprio aprendizado, envolvendo o modo como apreendem e utilizam as informações, foi e é trabalhado como prioridade na atuação docente.

Desse modo, verificou-se que o estímulo à virtualidade dos educandos foi colocado, desde o início da Escola da Ponte, como uma maneira de garantir o desenvolvimento individual e subjetivo do saber. Afinal, o virtual em si é uma capacidade mental única e referente a cada indivíduo, assumindo as características de como ele apreende e interpreta aquilo o que se encontra ao seu redor. Assim sendo, fez-se necessário que o item a seguir trouxesse a realidade da instituição deste estudo de caso, apresentando elementos pedagógicos e socioculturais, de forma que tais contextos pudessem, desde o início, serem analisados conforme o são verdadeiramente: complementares um ao outro, em meio ao cotidiano de professores e alunos.

Foram apresentados dados referentes ao município de Ubatuba, especificamente ao bairro do Ipiranguinha, para que as descrições sobre tais macroambientes pudessem ser referência na análise do microambiente; no caso, a referida escola deste estudo de caso. Voltando-se o foco para a Escola Municipal Mário Covas, diversos detalhes foram considerados no relato deste estudo de caso: desde a estrutura física da instituição, assim como os alunos e profissionais envolvidos nas atividades cotidianas, incluindo-se a análise destas atividades e se as mesmas estimulam de maneira eficiente a virtualidade dos envolvidos, conforme se espera de uma instituição que possui o ensejo de adotar os pensamentos e atitudes aplicados até então na Escola da Ponte. 


\section{O ESTUdO DE CASO: A ESCOLA MUNICIPAL GOVERNADOR MÁRIO COVAS JÚNIOR}

\subsection{Descrição da Escola Municipal Governador Mário Covas Júnior}

A instituição está localizada no município de Ubatuba, litoral norte de São Paulo. Possui cento e duas praias, e sua população, segundo o IBGE (2010) é de 78.870 pessoas. Cerca de $83 \%$ do seu território estão localizados no Parque Estadual da Serra do Mar. A Escola Municipal Mário Covas situa-se especificamente à Rua Açaís, n. ${ }^{\circ}$ 30, no bairro do Ipiranguinha. Funciona nos períodos da manhã e da tarde, respectivamente nos horários de sete às onze e meia e das treze às dezessete e meia. Possui enquanto níveis de atendimento o Ensino Fundamental nos ciclos I e II, do $1 .^{\circ}$ ao $5 .^{\circ}$ ano.

A escolha da escola se justifica por sua possibilidade de contribuição para com a inclusão digital de seus alunos, sendo equipada com um dos melhores laboratórios de informática dentre as escolas do município, segundo Projeto Político Pedagógico da instituição do ano de 2010, e dados específicos da Secretaria Estadual de Educação (SECRETARIA, 2010). Por meio de um questionário com questões abertas, foi avaliada com os professores a concepção que os mesmos possuem para com a virtualidade, tanto em suas funções como para com o processo de ensinoaprendizagem.

A concepção pedagógica da instituição está fundamentada nas teorias de Jean Piaget e Lev Vigotsky, considerando-se que ambos estudaram a relação entre aprendizagem e desenvolvimento, mas também se baseia em Wallon, Freire e Gardner, no que diz respeito ao estímulo das capacidades do educando (SECRETARIA, 2010). Segundo o mesmo documento, a escola, na teoria de Vigotsky e Piaget, observa e trabalha atividades respeitando o ritmo de aprendizagem de cada educando, em Wallon trabalha o contato entre os alunos e as atividades coletivas, em Freire a autonomia na aprendizagem, onde o individuo participa das aulas inserindo conteúdos de sua realidade e por fim Gardner, priorizando as inteligências de cada indivíduo. Tal perspectiva do autor coloca a criança como o centro dos processos de aprendizagem, atribuindo a ela um papel ativo na aquisição do conhecimento.

De acordo com tal documentação (SECRETARIA, 2010), nesta instituição o professor tem como papel mediar tais processos, interferindo sem dar as respostas aos alunos e sim mostrando os caminhos, o indivíduo tem como papel encontrar os conhecimentos e saberes 
(FREIRE In SECRETARIA, 2010). Em tal instituição, o homem tem o papel de cidadão atuante nos processos sociais, onde a sociedade é o berço que abriga o cidadão em que o mesmo entra em contato com o outro.

A instituição analisada conta com aproximadamente quinhentos e setenta alunos, distribuídos em dois turnos, atendendo de trinta a quarenta e cinco alunos por sala. Possui vinte e cinco professores, eventuais e efetivos - além de dois recreadores, para atividades lúdicas e supervisão, e cinco monitores de dança, música, artesanato, informática e para assistência na biblioteca -, sendo que a formação de dezoito dentre os profissionais docentes equivale exclusivamente à Licenciatura em Pedagogia, variando os demais entre as Licenciaturas de Língua Portuguesa, Educação Física, Artes e Matemática, somadas à Pedagogia.

Constatou-se em campo que o bairro do Ipiranguinha, onde a escola se localiza, é populoso e distante do centro da cidade em quatro quilômetros, sendo visto pela população de Ubatuba como um bairro violento, de certo modo isolado. Neste bairro existe um Pronto Socorro, consultórios odontológicos, supermercados, padarias, lanchonetes, açougues, bicicletarias etc. Possui também diversas igrejas evangélicas e uma católica, não contando com espaço de lazer (apenas a quadra da escola em questão).

Descrevendo-se a estrutura da Escola Municipal Mário Covas, cabe destacar que possui uma Secretaria - um espaço com duas salas, que inclui a Diretoria -, uma sala de recursos, uma sala dos professores, uma enfermaria, uma quadra poliesportiva (com possibilidades de se tornar coberta em 2011), almoxarifado, laboratório de informática - com doze computadores, vinte e quatro cadeiras de escritório e quatro mesas de estudo, além do monitor, formado no SENAI, que estabelece um elo entre esta instituição e a E. M. Mário Covas -, pátio coberto, estacionamento próprio, refeitório, cozinha, biblioteca - que é usada como sala da Coordenação Pedagógica e, em 2009, era utilizada como sala de reforços -, quatro banheiros e doze salas de aula. Contando com espaços específicos e bem explorados, a instituição de estudo de caso demonstra diferenciais para com outras escolas municipais, ou mesmo estaduais.

De acordo com o Projeto Político Pedagógico e com as observações realizadas pelo pesquisador neste estudo de caso, há outras iniciativas que diferenciam a E. M. Mário Covas da maioria das escolas de Ubatuba: atividades promovidas pelos monitores podem ser consideradas como um início de realizações voltadas à virtualidade dos alunos. Para com estes profissionais haveria de se ter uma atenção especial, por parte dos docentes e da gestão, pois também constituem um primeiro passo para colaborar com as mudanças da instituição, a caminho de adotar as ideologias da Escola da Ponte. 
Atividades extraclasses são organizadas pelos aqueles monitores, especificamente as monitoras de dança - que elabora com as alunas coreografias acompanhadas por ritmos como MPB, rock e jazz -, e de música - que trabalha com os alunos teoria e prática de instrumentos musicais como violão, teclado e violino -, bem como exposições organizadas pela monitora de artesanato e a professora de Educação Artística, com produções das aulas de arte, abertas aos alunos, pais e à comunidade. Estas exposições, somadas à apresentações de dança e música, são atrações em comemorações específicas da instituição deste estudo de caso, como Dia das Mães, dos Pais, do Folclore, das Crianças e no encerramento do ano letivo, em que o fim das aulas, o Natal e o Ano Novo são celebrados em conjunto.

As informações sobre estas atividades extracurriculares, inseridas como complemento lúdico e criativo em relação às demais disciplinas do currículo da escola, foram colhidas por meio das observações do pesquisador neste estudo de caso, e também pôde-se constatar que, além destas realizações específicas, cotidianamente os outros professores buscam trabalhar com atividades lúdicas e dinâmicas, em meio às aulas expositivas, com a exibição de filmes, momentos de leitura, desenho livre e jogos pedagógicos, além da contação de histórias.

Diante deste panorama voltado à utilização educacional constante das novas tecnologias, constatou-se a existência de um local apropriado para a realização de um estudo de caso, de acordo com todas as discussões propostas ao longo desta pesquisa. Para que se pudesse constatar qual a ideia que os docentes da instituição em questão faziam do que é o virtual, e se a concepção destes profissionais valorizava não apenas as novas tecnologias, como também o estímulo à criatividade e à imaginação foi, portanto, questionada e analisada a concepção que os professores da instituição possuíam para com a virtualidade, e se para eles lidar com o virtual se resumia à utilização das tecnologias digitais.

Na medida em que a questão que orientou esta pesquisa foi analisar as manifestações do virtual, tanto na mente humana como nas novas tecnologias, e constatar as concepções que o profissional docente possui para com a virtualidade na aprendizagem, procurou-se compreender o ponto de vista dos professores da instituição deste estudo de caso, se eles reconhecem a importância do estímulo da criatividade e imaginação de seus alunos e se desenvolvem atividades condizentes com tais capacidades, incluindo as que se utilizam das novas tecnologias para sua execução total ou parcial.

Para tais averiguações foi utilizado, além das observações em campo, das consultas a documentos da escola e da Secretaria Municipal de Educação, um questionário com questões abertas (vide Apêndice C), com perguntas voltadas a estas dúvidas sobre o desenvolvimento da 
virtualidade, de forma integral e efetiva. A coleta de dados, realizada pelo questionário qualitativo com os professores da E. M. Governador Mário Covas Júnior, demonstrou que as concepções sobre a virtualidade estão restritas ao que pode ser verificado no ambiente virtual, sem que seja considerada a capacidade mental, inerente ao ser humano, de criar e imaginar.

\subsection{Apresentação e Análise do Questionário de Dados Quantitativos}

Como instrumento de coleta de dados complementar às observações do pesquisador deste estudo de caso, foi realizado um questionário de dados quantitativos, realizado como uma sondagem, sobre o uso das novas tecnologias pelos profissionais docentes da instituição de caso desta pesquisa. As perguntas direcionadas para tal verificação foram:

- Você utiliza as novas tecnologias em seu cotidiano?

- Você possui conhecimentos básicos em informática?

- Cite três programas (softwares) que você utiliza em seu cotidiano pessoal e profissional, inclusive no preparo de suas aulas;

- Cite três programas (softwares) utilizados em suas aulas, que são preferidos por seus alunos também no uso diário do computador.

As duas primeiras perguntas solicitavam apenas que o professor dissesse que sim ou não, em relação ao uso das novas tecnologias em seu cotidiano, no que se refere aos momentos em que não estaria lecionando (ou em que se prepara para suas aulas), ou ainda se possuía conhecimentos básicos em informática. Depois, o docente era questionado sobre três programas computacionais (softwares) que ele costumava usar em seu cotidiano, tanto em momentos de aula como nos de não-trabalho.

Da mesma forma, era perguntado ao professor, dentre três dos programas utilizados em suas aulas, quais deles eram também usados por seus alunos em momentos extraclasse. A resposta para estas duas últimas questões limitava-se a três nomes específicos da área de softwares, que poderiam ser os mesmos ou variarem de uma questão a outra.

Em relação à primeira pergunta, vinte e três professores responderam sim quando questionados sobre o uso das novas tecnologias no cotidiano. Neste ponto, duas ressalvas devem feitas: a primeira é que os dois professores, que disseram não utilizar as novas tecnologias no cotidiano, podem muito bem terem considerado o fato de empregarem-nas apenas com fins 
voltados ao trabalho (elaboração de planos de aula, de avaliações, pesquisas de conteúdos), ou seja, o uso que fazem não é algo de todo dia; ou ainda, consideraram possuir pouco ou nenhum conhecimento sobre como lidar com computadores, ou outros recursos digitais, e optaram por dizer que não usam as novas tecnologias no cotidiano.

A segunda ressalva sobre a primeira pergunta se refere aos outros vinte e três profissionais docentes: o fato deles escolherem afirmar o uso cotidiano das novas tecnologias não os coloca como exploradores em potencial da virtualidade. Isto porque, muitas vezes, os indivíduos da sociedade de informação consideram usar o computador, dentre os muitos recursos digitais, apenas por saber ligá-lo, desligá-lo e operá-lo em suas funções básicas, de forma rápida, dinâmica e, por este motivo, desavisada (NICOLA, 2004).

Portanto, mesmo os que declararam utilizar as novas tecnologias, por mais que fique subentendido que o domínio das mesmas é inerente a esta declaração, há estes elementos que devem ser considerados na análise das respostas obtidas. Por fim, deve-se colocar que tal rapidez no uso dos recursos tecnológicos, atrapalham o devido processo de apreensão e análise crítica, comentada anteriormente nesta pesquisa, e que é considerado vital para o desenvolvimento da virtualidade do indivíduo.

Para com a segunda pergunta, obteve-se o mesmo número de professores para as respostas afirmativas e negativas, e pode-se afirmar que a causa de tal resultado seja a mesma observada na questão anterior. Os mesmos vinte e três profissionais acreditam possuir, pelo menos, os conhecimentos básicos para se operar um computador, já que por utilizarem-no cotidianamente - e, de maneira lógica, há de se pensar a partir desta constatação que tenham até mesmo o domínio deste recurso - sendo esta resposta, de certo modo, pré-determinada pela primeira pergunta.

Novamente, os mesmos dois professores que disseram não utilizar as novas tecnologias em seus cotidianos, admitem não possuir conhecimentos básicos em informática, e mais uma vez duas situações se apresentam: uma, que acaba por comprovar que estes dois professores não utilizam as novas tecnologias no cotidiano, por não possuírem conhecimentos básicos em informática.

A outra, que estes professores tenham considerados como "conhecimentos básicos" noções voltadas a todos os elementos que se referem às tecnologias de informação e comunicação, incluindo saberes técnicos como manutenção e reconhecimento de aparelhos, periféricos e acessórios (LÉVY, 1993). 
As outras duas perguntas desta sondagem podem ser consideradas de dados quantitativos, por limitarem o número de respostas válidas, correspondentes aos três softwares indicados por cada professor, dentre os que são utilizados por eles em suas aulas, e aos três softwares que cada um indicou e acredita serem usados por seus alunos fora da sala de aula, nos momentos de lazer do cotidiano deles.

Pode-se considerar que a comparação feita entre os programas de computador apontados pelos professores dentre os utilizados nas aulas e os que seus alunos utilizam fora dela demonstram um contraste, de certa forma já esperado, e que aponta a falta de sintonia entre os programas usados nas aulas e os que são preferidos pelos alunos: enquanto os docentes apontam softwares com caráter essencialmente pedagógico, por outro lado eles acreditam que seus educandos têm preferência por aqueles que oferecem entretenimento, incluindo jogos eletrônicos, e informações específicas.

Tabela - Respostas e porcentagens referentes às questões três e quatro

\begin{tabular}{|c|c|c|c|}
\hline $\begin{array}{c}\text { Programas utilizados } \\
\text { pelos professores }\end{array}$ & $\begin{array}{c}\text { Porcentagens } \\
\text { referentes }\end{array}$ & $\begin{array}{c}\text { Programas } \\
\text { preferidos pelos } \\
\text { alunos }\end{array}$ & $\begin{array}{c}\text { Porcentagens } \\
\text { referentes }\end{array}$ \\
\hline Microsoft Office Word & $80 \%$ & $\begin{array}{c}\text { Counter Strike / } \\
\text { Ragnarök }\end{array}$ & $92 \%$ \\
\hline Microsoft Power Point & $64 \%$ & $\begin{array}{c}\text { Windows Live } \\
\text { Messenger / Microsoft } \\
\text { Service Network } \\
\text { (MSN) }\end{array}$ & $80 \%$ \\
\hline Windows Movie Maker & $16 \%$ & Half Life & $80 \%$ \\
\hline Windows Media Player & $32 \%$ & Quicktime Player & $16 \%$ \\
\hline Google Maps & $8 \%$ & iTunes & $32 \%$ \\
\hline Google Earth & $8 \%$ & Ares & $16 \%$ \\
\hline
\end{tabular}




\begin{tabular}{|c|c|c|c|}
\hline Adobe Flash Player & $40 \%$ & E-mule & $32 \%$ \\
\hline Letroca & $16 \%$ & Limewire & $8 \%$ \\
\hline
\end{tabular}

Há algumas considerações a serem feitas diante das respostas acima: em relação aos programas utilizados pelos professores, pôde-se perceber uma tendência maior quanto ao uso de produções de texto e apresentações para com as aulas, devido à porcentagem relativa ao Word e ao Power Point. Cabe apresentar aqui também que, dentre os $80 \%$ que utilizam o processador de textos da Microsoft, $90 \%$ trabalham com o ensino de Língua Portuguesa, do $1 .^{\circ}$ ao $5 .^{\circ}$ ano. Neste contexto, incluem-se os $16 \%$ que promovem partidas com o jogo eletrônico Letroca, que promove a formação de palavras - das mono às polissilábicas - a partir de seis letras préselecionadas pelo próprio computador.

Portanto, a relação do uso do software com a disciplina vinculada à atividade realizada em questão é notável, o que pode ser comprovado também com o uso dos mapas e imagens via satélite, respectivamente apresentados pelos programas Google Maps e Google Earth, para o ensino de Geografia. Por outro lado, os softwares considerados pelos professores como preferidos por seus alunos se enquadram na categoria do entretenimento eletrônico - como Counter Strike, Ragnarök e Half Life, jogos eletrônicos de enorme sucesso, tendo como plataforma de execução os computadores pessoais -, e/ou não se relacionam com a proposta destes profissionais para suas aulas, e quando possuem alguma relação, são totalmente diferentes em suas funções (a exemplo do Windows Media Player, aplicado pelos professores, e do iTunes, utilizado pelos alunos, segundo o corpo docente).

O caso neste ponto não é considerar a discrepância entre os programas utilizados pedagogicamente e aqueles que são realmente empregados pelos alunos em seu cotidiano. A questão mais relevante é que os profissionais docentes deste estudo de caso admitiram que os softwares considerados pedagógicos não correspondem às expectativas dos alunos, o que vem a ser satisfeito com os aplicativos citados na última questão da sondagem. Esta discrepância mostra a possibilidade de exploração da virtualidade que, se o professor demonstrar atenção, pode vir a ser desenvolvida como capacidade humana para o aprendizado, da devida maneira.

Tal levantamento inicial de dados ofereceu ao pesquisador desta dissertação a oportunidade de aprofundar a compreensão da concepção de virtualidade e do uso das novas tecnologias por parte do profissional docente da instituição deste estudo de caso. Com base 
nestes elementos, foi realizado um questionário de questões abertas, cuja análise é relatada no item a seguir.

\subsection{Apresentação e Análise do Questionário de Questões Abertas}

A principal função do questionário, enquanto instrumento de coleta de dados, foi colher as opiniões sobre o cotidiano dos professores, bem como as concepções que os mesmos possuíam para com a noção de virtualidade e sua aplicação nas realizações educacionais. Foram elaboradas cinco questões, cujos enunciados procuravam auxiliar o foco da resposta do professor, bem como direcioná-lo sobre responder sobre possuir uma noção conceitual - ou não - do que vem a ser a virtualidade enquanto capacidade humana. As cinco questões eram:

$>$ A constante evolução e inovação das novas tecnologias propõem não apenas uma nova maneira de lidar com o saber, mas também de administrá-lo em um contexto diferenciado: o virtual. E para você, o virtual no desenvolvimento intelectual e cultural está restrito apenas ao uso das novas tecnologias, como computadores, a Internet, videogames, celulares e outros recursos digitais?

A Aristóteles, em suas concepções filosóficas, diz que o virtual é uma característica mental e psicológica do ser humano, chamada virtualidade, pela qual ele planeja suas ações e idealiza o seu potencial para o futuro. Em sua opinião, é possível a existência do virtual independentemente das novas tecnologias?

> Para alguns autores, o ambiente virtual das novas tecnologias é uma extensão da imaginação humana, tornando visível o que é elaborado há tempos pela mente. Diante desta afirmação, comente o uso para com as novas tecnologias em relação a sua disciplina, assim como o que você acha do virtual e de que modo ele influencia os alunos em diferentes aspectos (social, cultural e /ou pedagógico).

$>$ Você considera o virtual como um recurso para potencializar a interdisciplinaridade, nas atividades que envolvem o uso dos computadores? E fora do ambiente escolar, você sabe e/ou reconhece algo em relação a uma melhor compreensão e utilização das novas tecnologias por parte dos alunos, a partir do que aprendem na escola?

Em relação à virtualidade, tal qual a oportunidade de projetar e potencializar ações e atitudes, considere o modo como planeja suas aulas: como você relaciona este planejamento com as duas concepções de virtual (filosófica e tecnológica)? Em um 
momento anterior, ao imaginar as realizações em sala, como as ações são projetadas para com a(s) classe(s), em relação aos alunos, aos conteúdos e recursos didáticos?

Para análise das respostas, foi considerada desde a explicação dada pelo pesquisador aos docentes participantes - sobre a ideia do virtual e suas manifestações na mente humana e nas novas tecnologias, que consistiu em uma breve exposição das ideias de Aristóteles (1979) sobre homem virtuoso, como também as de Pierre Lévy (1993, 1996), sobre o virtual apresentado nas novas tecnologias -, às respostas dadas, uma a uma, por cada professor. O questionário foi distribuído entre os vinte e cinco professores, durante a realização de um HTPC (Hora de Trabalho Pedagógico Coletivo). A não ser pela explanação inicial, anterior à entrega dos questionários - para que os professores fossem orientados para com o sentido de alguns termos , junto da afirmação de que não havia resposta correta ou incorreta, e que considerassem exclusivamente o cotidiano profissional de cada um, não houve qualquer intervenção a mais por parte do pesquisador durante o procedimento. A coleta de dados, portanto, teve as respostas obtidas a partir das opiniões e concepções individuais, registradas por escrito pelos professores da instituição.

A primeira questão abordava se, para cada um dos professores, o virtual no desenvolvimento intelectual e cultural está restrito apenas ao uso das novas tecnologias, como computadores, a Internet, videogames, celulares e outros recursos digitais. A resposta de vinte dentre os profissionais docentes voltou-se para o fato de que, para eles, a noção de virtual se referia única e exclusivamente à utilização das tecnologias digitais, sendo que os outros cinco relataram possuir apenas uma noção superficial da relação entre o virtual e a imaginação.

Eis alguns relatos para confirmar o pensamento voltado a tais ideias, preservando a identidade dos sujeitos, dentre os vinte e cinco professores entrevistados, por não haver qualquer necessidade da divulgação de nomes, além de estar previsto no termo de consentimento livre e esclarecido, entregue junto do questionário e assinado por todos os docentes para que participassem desta coleta de dados (vide Apêndice B):

Sujeito 1 - "A ideia do virtual como um mundo imaginário, que pode se tornar real, é bem retratada em filmes como Matrix, em que a assimilação de informações é automática e tudo o que é assimilado pela mente pode se tornar real, inclusive experimentado pelos sentidos".

Sujeito 2 - "Se o virtual existe nas máquinas, e todas as tecnologias são desenvolvidas a partir das capacidades do ser humano, é bem capaz que o ambiente apresentado pelos computadores exista também na mente dos indivíduos". 
Sujeito 3 - "Acho que o virtual que se apresenta nas novas tecnologias não é encontrado em nenhum outro lugar. Por mais que o ser humano tenha sua virtualidade, ela não é elaborada da mesma forma, nem produz as mesmas coisas".

Desconsiderando os termos utilizados, existe algo bem interessante na afirmação do sujeito três: realmente a virtualidade humana não se assemelha à apresentada pelas novas tecnologias. Segundo Aristóteles (1979), enquanto a primeira é uma capacidade, uma virtude humana - estimulada pela criatividade, tendo a mediação simbólica como instrumento e a imaginação como "cenário" - a segunda apresenta este mesmo "cenário", antes contemplado por aquele que o utilizava mentalmente, de maneira que possa ser visualizado em escala global. Esta afirmação do docente reflete um ponto importantíssimo em relação à virtualidade: manifestandose a partir da mente humana, ela possibilita a criação; adaptada ao ambiente virtual, torna-se espelho do que a humanidade cria e transmite, gera e inova.

A segunda questão, baseada na proposição aristotélica, questionava os professores sobre a possibilidade de haver uma virtualidade independente da apresentada pelas novas tecnologias. A resposta desta questão se mostrou unânime, pois todos os professores que responderam a esta pergunta apontaram o fato que, para eles, a virtualidade era, antes, característica específica das mídias pertencentes às tecnologias digitais, restrita aos ambientes virtuais dos sites da Internet, ou ainda aos cenários muito elaborados, graças à evolução da computação gráfica, dos jogos eletrônicos atuais.

Com base nas ideias de Aristóteles, expostas na explicação inicial do pesquisador, anterior ao preenchimento do questionário pelos professores deste estudo de caso, poderiam afirmar que a virtualidade se faz presente na capacidade humana de projetar significados, pensamentos e ações, para realizações presentes ou futuras, independentemente dos recursos disponibilizados pelas novas tecnologias.

Com isto, percebeu-se que os profissionais docentes da instituição deste estudo de caso assumiam apenas a importância do virtual nas novas tecnologias nas realizações pedagógicas, como única forma de estímulo da virtualidade - ainda que ineficaz, considerando-se os dados obtidos com a sondagem, anteriormente analisada. A oportunidade do pesquisador ter explanado as questões pertinentes à compreensão básica da virtualidade enquanto capacidade mental humana, neste caso, foi fundamental, para a troca de ideias e a mobilização docente em torno de uma reflexão inédita, envolvendo inclusive as próprias práticas ao longo de vários anos letivos. Duas sentenças dos professores nesta questão reforçam esta afirmação: 
Sujeito 2 - "Ao considerar a criatividade humana como elemento da virtualidade e esta, por sua vez, como uma capacidade fundamental tanto para a aquisição e subjetivação da linguagem, como em relação ao uso das novas tecnologias, o professor tem a oportunidade de aplicar em suas aulas atividades que possam conjugar o desenvolvimento humano e sua ampliação, voltados para o saber discente".

Sujeito 4 - "Não poderia ter concebido antes que o virtual esteve sempre com o ser humano, como um 'lugar' em que age nossa imaginação. Achava que era simplesmente um ambiente visível pela tela do computador, mas me parece bem provável agora que tenhamos tal capacidade em nossas mentes".

A terceira questão, que abordava a ideia do virtual enquanto extensão da imaginação humana, perguntava ao professor o uso que ele procura fazer das novas tecnologias em suas aulas, e o seu pensamento para com as influências do virtual na sociedade e, consequentemente, em seus educandos. A maioria dentre os vinte e cinco profissionais docentes entrevistados dezoito deles - assumiu que, apesar dos recursos tecnológicos disponibilizados pela instituição, utilizam as novas tecnologias ocasionalmente, para uma consulta direcionada.

Os outros sete afirmaram utilizar com mais frequência; mas, ainda assim, quando em contato com o laboratório de informática, relataram passar atividades restritas à pesquisa em sites, sem que haja a devida orientação quanto aos conteúdos, bem como recorrer a jogos eletrônicos e programas específicos para realizações específicas, ou como complemento das atividades de sala de aula. Eis uma sentença, de um destes sete professores, sobre o uso do computador em suas aulas:

Sujeito 5 - “Apesar do laboratório da escola ser bem equipado e contar com um monitor qualificado pelo SENAI, confesso não utilizá-lo como deveria ou gostaria. O uso dos alunos não vai além de pesquisas complementares aos assuntos das aulas, ou mesmo a produção de textos e partidas em dupla com jogos eletrônicos pedagógicos”.

Sujeito 8 - "Talvez a questão seja repensar a ideia que as novas tecnologias assumem na atuação docente, não como ferramentas, mas como suporte para divulgar o que a criação humana permite, e neste processo se faz presente o virtual".

Todos os professores destacaram as mudanças socioculturais referentes às novas tecnologias, responsáveis pelas mudanças no uso para com o computador, no que diz respeito à interatividade e os recursos que se encontram disponíveis nesta tecnologia. Verificaram que o modo como os alunos apreendem, assimilam e analisam informações mudou graças a tal interação com os computadores, que também por meio dos ambientes elaborados no virtual 
tecnológico, divulgam dados em grandes quantidades, em uma grande capacidade e velocidade de armazenamento. Diante destas mudanças, os professores admitiram possuir preocupações para com a atuação docente e formas inovadoras de transmitir conteúdos, e as sentenças a seguir confirmam tais colocações:

Sujeito 6 - “(...) As mudanças promovidas pelas novas tecnologias realmente mudaram a forma como os alunos usam os computadores, inclusive devido à Internet, que promove informações, jogos e até informações pessoais, em sites de relacionamento".

Sujeito 7 - "Os professores têm hoje a possibilidade de trabalhar com os computadores como transmissores de conhecimento, que por sua vez deve ser discutido em sala para que ganhe valor no cotidiano dos alunos, evitando que eles venham a alimentar um desinteresse para com as aulas (...)".

Estas sentenças, de forma específica, se complementam em relação à questão três, já que uma apresenta o modo como os alunos se utilizam das novas tecnologias, enquanto mudança no comportamento humano em geral, e a segunda coloca a importância do professor em meio à apreensão de informações, para com a devida análise crítica, sem que os educandos percam o interesse ou o foco do processo de aprendizagem.

A quarta questão, por sua vez, em uma abertura permitida para com a interpretação dos professores - devido ao uso do termo virtual sem qualquer menção ao ser humano ou às novas tecnologias -, obteve respostas interessantes, que respeitaram as duas concepções de virtualidade. Dentre os vinte e cinco profissionais docentes, vinte e um optaram por falar do uso do virtual presente nas novas tecnologias, voltadas para a interdisciplinaridade, destacando o uso de softwares específicos e/ou jogos eletrônicos que trabalhem, de modo sintetizado, a interdisciplinaridade por meio do domínio da linguagem e da assimilação de conteúdos matemáticos, históricos, geográficos e/ou científicos:

Sujeito 8 - "Acredito que a escolha certa dos programas de computador seja uma maneira de complementar o ensino de conteúdos específicos dos primeiros anos do Ensino Fundamental, cabendo aos professores priorizar aqueles que desenvolvam a linguagem, noções de número e cálculo, bem como conceitos cabíveis às demais ciências".

Os outros quatro professores destacaram, de forma inovadora - de acordo, inclusive, com a proposta da explanação inicial do pesquisador - a importância de se desenvolver a capacidade criativa para lidar com as novas tecnologias como ferramentas, e não como guias contemporâneos da formação do indivíduo. Apontaram que as novas tecnologias exercem influência tanto positiva quanto negativa, por meio das informações que propaga, cabendo ao 
professor a responsabilidade de orientar a análise crítica dos conteúdos, bem como de procurar modos inovadores de desenvolver as aulas de suas disciplinas, conjugando as discussões em sala com o uso devido do computador, fomentando no aluno uma natureza interdisciplinar e pesquisadora, mesmo que inicial:

Sujeito 9 - "A orientação docente pode auxiliar o aluno a obter o olhar crítico necessário para analisar as informações obtidas com o computador, realizando a relação necessária entre os conteúdos para que a aprendizagem torne-se dinâmica e eficaz".

Sujeito 10 - "Se a virtualidade pode ser desenvolvida a partir da mente humana, com o professor orientando o modo como as informações são apreendidas e analisadas, logo o ensino pode ser feito eficaz e inovador para o aluno, complementando-o com conteúdos interdisciplinares, voltados para a inovação na atuação docente e no saber discente".

Quanto à última questão, com foco exclusivo no ponto de vista docente sobre a virtualidade, enquanto capacidade de se projetar futuramente em relação a pensamentos e ações, guiados pelos significados proporcionados pela linguagem, perguntou-se como o virtual influencia as aulas, nas concepções filosófica e tecnológica. Também indagou se o professor considera a em potência os seus atos e palavras, diante do equilíbrio entre o planejamento e a realização da aula em si. Vinte e dois professores, ao responderem tal questão, disseram que o virtual das novas tecnologias é considerado de forma mais constante pelos profissionais docentes em sua atuação, esquecendo-se de valorizar o desenvolvimento de atividades que sejam voltadas à criatividade e imaginação:

Sujeito 11 - "A virtualidade apresentada como uma capacidade humana não é uma concepção muito difundida, ficando o senso comum voltado para as novas tecnologias. O virtual passa a ser considerado como elemento pertencente apenas a estes recursos, e assim a tecnologia passa a ocupar o grau de importância do desenvolvimento humano”.

O uso das capacidades de criar e imaginar acaba restrito a uma ou outra tarefa que exige da capacidade artística dos educandos. O mesmo número de professores questionados disse não considerar a virtualidade como recurso de planejamento das aulas, voltando o foco para o que está programado para se lecionar naquele momento especificamente, incluindo o que será dito e em que momento. No entanto, ao invés do discurso docente ser planejado sobre aspectos complementares, ou mesmo improvisado, estes vinte e dois professores concordam que a virtualidade se apresenta como um panorama, para que ocorra o desenrolar de conceitos préformulados pela sociedade ou pelo âmbito acadêmico. 
Uma minoria, dentre três professores, disse considerar a mentalização do que podem falar e fazer, principalmente quando se perguntam sobre modos diferenciados de passar um determinado conteúdo para os educandos. Portanto, consideram a virtualidade como instrumento para ir além do que planejaram, recorrendo ao mesmo como uma espécie de intuição, para fortalecer a apreensão e participação de seus alunos nas aulas:

Sujeito 9 - "O ambiente virtual é um espaço de interação e da possibilidade de enxergar o que um indivíduo pode criar. Mas sem o devido estímulo, a mente humana não desenvolve sua virtualidade, o que compromete seu uso a partir das tecnologias".

Sujeito 12 - "Pensar na virtualidade como a capacidade de projetar na mente o que pode vir a ser real é algo realmente interessante, principalmente quando focamos na linguagem a ser utilizada e nos conteúdos a serem ministrados. Portanto, o professor pode encontrar nesse procedimento mais um recurso a favor de sua atuação, modificando palavras e atitudes de acordo com o contexto diário de sua sala”.

Os relatos obtidos como dados da pesquisa e apresentados de maneira sintetizada, além de servirem para relembrar e reforçar concepções teóricas desta dissertação, voltadas à virtualidade, também demonstraram como o profissional docente desenvolve o seu trabalho na instituição deste estudo de caso. O virtual na atuação docente foi analisado como elemento reconhecido, mas não aplicado, se for considerada - a partir destas respostas e das sentenças que as exemplificam - a ausência de criatividade e de improviso, envolvendo ações mentais relativas à fala e à atitude do professor neste estudo de caso, durante as aulas e em momentos anteriores.

A virtualidade docente não reside apenas no desenvolvimento de temas específicos, somados a recursos diversificados, para que suas aulas estejam previamente planejadas. Afinal, o professor deve se preocupar com também com a virtualidade discente, que pode não ser devidamente estimulada pelos conteúdos previamente estipulados, e direcionar as discussões para outra (s) direção (ões). Neste momento, há a possibilidade de que este profissional estimule o educando em sua habilidade para com o virtual, apresentando elementos em sala de aula que, mesmo oriundos do imprevisto, podem vir a concretizar o ensejo educacional da autonomia e da análise crítica em relação às informações apreendidas cotidianamente.

Diante desta análise das questões qualitativas, relacionando-as com os dados analisados a partir das observações em campo e da sondagem, há de se considerar, de certo modo, promissora a possibilidade do estímulo à virtualidade discente na Escola Municipal Mário Covas. Este apontamento considera não apenas a parceria de ideias e ações em relação à Escola da Ponte, mas também por uma minoria docente reconhecer as potencialidades que a virtualidade, 
enquanto capacidade humana, permite alcançar. Contudo, também há de se refletir diante dos demais, que subestimam a própria capacidade de criação e desenvolvimento e, consequentemente, o fazem com seus alunos, ao seguirem concepções prévias para com a própria capacidade de criar e renovar.

Diante destas constatações, ao se avaliar, portanto, o modo como a virtualidade se faz presente na mediação simbólica e linguagem discente da instituição de estudo de caso, verificase que, na aprendizagem, ainda utiliza-se a virtualidade como um tipo de acessório. Atitude, infelizmente, ainda muito praticada, em muitos momentos pedagógicos, nos quais o professor apenas se apoia em recursos audiovisuais e/ou tecnológicos, a fim de disfarçar conteúdos que não estimulam seus alunos, mesmo com o devido planejamento. Neste instante, o professor tem a possibilidade e capacidade de promover novas discussões e interações, em função do apreender e analisar o real, por meio do devido estímulo ao virtual. 


\section{CONSIDERAÇÕES FINAIS}

Em meio aos apontamentos conclusivos (mas de forma alguma definitivos) que serão apresentados, cabe colocar novamente que o objeto de pesquisa foi a virtualidade em suas duas manifestações. Dentre os objetivos, a pesquisa almejou analisar a concepção contemporânea sobre o virtual, principalmente do ponto de vista docente, verificando se este se mantém restrito ao ambiente virtual das novas tecnologias; pesquisar sobre as duas formas pelas quais o virtual se faz presente nas realizações humanas - seja por manifestações exclusivamente mentais, a criatividade e a imaginação, ou mesmo pela extensão das mesmas, proporcionada pela realidade virtual -; e ainda analisar, por meio do estudo de caso feito com a Escola Municipal Governador Mário Covas Júnior, como se efetivam as ideias que o professor possui para com as manifestações do virtual, e como as mesmas poderiam ser devidamente trabalhadas para com seus alunos.

A tentativa de verificar as duas vertentes do virtual - a inerente às capacidades mentais do homem e a que se manifesta por meio das tecnologias digitais - se constituiu na hipótese deste trabalho. A hipótese foi baseada na premissa de que, o professor deve reconhecer em seus alunos a importância do virtual não apenas com a utilização das novas tecnologias, mas também por meio das capacidades mentais de criação e imaginação. Assim, o docente seria capaz de desenvolver em seus alunos a verdadeira concepção de virtualidade.

Em relação a este cenário, surgiu uma problematização para com o modo pelo qual os professores buscam estimular as capacidades de seus educandos: em meio a tantos recursos tecnológicos, a educação ainda é desenvolvida de forma padronizada, sem a devida exploração da criatividade e do autoaprendizado, acompanhado de um raciocínio crítico. O questionamento advindo da problematização desta realidade foi: é possível modificar o ponto de vista docente sobre como a verdadeira virtualidade pode ser desenvolvida, como forma de complementação da mente humana para com as novas tecnologias? Com tal questão, busca-se focar o problema pesquisado na falta de se utilizar um aprendizado multimídia, no qual o virtual enquanto capacidade humana corresponda à virtualização da realidade nas novas tecnologias, e vice-versa.

O objeto desta pesquisa foi analisado, à medida que as vertentes humana e tecnológica em relação à virtualidade foram apresentadas e discutidas ao longo de toda a abordagem teórica desta dissertação. Os objetivos foram alcançados, tanto os teóricos como o objetivo prático de realizar um estudo de caso na E. M. Mário Covas, por meio do qual foram coletados dados, em 
observações e questionários com questões quantitativas e qualitativas. Os objetivos, por sua vez, conduziram à confirmação da hipótese, de que é possível o professor reconhecer o virtual enquanto manifestação da mente humana, mesmo que em sua prática docente ainda não consiga reconhecer modos de tornar isto possível.

A problematização, portanto, conduz a uma resolução parcial da pesquisa como um todo, pois ao mesmo tempo em que se verificou a possibilidade de valorização docente em relação à virtualidade - e dentre as próprias realizações, as de caráter lúdico e criativo, assim como a parceria realizada com a Escola da Ponte -, outra constatação é a de que um trabalho mais constante e duradouro seria necessário, para que as concepções apreendidas na rápida explanação do pesquisador pudessem ser aprofundadas, como também as ações dos professores pudessem se nortear pela ideia de estimular a virtualidade de seus educandos. Assunto que possa ser explorado em profundidade por outros pesquisadores, em outras instituições ou ainda, quiçá se torne objeto de pesquisa voltado a uma futura tese do autor desta dissertação.

Diante de todas as realizações da pesquisa em questão, surge a possibilidade de que as propostas feitas em relação à virtualidade, voltadas ao corpo docente da instituição de estudo de caso, venham a ser concretizadas. O questionamento direcionado ao uso das novas tecnologias, bem como a apresentação de conceitos iniciais sobre o virtual aos professores foi uma das realizações que conduziram às discussões e constatações obtidas, para que o ponto de vista docente fosse analisado e, inclusive despertado, pelo menos em alguns aspectos, para com o desenvolvimento e valorização da criatividade e imaginação de seus educandos. Pode parecer o final de um processo apenas, mas com tal perspectiva de continuidade na escola de estudo de caso, por meio das atividades propostas a partir da parceria com as ideias e pensamentos vindos da Escola da Ponte, esta pesquisa mostrou possuir características mais coerentes à uma proposta de um início, com a implantação de um novo elemento no modo de pensar dos professores da $\mathrm{E}$. M. Governador Mário Covas Júnior.

A coleta de dados demonstrou a todo o momento a visão unilateral docente para com a virtualidade, identificando-a inicialmente como manifestação exclusiva das novas tecnologias. A intervenção sutil do pesquisador, por meio de uma explanação inicial e anterior à aplicação do questionário de questões abertas, trouxe questionamentos e surpresas para com a ideia da virtualidade enquanto capacidade mental humana, de modo que foi fundamental implantar novas concepções, a partir das dúvidas que ficaram pendentes sobre as discussões acerca do que é o virtual. A descoberta docente da existência de uma capacidade virtual inerente à própria formação do ser humano foi fundamental, inclusive se considerarmos a adoção da instituição por 
parte das ideologias da Ponte. Somente deste modo poderão ser apresentadas futuramente propostas específicas, que por meio de vários modos de trabalhar a virtualidade dos alunos, desenvolverá a tendência da escola de integrá-los em um contexto interdisciplinar.

A contribuição desta pesquisa para com o autor da dissertação diz respeito tanto às concepções teóricas quanto às realizações práticas, em uma evolução de sua práxis enquanto pesquisador e aluno do nível de Mestrado. O autor assume, inclusive, não possuir o conhecimento da vertente humana para com o virtual antes de iniciar as leituras e análises que o conduziram à elaboração deste trabalho, sendo este uma realização que contribuiu principalmente para com a modificação de suas próprias ideias. Eis, portanto, a principal motivação para a concretização desta pesquisa: para que outros profissionais docentes pudessem reconhecer outras concepções voltadas ao desenvolvimento do indivíduo, ainda mais por serem os responsáveis para que tal processo seja efetivado.

Por fim, cabe destacar a necessidade de um aprofundamento em relação aos elementos encontrados na instituição de estudo de caso, no que diz respeito ao ponto de vista docente, assim como uma análise detalhada, voltada para os educandos em questão, verificando suas opiniões em relação às atividades lúdicas e criativas, desenvolvidas pela escola. Uma ideia válida é a de que, após o ano de 2011 - com um ano letivo ou mais da adoção e aplicação das ideologias da Escola da Ponte, por parte da escola de estudo de caso -, possa vir a serem avaliadas as contribuições dos ideais da escola portuguesa, principalmente em relação à virtualidade, sendo novamente consideradas as expectativas e opiniões dos professores e incluindo, por sua vez, as dos alunos - questões consideradas pelo autor da pesquisa para realizações futuras, dentre artigos, palestras e, principalmente, um Doutorado na área de Educação. 


\section{REFERÊNCIAS BIBLIOGRÁFICAS}

ALVES, R. Filosofia da Ciência: introdução ao jogo e suas regras. 17. ed. São Paulo: Brasiliense, 1993.

ALARCÃO, I. Professores Reflexivos em uma Escola Reflexiva. São Paulo: Cortez, 2003.

APRENDER Virtual. Ansiedade de informação. Disponível em <http://www.aprendervirtual.com/ver_noticia.php?codigo=81> Acesso em 05 set. 2009.

ARISTÓTEleS. Poética / Organon / Política / A Construção de Atenas. Col. Os Pensadores. v. 3. São Paulo: Nova Cultural, 1979.

ASCOTT, R. O que é Virtual? Paulo Neves (trad.) São Paulo: Ed. 34, 1999.

ASSIS, J. de P. Artes do Videogame: conceitos e técnicas. São Paulo: Alameda, 2007.

ASSOCIAÇÃO Brasileira de Educação à Distância. Disponível em <http://www.abed.gov.br> Acesso em 14 ago. 2009.

BELTRÃO, L. Teoria geral da comunicação. Brasília: Thesaurus, 1977.

BRASIL. Lei 9.394 de 20 de dezembro de 1996. Lei de Diretrizes e Bases - LDB.

CAMPBELL, J. O Poder do Mito. São Paulo: Palas Athena, 2004.

CASTELlS, M. A Galáxia da Internet. Maria Luiza Borges (trad.). Rio de Janeiro: Jorge Zahar, 2003.

CHARTIER, R. A Aventura do Livro: do leitor ao navegador. São Paulo: UNESP, 2000. 
COSTA, R. da. A Cultura Digital. 2. ed. São Paulo: Publifolha, 2003.

CSIKSZENTMIHALYI, M. A Descoberta do Fluxo: a psicologia do envolvimento com a vida cotidiana. Rio de Janeiro: Rocco, 1999.

DEBORD, Guy. A Sociedade do Espetáculo. Disponível em < http://www.ebooksbrasil.org/eLibris/socespetaculo.html> Acesso em 10 jul. 2010.

DIAS, V. L. C.; SUMAN, R. B. Educação à Distância e Acesso ao Ensino Superior: reflexões $\begin{array}{llllll}\text { sobre a formação dos } & \text { professores. } & \text { Disponível } & \text { em }\end{array}$ $<$ http://aveb.univap.br/opencms/opencms/sites/ve2007neo/ptBR/chamada/Trabalhos_Aprovados_-_Resumos.html> Acesso em 30 set. 2009.

DOWBOR, L. Tecnologias do Conhecimento: os desafios da educação. Petrópolis, RJ: Vozes, 2001.

DUARTE, J.; BARROS, A. (org.). Métodos e Técnicas de Pesquisa em Comunicação. 2. ed. São Paulo: Atlas, 2006.

ELIADE, M. Imagens e Símbolos. São Paulo: Martins Fontes, 1991.

FREIRE, P. Pedagogia da Autonomia: saberes necessários à prática educativa. 25. ed. São Paulo: Paz e Terra, 2002.

GALISI, D. Realidade virtual. Acesso: revista de educação e informática. São Paulo: Secretaria de Estado da Educação, 2003, p. 35-38.

GOMES, E. da S. A Universidade do Futuro na Sociedade do Conhecimento: o ensino $\begin{array}{lllll}\text { superior à } & \text { distância } & \text { semipresencial. } & \text { Disponível }\end{array}$ $<$ http://aveb.univap.br/opencms/opencms/sites/ve2007neo/pt-

BR/chamada/Trabalhos_Aprovados_-_Resumos.html> Acesso em 30 set. 2009.

HUIZINGA, J. Homo ludens: o jogo como elemento da cultura. São Paulo: Perspectiva, 2000. 
JARDIM, J. M.; FONSECA, M. O. A informação como campo interdisciplinar. Disponível em <http://www.uff.br/neinfo/artigoinfo.html> Acesso em 13 dez. 2009.

JUNG, C. G. O Homem e Seus Símbolos. Rio de Janeiro: Nova Fronteira, 1998.

LEMOS, A. As estruturas antropológicas do cyberespaço. Disponível em <http://www.facom.ufba.br/pesq/cyber/lemos/estrcy1.html> Acesso em 04 jan. 2010.

. Cibercultura e mobilidade: a era da conexão. Disponível em <http://www.cem.itesm.mx/dacs/publicaciones/logos> Acesso em 06 out. 2009.

LÉVY, P. apud MASSAD, A. A caminho da inteligência coletiva. Disponível em <http://www.lainsignia.org/2002/noviembre/cyt_008.htm> Acesso em 21 dez. 2009.

LÉVY, P. As tecnologias da inteligência: o futuro do pensamento na era da informática. Carlos Irineu da Costa (trad.). Rio de Janeiro: Ed. 34, 1993.

O que é virtual? Carlos Irineu da Costa (trad.). Rio de Janeiro: Ed. 34, 1996.

Cibercultura. Carlos Irineu da Costa (trad.). Rio de Janeiro: Ed. 34, 1999.

MALINOWSKI, B. C. Argonautas do Pacífico Ocidental. Tradução Anton P. Carr. São Paulo: Abril Cultural, 1976.

MATTELART, A. \& M. História das teorias da comunicação. Luiz Paulo Rouanet (trad.). São Paulo: Loyola, 1999.

MCLUHAN, M. Os Meios de Comunicação como Extensões do Homem. 8. ed. São Paulo: Cultrix, 1996.

MENDES, C. L. Jogos Eletrônicos: diversão, poder e subjetivação. Campinas, SP: Papirus, 2006. 
MENEZES, A. do V. Esboço de uma ontologia do cyborg. Pre-texto. Disponível em <http://www.eco.ufrj.br/pretexto/sociais/soc2.htm> Acesso em 05 jan. 2010.

MINISTÉRIO da Educação. Legislação Referente à Educação a Distância. Disponível em <http://portal.mec.gov.br> Acesso em 21 jun. 2009.

Referenciais de Qualidade para a Educação Superior à

Distância. Disponível em <http://portal.mec.gov.br> Acesso em 21 jun. 2009.

MIRANDA, R. L. Além da Inteligência Emocional: uso integral das aptidões cerebrais no aprendizado, no trabalho e na vida. Rio de Janeiro: Campus, 1997.

MORIN, E. Cultura de Massas no Século XX. Maura Ribeiro Sardinha (trad.) Rio de Janeiro: Forense Universitária, 1997.

Os sete saberes necessários à educação do futuro. São Paulo: Cortez, 2001.

MÜLlER-GRANZOTTO, R. L. \& M. J. Fenomenologia e Gestalt-Terapia. São Paulo: Summus, 2007.

NICOLA, R. Cibersociedade: quem é você no mundo on-line? São Paulo: Senac, 2004.

. Cultura digital - Interface: Homem x Máquina. Col. Comunicação e Mídia. v. 1.

Bauru, SP: Departamento de Comunicação Social da FAAC/Unesp, 1999.

ORLANDI, E. P. Análise de Discurso: princípios e procedimentos. Campinas, SP: Pontes, 2005.

PIAGET, J. A Construção do Real na Criança. 3. ed. São Paulo: Ática, 2003.

SANTAELLA, L. Semiótica Aplicada. São Paulo: Pioneira, 2008.

SCHAFF, A. A sociedade informática: as conseqüências sociais da segunda revolução industrial. Carlos Eduardo Jordão (trad.). São Paulo: Brasiliense, 1993. 
SECRETARIA Municipal de Educação de Ubatuba. Projeto Político Pedagógico da Escola Municipal Governador Mário Covas Júnior. Ubatuba, SP, vol. 1, 2010.

SETZER, V. W. Meios Eletrônicos e Educação: uma visão alternativa. 3. ed. São Paulo: Escrituras, 2001.

TENÓRIO, R. M. Cérebros e Computadores: a complementaridade analógico-digital na informática e na educação. São Paulo: Escrituras, 1998.

TRÖGER, A. Um estudo sobre organizações virtuais. Disponível em <http://www.inf.ufrgs.br/ palazzo/docs/ti-692.htm> Acesso em 21 dez. 2009.

WIENER, N. Cibernética ou controle e comunicação no animal e na máquina. Gita K. Ghinzberg (trad). São Paulo: Polígono, 1970. 
ANEXO: FOTOS DE VISITA DO PROF. JOSÉ PACHECO À ESCOLA MUNICIPAL GOVERNADOR MÁRIO COVAS JÚNIOR

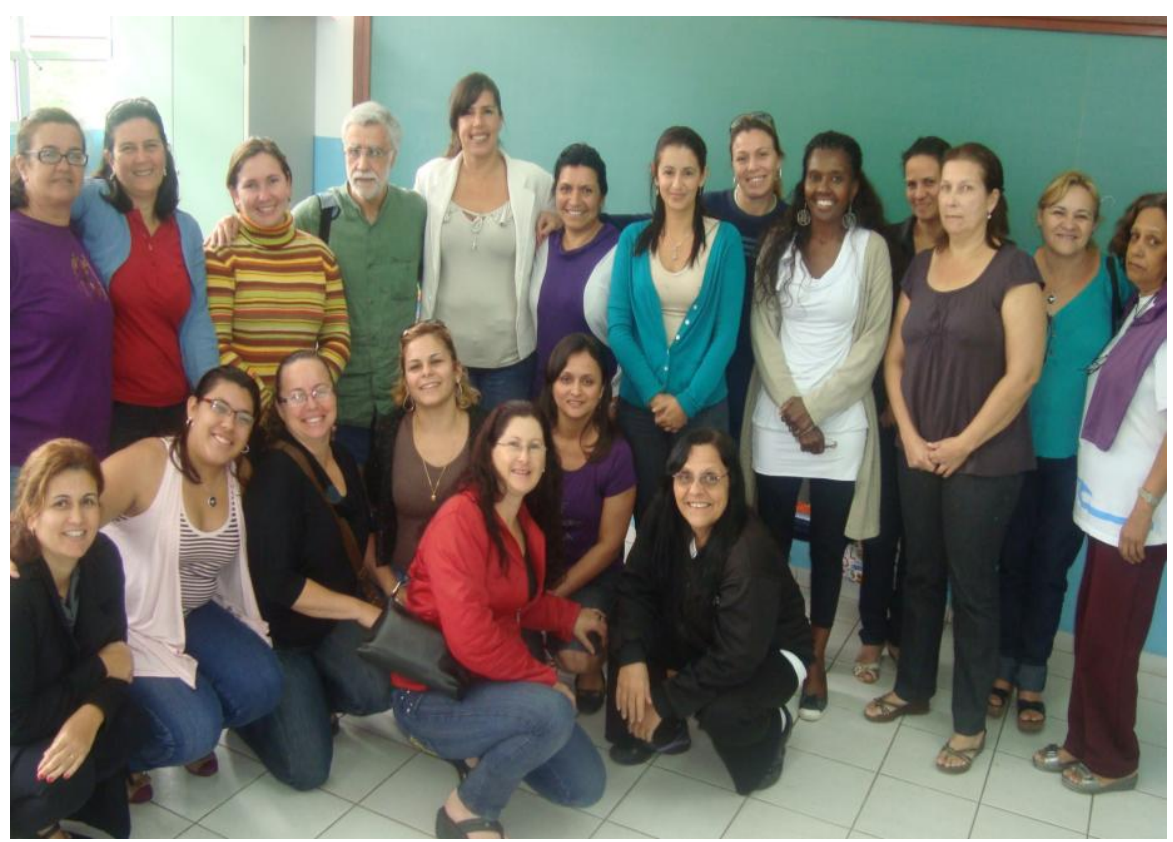

Professoras da E. M. Governador Mário Covas Júnior e Prof. José Pacheco, ao fim de sua entrevista cedida aos profissionais docentes e ao autor da pesquisa

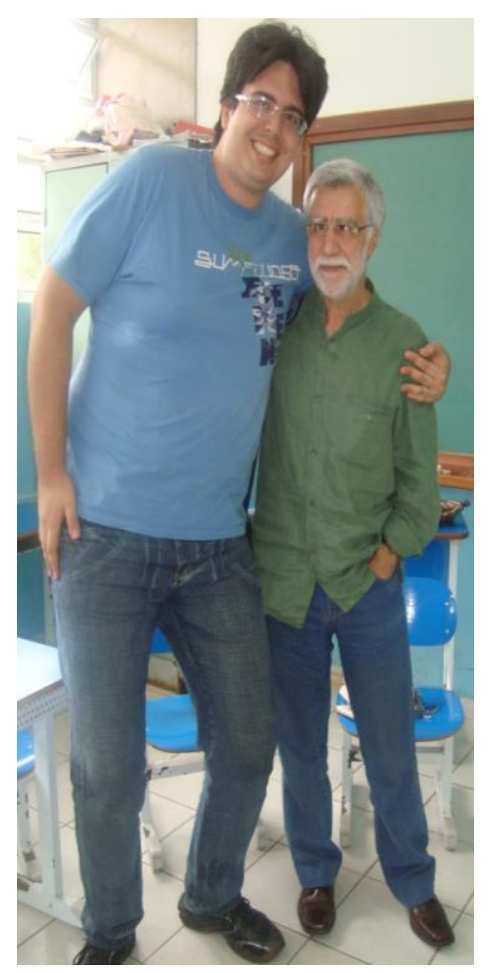

O autor da pesquisa, Carlos Eduardo Damian Leite, junto ao Prof. José Pacheco 


\title{
APÊNDICE A: ENTREVISTA COM PROF. JOSÉ PACHECO (VERSÃO INTEGRAL)
}

\begin{abstract}
A Escola da Ponte é bem diferente das tradicionais. Como ela funciona? Lá não há séries, ciclos, turmas, anos, manuais, testes e aulas. Os alunos se agrupam de acordo com os interesses comuns para desenvolver projetos de pesquisa. Há também os estudos individuais, que são depois compartilhados com os colegas. Os estudantes podem recorrer a qualquer professor tutor para solicitar suas respostas. Se eles não conseguem responder, os encaminhamos a um especialista.
\end{abstract}

Existem salas de aula? Não há salas de aula, e sim lugares onde cada aluno procura pessoas, ferramentas e soluções, testa seus conhecimentos e convive com os outros. São os espaços educativos. Hoje, eles estão designados por área. Na humanística, por exemplo, estudase História e Geografia; no pavilhão das ciências fica o material sobre Matemática; e o central abriga a Educação Artística e a Tecnológica.

A arquitetura mudou para acompanhar o sistema de ensino? Não. Aliás, isso é um problema. Nosso sonho é um prédio com outro conceito de espaço. Temos uma maquete feita por 12 arquitetos, ex-alunos que conhecem bem a proposta da escola. Esse projeto inclui uma área que chamo de "Centro da Descoberta", onde compartilharemos o que sabemos. Há também pequenos nichos hexagonais, destinados aos pequenos grupos e às tarefas individuais. Estão previstas ainda amplas avenidas e alguns cursos d'água, onde se possa mergulhar os pés para conversar, além de um lugar para cochilar. As novas tecnologias da informação devem estar espalhadas por todos os lados, para serem democraticamente utilizadas pela comunidade, o que já conseguimos.

Os professores precisam de formação específica para lecionar lá? Não. Eles têm a mesma formação que os de outras instituições. O diferencial é que sentem uma inquietação quanto à educação e admitem existir outras lógicas. Nossa escola é a única no país que pode escolher o corpo docente. Os candidatos aparecem geralmente como visitantes e perguntam o que é preciso para dar aulas lá. Digo apenas para deixarem o nome. No fim de cada ano fazemos contato. Hoje somos vinte e sete, cada um com suas especializações. 
Como os novos professores se adaptam à proposta da escola? Há profissionais que estiveram sozinhos em sala durante anos e quando chegam constatam que sua formação e experiência servem para nada. De cada dez que entram, um não aguenta. Outros desertam e regressam depois. Mas nós também, por vezes, temos que nos adaptar. Há dois anos recebemos muitas crianças e professores novos, não familiarizados com a nossa proposta. Apenas a quinta parte do corpo docente já estava lá quando isso aconteceu. Passamos a conviver com mestres que sabiam dar aula e estudantes que sabiam fazer cópias. Foi necessário dar dois ou três passos para trás para que depois caminhássemos todos juntos. Precisamos aceitar o que os outros trazem e esperar que eles acreditem em nossas idéias. Essa é a terceira vez que passamos por isso.

Qual o perfil dos alunos atendidos pela Escola da Ponte? Eles têm entre cinco e dezessete anos. Cerca de cinquenta (um quarto do total) chegaram extremamente violentos, com diagnósticos psiquiátricos e psicológicos. As instituições de inserção social que acolhem crianças e jovens órfãos os encaminham para as escolas públicas. Normalmente eles acabam isolados no fundo da classe e, posteriormente, são encaminhados para nós. No primeiro dia, chegam dando pontapés, gritando, insultando, atirando pedras. Algum tempo depois desistem de ser maus, como dizem, e admitem uma das duas hipóteses: ser bom ou ser bom.

Como os estudantes vindos de outras escolas se integram a um sistema tão diferente? Não é fácil. Há crianças e jovens que chegam e não sabem o que é trabalhar em grupo. Não conhecem a liberdade, e sim, a permissividade. Não sabem o que é solidariedade, somente a competitividade. São ótimos, mas ainda não têm a cultura que cultivamos. Quando deparam com a possibilidade de definir as regras de convivência que serão seguidas por todos ou não decidem nada ou o fazem de forma pouco ponderada. Em tempos de crise, como agora, em que muitos estão nessa situação, precisamos ser mais diretivos. Só para citar um exemplo, recebemos um garoto de quinze anos que tinha agredido seu professor e o deixado em estado de coma. Como um jovem assim pode, de imediato, participar da elaboração de um sistema de direitos e deveres?

A escola nem sempre seguiu uma proposta inovadora. Como ocorreu a transformação? Até 1976, a escola era igual a qualquer outra de $1^{\mathrm{a}}$ a $4^{\mathrm{a}}$ série. Cada professor ficava em sua sala, isolado com sua turma e seus métodos. Não havia comunicação ou projeto comum. O trabalho escolar era baseado na repetição de lições, na passividade. Naquele ano, 
havia três educadores e noventa estudantes. Em vez de cada docente adotar uma turma de trinta, juntamos todos. Nosso objetivo era promover a autonomia e a solidariedade. Antes disso, porém, chamamos os pais, explicamos o nosso projeto e perguntamos o que pensavam sobre o assunto. Eles nos apoiaram e defendem o modelo até hoje.

Qual é a relação dos pais com a escola? Eles participam conosco de todas as decisões. Se nos rejeitarem, teremos de procurar emprego em outro lugar. Também defendem a escola perante o governo. Neste momento, os pais estão em conflito com o Ministério da Educação. Ao longo desses quase trinta anos, quiseram acabar com nosso projeto. $\mathrm{Eu}$, como funcionário público, sigo um regime disciplinar que me impede de tomar posições que transgridam a lei, mas o ministro não tem poder hierárquico sobre as famílias. Portanto, se o governo discordar de tudo aquilo que fazemos, defronta-se com este obstáculo: os pais. Eles são a garantia de que o projeto vai continuar.

Como sua escola é vista em Portugal? Há uma grande resistência em aceitar o nosso modelo, que é baseado em três grandes valores: a liberdade, a responsabilidade e a solidariedade. Algumas pessoas consideram que todos precisam ser iguais e que ninguém tem direito a pensamento e ação divergentes. Há quem rejeite a proposta por preconceito, mas isso nós compreendemos porque também temos os nossos. A diferença é que nós nunca colocamos em cheque o trabalho dos outros. Consideramos que quem nos ataca faz isso porque não foi nosso aluno e não aprendeu a respeitar o ponto de vista alheio.

Qual é o segredo de sucesso da proposta seguida pela Ponte? Nós acreditamos que um projeto como o nosso só é viável quando todos reconhecem os objetivos comuns e se conhecem. Isso não significa apenas saber o nome, e sim ter intimidade, como em uma família. É nesse ponto que o projeto se distingue. O viver em uma escola é um sentimento de cumplicidade, de amor fraterno. Todos que nos visitam dizem que ficam impressionados com o olhar das pessoas que ali estão, com o afeto e a palavra terna que trocam entre si. Não sei se estou falando de educação ou da minha escola, mas é isso o que acontece lá.

O modelo da Escola da Ponte pode ser seguido por outras escolas? Não defendo modelos. A (Escola da) Ponte fez o que as outras devem e podem fazer, que é produzir sínteses e 
não se engajar em um único padrão. Não inventamos nada. Estamos em um ponto de redundância teórica. Há muitas correntes e quem quer fazer diferente tem de ter mais interrogações do que certezas. Considero que na educação tudo já está inventado. A Escola da Ponte não é duplicável e não há, felizmente, clonagem de projetos educacionais. No caso da Escola Municipal Mário Covas, a ideia de adotar ideias e práticas pedagógicas da Ponte não deve ser considerado cópia de uma instituição exemplar, mas antes uma troca de ideias, em busca da formação de um aluno criativo, reflexivo e crítico.

Hoje a escola pode funcionar sem o senhor? Fui e continuo sendo um intermediário. Não tenho mérito por isso, apenas cumpro a minha missão. Vou me afastar dentro de um ano e estou amargamente antecipando essa despedida. Todo pai tem de deixar o filho andar por si próprio e, nesse momento, a Ponte caminha sozinha. Depois quero continuar desassossegando os espíritos em lugares onde há gente generosa, que só precisa de um louco com a noção da prática, como eu. Agora ninguém pode dizer que uma experiência como a da Escola da Ponte não aconteceu, porque ela existe e provamos que é possível. 


\section{APÊNDICE B: MODELO DE TERMO DE CONSENTIMENTO LIVRE E ESCLARECIDO}

Prezado (a) Professor (a):

O (a) senhor (a) está sendo convidado (a) a participar, como voluntário, de uma pesquisa realizada como coleta de dados para a elaboração de uma dissertação, requisito para conclusão do Mestrado em Educação na Faculdade de Educação da Universidade de São Paulo, cujo objetivo é verificar suas percepções acerca do conceito de virtualidade, bem como sobre o uso das novas tecnologias, suas opiniões e conhecimentos sobre esta área. Para tanto, lhe será solicitado responder um questionário com questões abertas, que se caracterizará como coleta de dados da pesquisa em questão. Informa-se ainda que este procedimento não oferece risco algum à integridade física ou moral dos participantes, bem como despesas, prejuízos ou benefícios diretos. Sua participação é voluntária e sigilosa, sendo os dados coletados exclusivos para uso nesta pesquisa, sendo permitida a retirada do consentimento a qualquer momento, sem qualquer ou punição ao participante. Após ser esclarecido (a) sobre as informações a seguir, no caso de aceitar fazer parte do estudo, assine ao final do documento, que está em duas vias. Uma delas é sua e outra a do pesquisador responsável. Em caso de recusa, o (a) senhor (a) não será penalizado (a) de forma alguma. Quaisquer dúvidas poderão ser esclarecidas com o próprio pesquisador.

Obrigado por sua colaboração!

\section{INFORMAÇÕES SOBRE A PESQUISA:}

Titulo da dissertação: A virtualidade na mediação simbólica e na linguagem sob o ponto de vista docente na aprendizagem

Pesquisador Responsável: Carlos Eduardo Damian Leite

Prof. ${ }^{a}$ Orientadora: Dr. ${ }^{a}$ Nilce da Silva

Telefone para contato: (12) 3833-6121/9217-3693 


\title{
APÊNDICE C: MODELO DE SONDAGEM
}

QUESTIONÁRIO QUANTITATIVO - E. M. Governador Mário Covas Júnior

\section{USO DAS TECNOLOGIAS DIGITAIS}

\author{
Formação:
}

Ano (s) e disciplina (s) nas quais leciona:

Você utiliza as novas tecnologias em seu cotidiano? ( ) Sim ( ) Não

Você possui conhecimentos básicos em informática? ( ) Sim ( ) Não

Cite três programas (softwares) que você utiliza em seu cotidiano pessoal e profissional, inclusive no preparo de suas aulas:

Cite três programas (softwares) utilizados em suas aulas, que são preferidos por seus alunos também no uso diário do computador: 


\title{
APÊNDICE D: MODELO DE QUESTIONÁRIO COM QUESTÕES ABERTAS
}

\author{
A VIRTUALIDADE NO AMBIENTE PEDAGÓGICO
}

\section{ESTUDO DE CASO: E. M. GOVERNADOR MÁRIO COVAS JÚNIOR}

Nome do(a) professor(a):

Ano(s) para o(s) qual(is) leciona:

Disciplina(s):

1) A constante evolução e inovação das novas tecnologias propõem não apenas uma nova maneira de lidar com o saber, mas também de administrá-lo em um contexto diferenciado: o virtual. E para você, o virtual no desenvolvimento intelectual e cultural está restrito apenas ao uso das novas tecnologias, como computadores, a Internet, videogames, celulares e outros recursos digitais?

2) Aristóteles, em suas concepções filosóficas, diz que o virtual é uma característica mental e psicológica do ser humano, chamada virtualidade, pela qual ele planeja suas ações e idealiza o seu potencial para o futuro. Em sua opinião, é possível a existência do virtual independentemente das novas tecnologias?

3) Para alguns autores, o ambiente virtual das novas tecnologias é uma extensão da imaginação humana, tornando visível o que é elaborado há tempos pela mente. Diante desta afirmação, comente o uso para com as novas tecnologias em relação a sua disciplina, assim como o que você acha do virtual e de que modo ele influencia os alunos em diferentes aspectos (social, cultural e /ou pedagógico).

4) Você considera o virtual como um recurso para potencializar a interdisciplinaridade, nas atividades que envolvem o uso dos computadores? E fora do ambiente escolar, você sabe e/ou reconhece algo em relação a uma melhor compreensão e utilização das novas tecnologias por parte dos alunos, a partir do que aprendem na escola?

5) Em relação à virtualidade, tal qual a oportunidade de projetar e potencializar ações e atitudes, considere o modo como planeja suas aulas: como você relaciona este 
planejamento com as duas concepções de virtual (filosófica e tecnológica)? Em um momento anterior, ao imaginar as realizações em sala, como as ações são projetadas para com a(s) classe(s), em relação aos alunos, aos conteúdos e recursos didáticos? 


\title{
APÊNDICE E: TERMO DE CONSENTIMENTO LIVRE E ESCLARECIDO PARA DIVULGAÇÃO DAS INFORMAÇÕES DA INSTITUIÇÃO DO ESTUDO DE CASO
}

\author{
Prezadas Diretora e Vice Diretora da E. M. Mário Covas
}

Por meio deste termo de consentimento livre e esclarecido, venho solicitar permissão para a coleta de dados para a elaboração de uma dissertação, requisito para conclusão do Mestrado em Educação na Faculdade de Educação da Universidade de São Paulo, cujo objetivo é verificar suas percepções acerca do conceito de virtualidade, bem como sobre o uso das novas tecnologias, suas opiniões e conhecimentos sobre esta área. Para tanto, serão realizadas observações voltadas às aulas e demais atividades curriculares, bem como uma sondagem quantitativa e um questionário com questões abertas, que também servirão para a coleta de dados da pesquisa em questão. Informa-se ainda que este procedimento não oferece risco algum à integridade física ou moral dos participantes, bem como despesas, prejuízos ou benefícios diretos. Os dados serão divulgados de forma sigilosa, sendo coletados para uso exclusivo nesta pesquisa, sendo permitida a retirada do consentimento a qualquer momento, sem qualquer ou punição ao participante. Após ser esclarecido (a) sobre as informações a seguir, no caso de aceite desta permissão, peço a assinatura de uma das gestoras ao final do documento, que está em duas vias. Uma delas é da instituição e outra a do pesquisador responsável. Em caso de recusa, não haverá qualquer penalidade. Quaisquer dúvidas poderão ser esclarecidas com o próprio pesquisador.

\section{INFORMAÇÕES SOBRE A PESQUISA:}

Titulo da dissertação: A virtualidade na mediação simbólica e na linguagem sob o ponto de vista docente na aprendizagem

Pesquisador Responsável: Carlos Eduardo Damian Leite

Prof. ${ }^{a}$ Orientadora: Dr. ${ }^{\text {a }}$ Nilce da Silva

Telefone para contato: (12) 3833-6121/9217-3693 